Entwicklung und Validierung eines ELISA zur Beurteilung der Tetanusvakzinierung am Beispiel eines Pferdebestandes in Thüringen

\author{
Dissertation \\ zur Erlangung des Doktorgrades \\ der Fakultät für Agrarwissenschaften \\ der Georg-August-Universität Göttingen \\ vorgelegt von \\ Anke Jutta Mülverstedt \\ geboren in Mühlhausen/Thüringen
}

Göttingen, Februar 2006 
$\underline{\mathrm{D} 7}$

1. Referent: Prof. Dr. med. vet. Dr. sc. agr. habil. Helge Böhnel

2. Korreferent: Prof. Dr. med. vet. Dr. med. vet. habil. Claus-Peter Czerny

Tag der mündlichen Prüfung: 02. Februar 2006 


\section{Verzeichnis der Abkürzungen}
Abb.
Abbildung
a. p.
ante partum
$\mathrm{a}_{\mathrm{w}}$-Wert
Wasseraktivität
B.
Genus Bacillus
bp
Basenpaare
BSA
bovines Serumalbumin (Fraktion V)
bzw.
beziehungsweise
C.
Genus Clostridium
DNA
Desoxyribonukleinsäure
E. coli
Escherichia coli
ECVAM
European Centre for the Validation of Alternative Methods
EDTA
Ethylendiamintetraessigsäure
ELISA
Enzyme Linked Immunosorbent Assay
fzmb
Forschungszentrum für Medizintechnik und Biotechnologie e. V.
GABA
$\gamma$-Aminobuttersäure
G+C-Gehalt
Guanin-Cytosin-Gehalt
HIV
Human Immunodeficiency Virus
H-Kette
schwere Kette (des Tetanustoxins)
HRP
Meerrettichperoxidase
IE
Internationale Einheit
$\operatorname{Ig} \mathrm{A}$
Immunglobulin A
$\operatorname{IgE}$
Immunglobulin $\mathrm{E}$
IgG
Immunglobulin $\mathrm{G}$
$\operatorname{Ig} \mathrm{M}$
Immunglobulin $\mathrm{M}$
L.
Genus Lactobacillus
$\mathrm{LD}_{50}$
Dosis einer verabreichten Substanz, bei der 50 \% der Versuchstiere in einer bestimmten Zeit sterben
Lf
Ausflockungseinheit
L-Kette
leichte Kette (des Tetanustoxins)
MG
Molekülmasse
MFA
Multiplex Fluoreszenzassay
N.
Nervus 


\begin{tabular}{|c|c|}
\hline NIBSC & National Institute for Biological Standards and Control \\
\hline NEM & N-Ethylmaleinamid \\
\hline NN & Normalnull \\
\hline NSF & NEM sensitive Fusionsproteine \\
\hline NT & Neutralisationstest \\
\hline OIE & World Organization for Animal Health \\
\hline OPD & Orthophenyldiamin \\
\hline PBS & Phosphatpuffer \\
\hline PCR & Polymerasekettenreaktion \\
\hline PHA & passiver Hämagglutionationshemmtest \\
\hline Ph. Eur. & Europäisches Arzneibuch \\
\hline PMSG & Pregnant Mare Serum Gonadotropin \\
\hline p. p. & post partum \\
\hline RIVM & Reichsinstitut für Volksgesundheit und Umwelt, Bilthoven (NL) \\
\hline RKI & Robert-Koch-Institut \\
\hline RT & Raumtemperatur \\
\hline S. & Genus Saccharomyces \\
\hline SIgA & Sekretorisches IgA \\
\hline SNAP & lösliche NSF-Attachement Proteine \\
\hline SNARE & SNAP-Rezeptor \\
\hline Tab. & Tabelle \\
\hline TeNT & Tetanusneurotoxin $=$ Tetanospasmin \\
\hline TetC & Fragment $\mathrm{C}$ des Tetanusneurotoxins \\
\hline ToBi & Toxinbindungsinhibitionstest \\
\hline UV & Ultraviolett \\
\hline V. & Vena \\
\hline VAMP & vesikelassoziiertes Membranprotein (Synaptobrevin) \\
\hline WHO & Weltgesundheitsorganisation \\
\hline ZNS & Zentralnervensystem \\
\hline
\end{tabular}


$1 \quad$ Einleitung und Zielsetzung $\quad 9$

2 Literaturübersicht 12

2.1 Clostridium tetani - Historie und Taxonomie 12

2.2 Morphologie, Kultur und Genetik 13

$\begin{array}{lll}2.3 & \text { Tetanus } & 17\end{array}$

$\begin{array}{ll}\text { 2.3.1. Pathogenese, Klinik und Therapie } & 17\end{array}$

2.3.2. Epidemiologie 20

$\begin{array}{lll}2.4 & \text { Toxine } & 21\end{array}$

2.4.1. Tetanospasmin 21

2.4.2. Tetanolysin 23

2.5 Immunologie 23

2.5.1 natürlich erworbene Immunität 25

2.5.2 künstlich erworbene Immunität 25

$\begin{array}{ll}\text { 2.5.3 Immunglobuline } & 27\end{array}$

2.5.3.1 IgG 28

2.5.3.2 IgM 28

2.5.3.3 IgA 28

2.5.3.4 IgE 29

$2.6 \quad$ Vakzinierung 29

2.6.1 Aktive Immunisierung und Impfstoffentwicklung 29

2.6.2 Passive Immunisierung 32

2.7 Nachweismethoden 33

2.7.1 Direkter Erregernachweis 33

2.7.2 in vivo-Neutralisationstest 33

2.7.2.1 Toxinbestimmung aus Untersuchungsmaterial 34

2.7.2.2 Challengetest zur Impfstoffkontrolle 34

2.7.3 Passive Hämagglutination 34

2.7.4 Toxinbindungsinhibitionstest 35

$\begin{array}{lll}2.7 .5 & \text { ELISA } & 35\end{array}$

2.7.6 Radioimmunoassay 36

$\begin{array}{lll}2.7 .7 & \text { Fluoreszenzassay } & 37\end{array}$

2.7.8 Latexagglutination und Gelfiltrationstechniken 37 
$3 \quad$ Materialien und Methoden 38

3.1 Allgemeine Angaben über das Untersuchungsgebiet 38

3.1 Geografische und ackerbauliche Parameter des Untersuchungsgebietes 38

3.1.3 Haltungszweck der Untersuchungstiere 39

3.1.4 Haltung und Fütterung 39

3.2 Blutentnahme; Aufbereitung und Rekonstitution der Blutproben 40

3.3 Gewinnung der Milchproben; Aufbereitung und Rekonstitution der Milchproben 40

$3.4 \quad$ Vakzinierung 41

$3.5 \quad$ Statistische Auswertung 41

$4 \quad$ ELISA $\quad 42$

4.1 Materialien und Methoden Serum/Plasma-ELISA 42

4.1.1 Konzeption 42

4.1.2 Coaten und Blocken der Mikrotiterplatten 42

4.1.3 Durchführung des ELISA 42

4.1.4 Erstellung der Standardkurve und des Algorhythmus 43

4.1.4.1 Verwendung von Toxin 43

4.1.4.2 Verwendung von Toxoid 43

4.1.5 Prüfung auf Verwendbarkeit von Serum und Plasma mit 43 verschiedenen Antikoagulanzien

4.1.6 Ermittlung der optimalen Serumverdünnung 44

4.1.7 Ermittlung des Variationskoeffizienten, der Intraassay- und 44 Interassayvarianz

4.1.8 Prüfung auf Kreuzreaktionen 44

4.1.9 Ermittlung des Cut off und des Schwellenwertes 45

4.1.10 Bestimmung der Sensitivität 45

4.2 Materialien und Methoden Kolostrum/Milch-ELISA 46

4.2.1 Konzeption 46

4.2.2 Coaten und Blocken 46

4.2.3 Durchführung 46

$\begin{array}{lll}4.3 & \text { Ergebnisse } & 47\end{array}$

$\begin{array}{lll}\text { 4.3.1 Blut-ELISA } & 47\end{array}$

4.3.1.1 Toxinstandardkurve $\quad 47$

4.3.1.2 Toxoidstandardkurve $\quad 47$

4.3.1.3 Verwendbarkeit von Serum- und Plasmaproben 48 
4.3.1.4 Ermittlung der optimalen Serumverdünnung 48

4.3.1.4 Intraassayvarianzkoeffizient 49

4.3.1.5 Interassayvarianzkoeffizient $\quad 50$

4.3.1.6 Prüfung auf Kreuzreaktionen $\quad 50$

4.3.1.7 Bestimmung des Cut off und des Schwellenwertes 50

4.3.1.8 Bestimmung der Sensitivität $\quad 51$

4.3.2 Milch-ELISA - Konzeption und Durchführung 52

4.4 Diskussion $\quad 53$

4.4.1 Blut-/Serum-ELISA 53

$\begin{array}{lll}\text { 4.4.2 } & \text { Milch-ELISA } & 58\end{array}$

4.4.3 Korrelation zwischen Blut- und Milch-ELISA 59

5 Felduntersuchungen 60

$\begin{array}{lll}5.1 & \text { Materialien und Methoden } & 60\end{array}$

$\begin{array}{lll}\text { 5.1.1 Untersuchungsgruppen } & 60\end{array}$

5.1.2 Verlauf des maternalen tetanusspezifischen IgG-Gehaltes im Serum 60 neugeborener Fohlen

5.1.3 Titerverauf bei einjährigen Jungstuten vor und nach Tetanusgrund- 61 immunisierung

5.1.4 Titerverlauf bei Saugfohlen nach Tetanusgrundimmunisierung 61

5.1.5 Titerverlauf immunisierter Altstuten nach Boosterung 62

5.1.6 Verlauf des tetanusspezifischen IgG-Gehaltes in Kolostrum und Milch 62

5.1.7 Titerverlaufkontrolle bei einem an Tetanus erkrankten 62 Fohlen

5.2 Ergebnisse $\quad 64$

5.2.1 Verlauf des maternalen tetanusspezifischen IgG-Gehaltes im Serum 64 neugeborener Fohlen

5.2.2 Titerverauf bei einjährigen Jungstuten nach Tetanusgrundimmunisierung 65

5.2.3 Titerverlauf bei Saugfohlen nach vollständiger Grundimmunisierung 67

5.2.4 Titerverlauf immunisierter Altstuten nach Boosterung 70

5.2.5 Verlauf des tetanusspezifischen IgG-Gehaltes in Kolostrum und Milch 71

5.2.6 Vergleich der Tetanus-Antitoxin-Titer in Kolostrum/Milch und 73 Stutenserum mit den Serumgehalten der Fohlen

5.2.7 Titerverlaufkontrolle bei einem an Tetanus erkrankten Fohlen 75 
$\begin{array}{lll}5.3 & \text { Diskussion } & 76\end{array}$

5.3.1 Antitoxingehalt im Fohlenserum 76

5.3.2 Titerverlauf nach Grundimmunisierung bei Saugfohlen 77

$\begin{array}{lll}\text { 5.3.3 Titerverlauf von Altstuten nach Boosterung } & 79\end{array}$

5.3.4 Antitoxintiterentwicklung bei Jährlingen 79

5.3.5 Antitoxingehalte in Stutenkolostrum und Milch 81

$\begin{array}{lll}\text { 5.3.6 Fallbeispiel } & 82\end{array}$

6 Zusammenführende Diskussion und Schlussfolgerungen 84

6.1 Zusammenführende Diskussion 84

$\begin{array}{lll}6.2 & \text { Schlussfolgerungen } & 86\end{array}$

7 Zusammenfassung 88

8 Summary 89

9 Literaturverzeichnis 90

Anhang

I Geräte und Chemikalien und Puffer

II Tabellenverzeichnis

III Abbildungsverzeichnis 


\section{$1 \quad$ Einleitung und Zielsetzung}

Tetanus ist eine der ältesten dokumentierten und gefürchtetsten Erkrankungen bei Menschen, Pferden und Ruminanten. Bis in die heutige Zeit fordert Tetanus besonders in entwicklungsschwachen Ländern Asiens, Afrikas und Lateinamerikas viele Opfer unter der zumeist armen Bevölkerung. Auf Grund der extrem hohen Empfindlichkeit der Equiden gegenüber TeNT (Tetanustoxin) spielt diese Erkrankung auch in der Veterinärmedizin eine Rolle. Erkranken können praktisch alle Individuen empfänglicher Spezies, unabhängig von Alter, Geschlecht oder beim Menschen auch sozioökonomischen Status. Bei Pferden können die Haltungsbedingungen eine Rolle spielen. Die Einführung der Tetanusvakzinierung in der Human- und Veterinärmedizin hat die Erkrankung in den letzten Jahrzehnten in den Industrieländern in den Hintergrund gerückt.

Die Infektion geht in der Regel von einer Primärverletzung oder einer Infektion über den Nabelschnurstumpf Neugeborener aus. Sporen von C. tetani aus kontaminierten Böden, Staub oder Schmutz können unter anaeroben Bedingungen im Wundgebiet auskeimen. In Folge kommt es zur Sezernierung verschiedener Pathogenitäts- und Virulenzfaktoren durch $C$. tetani. Für das charakteristische Krankheitsbild des Tetanus ist Tetanospasmin ( Tetanustoxin) verantwortlich. Tetanospasmin ist, nach Botulinumtoxin, das zweitstärkste bekannte bakterielle Toxin. Nach Bindung an motorische Neuronen wandert Tetanospasmin durch axoplasmatischen Transport zum Zentralnervensystem. Die tetanustoxinvermittelte Inhibition der vesikelassoziierten Endozytose leitet die Erkrankung ein. In Folge treten schmerzhafte tonisch-klonische Krämpfe der ventralen Muskulatur auf. Erkrankte können fallen und festliegen. Weitere neuronale Ausfallerscheinungen wie Trismus und Risus sardonicus können beobachtet werden. Das Bewusstsein bleibt ungetrübt. Die Letalität beträgt auch unter Intensivtherapie 50-80\%.

Der direkte Toxinnachweis ist für die Diagnosestellung von untergeordneter Bedeutung. Er dient zur Beweisführung sowie der Klärung epidemiologischer Ketten und Zusammenhänge. Die Referenzmethode zur Toxinbestimmung ist der in vivo-Maus-Neutralisationstest.

Durch die extrem hohe Toxizität des Tetanospasmins nimmt die Entwicklung und Kontrolle leistungsfähiger potenter Impfstoffe einen zunehmenden Stellenwert ein. Impfchargen für die Human- und Veterinärmedizin werden in autorisierten Instituten nach verbindlichen 
Qualitätsstandards hinsichtlich qualitativer und quantitativer Zusammensetzung sowie biologischer Sicherheit überprüft.

Die Kontrolle von Impfstoffen wird mit dem Maus-/Meerschweinchen-Challengetest durchgeführt. Wie alle anderen Tierversuche ist auch der Challengetest mit streng restriktiven Bestimmungen assoziiert. In den vergangenen Jahren wurden weltweit Anstrengungen unternommen, eine in vitro-Ersatzmethode zu entwickeln, um der Forderung von WHO und ECVAM zur Einsparung von Tieren für Versuchszwecke im Sinne des Tierschutzes zu entsprechen.

Im Gegensatz zu vielen der bisher entwickelten in vitro-Assay besitzt die in vivo-Methode eine herausragende Sensitivität. Insbesondere niedrigtitrige Seren können mit dieser Methode zuverlässig bestimmt werden. Der protektive Tetanustiter wird methodenabhängig angegeben. Der protektive tetanusspezifische Titer für Menschen bei Testung mit der in vivo-Methode wird mit 0,01 IU/ml angegeben. Dieser Wert entspricht 0,1 IU/ml im ELISA (WHO 1995).

Ziel der vorliegenden Arbeit war die Entwicklung eines in vitro-Verfahrens auf Basis eines ELISA zur Bestimmung des Antikörpergehaltes gegen Tetanustoxin bei Pferden. Da eine natürliche Immunität gegen C. tetani nahezu ausgeschlossen wird, kommt auch in der Pferdemedizin der Überprüfung der Vakzinierungsstrategie besondere Bedeutung zu. Im Gegensatz zur Humanmedizin existieren in der Veterinärmedizin noch keine allgemeinen Richtlinien zur Definition schützender bzw. grenzwertiger Anti-Tetanus-Titer.

Folgende Schwerpunkte sollten in dieser Arbeit betrachtet werden:

- Entwicklung eines in vitro-Tests zur Bestimmung des Antikörpergehaltes tetanustoxoidimmunisierter erwachsener Pferde

- Adaptation des Tests zur Bestimmung von Tetanus-IgG in Kolostrum und Milch

- Erfassung, Verfolgung und Bewertung des maternalen passiven Schutzes neugeborener Fohlen anhand des Antikörpergehaltes im Serum ihrer Mütter

- Einfluss der Aufnahme von tetanusspezifischen Antikörpern durch Kolostrum und reife Milch auf den serumspezifischen Antikörpergehalt von Saugfohlen

- Partizipierung von Cut off und Schwellenwert durch Bestimmung des tetanusspezifischen Antikörpergehaltes primär nichtimmunisierter Jährlinge 
- Titerverlaufkontrollen bei primär nicht vakzinierten Jährlingen sowie bei 3-4 Monate alten Absatzfohlen vor und nach Beginn der Grundimmunisierung

- Bestimmung der tetanusspezifischen Antikörpertiter eines an Tetanus erkrankten Pferdes. 


\section{$2 \quad$ Literaturübersicht}

\subsection{Clostridium tetani - Historie und Taxonomie}

Tetanus oder Wundstarrkrampf ist eine seit dem Altertum bekannte Erkrankung. Bereits im 3.-4. Jahrhundert vor Christus wurde das Krankheitsbild im Corpus hippocratium beschrieben (zit. von Bizzini, 1979). Der Göttinger Mediziner NICOLAIER (1884) entdeckte die direkte Kausalität zwischen Wundinfektion und Tetanus. Nach künstlicher Infektion von Versuchstieren mit Erdproben isolierte er die Bakterien aus deren Wunden. 1889 züchtete KITASATO C. tetani erstmals in Reinkultur auf künstlichen Medien (Pitzurra, 1989). Im Jahr 1890 gelang FABER, KITASATO und von BEHRING der Toxinnachweis durch Auslösung der Krankheitssymptome nach Injektion eines Kulturüberstandes von C. tetani in Mäusen. Im gleichen Jahr haben FABER, v. BEHRING und KITASATO erstmals antitoxisches Tetanusserum durch Immunisierung von Pferden und Kaninchen gewonnen (Brandis et al., 1994).

Clostridien zählen zur Gattung der Bacillaceae, endosporenbildender grampositiver Stäbchen (Bergey, 1968). Neben verschiedenen Gärungs- und Fäulnisserrregern gehören zur Gattung Clostridium wichtige Krankheitserreger, die durch Exotoxinbildung Toxoinfektionen bzw. Intoxikationen hervorrufen können. Der Metabolismus der Clostridien ist anaerob. AKULINICHEWA (1989) beschrieb aerotolerante C. tetani-Stämme, die unter Sauerstoffanwesenheit sowohl ihre Vitalität, als auch ihr Toxinbildungsvermögen behielten. Einige Arten erscheinen durch peritriche Begeißelung beweglich. Das morphologische Hauptmerkmal der Clostridien ist die Bildung von Endosporen, die den Bakterien ihr charakteristisches Äußeres verleiht. Die terminalliegenden, ovalen Sporen geben C. tetani ihr trommelschlegelartiges Aussehen. Der optimale pH-Wert für das Wachstum der Clostridien schwankt zwischen 6,5-7,0. Ihre optimale Wachstumstemperatur liegt in der Regel zwischen $30-40{ }^{\circ} \mathrm{C}$. Thermophile Clostridien können sich über einen Bereich von $60-75^{\circ} \mathrm{C}$ vermehren (Schlegel, 1981). Das Temperaturoptimum von C. tetani ist $37^{\circ} \mathrm{C}$. Durch peritriche Begeißelung ist C. tetani stark beweglich. Nach Sauerstoffzutritt kann die Beweglichkeit eingeschränkt sein (Lindner, 1971).

Ihre Größe variiert zwischen 2,4-5 $\mu \mathrm{m}$ und 0,5-1,1 $\mu \mathrm{m}$ (Seifert und Böhnel, 1995). Clostridien imponieren im mikroskopischen Präparat als gerade oder leicht gebogenen 
Stäbchen, die sowohl einzeln, als auch in Paaren oder in mehr oder weniger langen Fäden vorliegen können. C. tetani erscheint im mikroskopischen Präparat als etwa 4-8 $\mu$ m langes und ca. 0,5 $\mu \mathrm{m}$ dickes Stäbchen. Während der lag-Phase und der initialen exponentiellen Phase sind Kulturen von C. tetani grampositiv. In älteren Kulturen ist C. tetani gramlabil bis gramnegativ (Beveridge, 1990).

Die meisten Clostridium-Arten leben chemo-organotroph, einige chemolithotroph bzw. chemoorganotroph. SCHLEGEL (1981) unterscheidet die Clostridien nach ihren bevorzugten Substratgruppen in saccharolytische Clostridien (C. butyricum, C. acetobutylicum), PeptoClostridien (C. histolyticum, C. tetani, C. sporogenes, C. botulinum) und harnsäurezersetzende Clostridien (C. acidi-urici). Clostridien besitzen einen ausgeprägten Gärungsstoffwechsel. Endprodukte sind vor allem Butyrat, Butanol, Aceton, 2-Propanol sowie oft große Mengen Gas $\left(\mathrm{H}_{2}, \mathrm{CO}_{2}\right)$. Clostridien sind in der Regel nicht zur Bildung von Häm-Derivaten (Katalase, Oxidase) befähigt. Einige Arten können Zytochrome bilden. Das Redoxsystem der Clostridien besteht aus Eisen-Schwefelproteinen [4Fe+4S] oder 2[4 Fe+4S], die durch eine niedrige relative Molekülmasse und ein stark negatives Redoxpotential gekennzeichnet sind. Als Speicherstoffe dienen Polysaccharide. Ihre Zellwand enthält mesoDiaminopimelinsäure (Schlegel, 1981).

\subsection{Morphologie, Kultur und Genetik}

C. tetani ist ein Bodenbewohner der gemäßigten und tropischen Regionen. Daneben findet man Tetanusbakterien in Straßenstaub, tierischen und pflanzlichen Abfällen und in den Sedimenten der Ozeane. Ein häufiges Habitat ist der Magen-Darm-Trakt bei Herbivoren und Omnivoren (Umesaki et al., 1999).

Auf Grundlage der H-Antigenstruktur lassen sich 9 Serotypen von C. tetani unterscheiden. Zusätzlich tritt ein geißelloser Typ IV auf. Allen 10 Serotypen ist das O-Antigen gemein, das zur fluoreszenzmikroskopischen Identifizierung genutzt wird. Bei allen Serotypen kommen nichttoxinbildende Stämme vor. Sporenantigene sind speziesspezifisch und nicht mit den Ooder H-Antigenen verwandt (Brandis et al., 1994).

Die Anzucht gelingt auf komplexen Nährböden in anaeroben Milieu (Kaufman und Humphries, 1958). Dabei sind Tryptophan, Adenin und Panthothensäure essentiell für das 
Wachstum von C. tetani (Mueller und Miller, 1941). C. tetani ist auf Natrium-EisenBioenergie angewiesen (Perego et al., 2004).

Bei der Bearbeitung von klinischem Material kann die Probe zur Unterdrückung der Begleitflora für 15 min auf $80^{\circ} \mathrm{C}$ erhitzt werden. Der kulturelle Nachweis aus Wundmaterial gelingt nur selten. Auf supplementierten Blutplatten bilden sich zarte flache farblose Kolonien mit ausgefranstem Rand und Ausläufern. Teilweise können sie als feiner Rasen schwarmartig über die gesamte Nährbodenoberfläche wachsen. Hämolyse wird nur bei Einzelkolonien beobachtet (Lindner, 1971).

Die biochemische Aktivität von C. tetani ist allgemein gering (Tab. 1). Es ist zytochromoxidase- und katalasenegativ. Entgegen der allgemeinen Annahme, dass C. tetani ein nichtsaccharolytischer Organismus ist, wiesen MARTINEZ und RITTENBERG (1958) aktive Glukosedissimilation im Anschluss an die log-Phase nach.

\begin{tabular}{|c|c|}
\hline Parameter & Leistung \\
\hline DNAse & $(+)$ \\
Fibrinolysin & $(+)$ \\
Galaktose & - \\
Gelatinase & $(+)$ \\
Glukose & - \\
$\mathrm{H}_{2} \mathrm{~S}$ & + \\
Indol & + \\
Lezithinase & - \\
Lipase & - \\
Maltose & - \\
Milchgerinnung & + \\
Saccharose & - \\
Salicin & - \\
\hline
\end{tabular}

Abb. 1: Biochemisches Profil von C. tetani (Brandis et al., 1994)

Die Endprodukte des Substratabbaus im Pepton-Hefeextrakt-Medium sind Essigsäure, Buttersäure, Propionsäure, Ethylalkohol und Buthylalkohol.

Fortschreitende Kulturzeit von C. tetani hat eine zeitabhängige Veränderung der Zellwandstruktur zur Folge, die sich in unterschiedlichem Gramverhalten äußert. Elektronenoptische Studien zeigten Veränderungen der Wandstruktur bei Anstieg der Verdopplungszeit (log-Phase). Die Schicht unter dem sogenannten S-Layer wird dünner und diffuser. Die Abnahme der Peptidoglycanschicht korreliert mit der Zunahme der Gramnegativität (Beveridge, 1990). 
Die weltweite Verbreitung des Tetanuserregers ist in hohem Maße auf die Umweltresistenz seiner Dauerformen zurückzuführen. Im Gegensatz zu den vegetativen Formen zeichnen sich Endosporen durch eine hohe Tenazität gegenüber Umwelteinflüssen und Desinfektionsmaßnahmen aus. Die Inaktivierung von Clostridiensporen um 5-6 log-Stufen gelang nur mit hohem Druck und hoher Temperatur über 400 MPa für 10-30 min bei 70-110 ${ }^{\circ} \mathrm{C}$ (Kalchayanand et al., 2004). Eine vergleichende Darstellung zwischen den vegetativen Formen und Sporen von C. tetani ist in Tabelle 2 wiedergegeben.

\begin{tabular}{|c|c|c|}
\hline Parameter & Vegetative Form & Endosporen \\
\hline Temperatur & $3-45^{\circ} \mathrm{C}$; Optimum $37^{\circ} \mathrm{C}$ & $\begin{array}{l}\text { Überleben } 100^{\circ} \mathrm{C} \text { mehrere } \\
\text { Stunden; } 70^{\circ} \mathrm{C} \\
\text { (Kompostierung, Silierung, ..) } \\
\text { ohne Einfluss }\end{array}$ \\
\hline pH-Wert & 5,0-7,5; Optimum 7,0 - 7,4 & $\begin{array}{l}\text { Verkürzung der Absterberate } \\
\text { in alkalischem Milieu }\end{array}$ \\
\hline Redoxpotential & $\begin{array}{l}\text { In Abhängigkeit vom pH- } \\
\text { Wert; +30 mV-250 mV }\end{array}$ & Kein Auskeimen > +250 mV \\
\hline$A_{w}$-Wert & $\begin{array}{l}\text { Essentiell für Nährstoff- } \\
\text { diffusion, Metabolit- und } \\
\text { Sauerstofftransport }\end{array}$ & $\begin{array}{l}\text { Überleben Austrocknung für } \\
\text { mehrere Jahre }\end{array}$ \\
\hline UV-Strahlung & $\begin{array}{l}\text { Absterben in direktem Licht } \\
\text { nach 20-30 min; in diffusem } \\
\text { Licht bis zu } 11 \text { h Überleben }\end{array}$ & Absterben binnen 2 Tagen \\
\hline Desinfektionsmittel & $\begin{array}{l}\text { Gut empfindlich gegen } \\
\text { übliche Desinfektionsmittel } \\
\text { bekannter Konzentration }\end{array}$ & $\begin{array}{l}\text { Absterben nach > } 60 \text { min in 5- } \\
10 \% \text { Formalin; absoluter } \\
\text { Alkohol ohne Wirkung } \\
\text { Überleben in } 10 \% \text { Jodtinktur } \\
\text { für mehrere Tage }\end{array}$ \\
\hline Fördernde Metabolite & $\begin{array}{l}\text { Kalziumsalze, Glukose, } \\
\text { Ascorbinsäure, Thioglycol- } \\
\text { säure, Cystein, Glutation, } \\
\text { metallische Eisenverbin- } \\
\text { dungen, gesättigte Fettsäuren, } \\
\text { 2-10\% } \mathrm{CO}_{2} \text { essentiell }\end{array}$ & $\begin{array}{l}\text { Methionin, Milchsäure, } \\
\text { Nicotinamid, } \mathrm{Na}^{+} \text {-Ionen }\end{array}$ \\
\hline Ionisierende Strahlung & & $\begin{array}{l}\text { Überleben 1,5 Mrad }\left({ }^{60} \mathrm{Co}-\right. \\
\text { Quelle) }\end{array}$ \\
\hline
\end{tabular}

Tab. 1: Ökologische Parameter der vegetativen Zellen und Sporen von Cl. tetani (Mitscherlich und Marth, 1984; Marek und Mocsy, 1951) 
Die Bildung des Tetanustoxins (syn. Tetanospasmin) von C. tetani ist streng mit dem Wachstum von C. tetani assoziiert. Die Toxinproduktion ist abhängig von verschiedenen toxigenen Faktoren im Kulturmedium. SANADA und NISHIDA (1965) fanden eine indirekte Proportionalität der Fähigkeit zur Glukose- und Maltosefermentation zur Toxigenität von Tetanospasmin. Sie fanden nichttoxische Stämme häufiger von Proben, die zuvor mit hohen Temperaturen inkubiert wurden. Bei Glutamatüberangebot erfolgte durch die Induktion einer verkürzten stationären Phase einen geringere Toxinproduktion. Toxinogene Stämme verloren ihre Fähigkeit zur Toxinproduktion nach Kultivierung in flüssigen Medien. Wenig toxinogene Stämme zeigten eine geringgradige Tendenz zur Sporulation (Bizzini, 1979).

Die Bildung von Tetanospasmin erreicht ihr Maximum und eine folgende Plateauphase nach ca. 45 h Kulturzeit, kurz vor der Autolyse der Zellen (Ozutsumi et al., 1985).

C. tetani kodiert ein archetypisches Phosphocarrierprotein (HPr), das wahrscheinlich eine Rolle im phosphoenolpyruvatabhängigem Phosphotransferasesystem und der Genregulation beim Transport und der Phosphorelierung von C-Substraten spielt (Tangney und Mitchell, 2004).

Bereits FAIRWEATHER und LYNESS (1986) entschlüsselten die Nukleinsäuresequenz von C. tetani. BRÜGGEMANN et al. (2003) identifizierten die Genomsequenz von C. tetani. Das Genom umfasst 2.799.250 bp. Der G+C-Gehalt beläuft sich auf 24,5 \%. Das 74.082 bp große Plasmid kodiert für Tetanospasmin und eine Kollagenase (Brüggemann, 2003; Brüggemann und Gottschalk, 2003).

Sowohl im Chromosom, als auch im 74 kb-Plasmid (pE88) wurden Virulenzfaktoren identifiziert. Tetanolysin, Hämolysin, Collagenase, fibronektinbindende Proteine und Internalin sind homolog zu anderen Clostridien (Perego et al., 2004).

\subsection{Tetanus}

\subsubsection{Pathogenese, Klinik und Therapie}

Das klinische Bild des Tetanus wird durch die Sezernierung von 2 Exotoxinen von C. tetani hervorgerufen. In der Hauptsache vermittelt Tetanospasmin die Neurotoxizität, während 
Tetanolysin zur Komplikation der Erkrankung durch kardiotoxische Wirkungen beiträgt (RKI, 2002).

Nach Eintritt der Sporen in eine Primärläsion mit nachfolgender Senkung des Redoxpotentials kommt es unter anaeroben Bedingungen zur Auskeimung der Sporen und Vermehrung der Tetanusbakterien in der Wunde. Fördernd wirken nekrotisches Gewebe, Kalziumsalze, Glukose, Ascorbinsäure, Thioglykolsäure, Cystein, Glutathion, metallische Eisenverbindungen, gesättigte Fettsäuren und Mischinfektionen mit aeroben und fakultativ anaeroben Begleit- und Wundkeimen, die das Sauerstoffredoxpotential senken (Brandis et al., 1994). TeNT wird als sogenanntes Protoxin in der Bakterienzelle gebildet. Das Protoxin ist eine einzelne Polypeptidkette von ca. 160 kDa, die durch bakterieneigene Proteasen innerhalb der Aminosäurereste 445-461 in das biologisch aktive Toxin gespalten wird. Die Spaltungsregion der C. tetani-Protease ist Teil der Disulfidbrücke. Die Clostridienprotease spaltet selektiv Glu-Asn und Ala-Ser (Gordon und Leppla, 1994). Das aktivierte Tetanustoxin besteht aus einer schweren (H-) und einer leichten (L-) Kette. Die H-Kette vermittelt die Bindung des Toxins an neuronale Oberflächenrezeptoren, während die L-Kette die Neurotransmitterfreisetzung blockiert. Cholesterol ist essentiell für Aufnahme des Toxins (Internalisierung) und Transport in Neuronen (Herreros et al., 2001). WELLHÖNER et al. (1975) konnten durch Autoradiographie mit ${ }^{125} \mathrm{~J}$ nachweisen, dass nach intramuskulärer Injektion von TeNT der größte Teil des Toxins im Epineurium des den Muskel initiierenden Nervens aufsteigt. Der verhältnismäßig kleine Anteil des TeNT, der im intraaxonalen Kompartiment aufsteigt, war für die folgende Akkumulation des TeNT im spinalen Cortex verantwortlich.

In vitro führt die Behandlung von TeNT mit reduzierenden Substanzen, z. B. Dithiothreitol, zur Reduktion der Disulfidbrücke und damit zur Entstehung der H- und L-Kette des Tetanustoxins (Hatheway, 1990).

Die Blockade der Neurotransmitterfreisetzung führt in Folge zum charakteristischen Krankheitsbild des Tetanus. Tetanus ist als Toxoinfektion aufzufassen. Im Gegensatz zur Intoxikation - der Aufnahme toxinhaltigen Materials, implementiert die Toxoinfektion die Toxinbildung erst im Wirtsorganismus. Die Inkubationszeit beträgt 4-14 d, wobei auch Spätformen bekannt sind. Das charakteristische Bild des klinisch manifesten Tetanus ist die Hyperreagibilität in Verbindung mit tonisch-klonischen Krämpfen der ventralen Muskulatur und der Extremitäten. Die Auslösung der Krämpfe erfolgt durch optische, akustische oder Berührungsreize. Das Bewusstsein ist ungetrübt. Der Tod tritt durch Lähmung der 
Schlundmuskulatur, des Zwerchfells und der Glottis ein. Bei leichten lokalisierten Fällen kann Muskelstarre ohne Krämpfe auftreten. Die Letalität schwankt in Abhängigkeit von Impfstatus und Serumprophylaxe zwischen 50-90 \%, wobei die Letalität bei kurzen Inkubationszeiten höher ist. Klinisch manifester Tetanus ist durch sogenannte Kardinalsymptome gekennzeichnet, die bei Menschen und verschiedenen Tierarten unterschiedlich ausgeprägt sein können ( ${ }_{\mathrm{a}}$ Brandis et al., 1994; ${ }_{\mathrm{b}}$ Marek und Mocsy, 1951).

- Mensch $_{\mathbf{a}}$ : Trismus, Tonuserhöhung der Kaumuskulatur, Risus sardonicus, Ophistotonus - Pferd $\mathbf{b}_{\mathbf{b}}$ frühzeitig Trismus, Sägebockstellung, Risus sardonicus, Schweif aufgestellt, nach einer Seite gebogen, Erregbarkeit allgemein stark erhöht

- Rind $\mathbf{b}$ : Abstumpfung, Einsinken der Augen, wenig hochgradige Maulsperre, Erregbarkeit nur mäßig erhöht, frühes Aufblähen

- Schaf, Ziege $\mathbf{b}$ : Ophistotonus; Trismus; starre Haltung des Schwanzes; stelzenartiger Gang; bei Lämmern nicht selten als Stallseuche

- Schwein $\mathbf{b}$ : Trismus, schnell eintretende allgemeine Muskelstarre, in Seitenlage stark nach rückwärts gerichtete Gliedmaßen, heiseres Grunzen

Grundsätzlich unterscheidet man drei Formen von Tetanus. Neben der milder verlaufenden lokalen Form, sind der generalisierte Tetanus und der Tetanus neonatorum durch eine hohe Mortalität gekennzeichnet. Beim Tetanus neonatorum erfolgt der Entritt der Sporen über den Nabelschnurstumpf bei der Geburt oder während der ersten Lebenstage (Guardiola et al., 2000).

Tetanus ist beim Menschen eine polysystemische Erkrankung. Neben dem ZNS können das autonome Nervensystem, das endokrine und kardiovaskuläre System, Lunge, Nieren, Leber und Gastrointestinaltrakt betroffen sein (Kryzhanovsky, 1975, Cook et al., 2001). SOUTTIURAI und FEDINEC (1975) führten TeNT-Intoxikationsexperimente an Ratten durch. Sie konnten verschiedene morphologische Veränderungen der Zellen des renalen proximalen Tubulus beobachten: Schwellung und Risse der Mitochondrien, Ablösen der Mikrovilli, Zellauflösung. Sie schlossen daraus, dass eine akute Nephropathie und die resultierenden Elektrolytimbalancen die neuromuskuläre Manifestation des Tetanus fördern können.

ODUSOTE und FEMI-PEARSE (1975) bestimmten bei Menschen eine erhöhte Aktivität der Kreatinkinase innerhalb der ersten 12 h nach Symptombeginn. Nach VAKIL et al. (1975) 
verhält sich die Kreatinkinaseaktivität dabei direkt proportional zur Schwere der Tetanuserkrankung.

Nach intramuskulärer Applikation von TeNT an Katzen haben GONZALEZ-FORERO et al. (2003) verlängerte synaptische Blockaden sowie selektive Veränderungen der Synapsen und Sensitivitäten der Augenpositionen und Velozität des N. abduzens im Sinne einer partiellen Blockade der neuromuskulären Transmission beobachtet.

Als prädisponierende Faktoren für die Entstehung einer Tetanuserkrankung werden beim Menschen chronische Ulzerationen, Veneninsuffizienz, Sichelzellanämie, Hansensche Krankheit, Mangelernährung, Diabetes mellitus und Traumen (Greco et al., 2001) sowie Vitamin A-Mangel (Molrine et al., 1995) angezeigt. Im Gegensatz dazu konnten EDSALL et al. (1975) keinen Einfluss einer Mangelernährung auf die Stärke der Immunantwort nach Tetanustoxoidierung feststellen.

Therapeutisch steht die Wundversorgung und Wundtoilette im Vordergrund. Gegebenfalls sollte durch chirurgische Maßnahmen nekrotisches Gewebe entfernt werden. Die antimikrobielle Therapie schließt die Gabe von Metronidazol, alternativ Erytromyzin, Tetracyclinen, Chloramphenicol und Clindamyzin ein (Cook et al., 2001). Penicillin G sollte nicht bei generalisiertem Tetanus verabreicht werden, da es eine primäre, vom TeNT unabhängige antagonistische GABA-Aktivität besitzt (Frederick und Abrahamian, 2001).

Die Einleitung einer umfassenden Intensivtherapie zur Erhaltung der vitalen Funktionen, Relaxierung der Muskulatur und Freihalten der Atemwege kann lebensrettend sein. Todesursachen sind vor allem respiratorische Insuffizienz und kardiovaskuläre Komplikationen (RKI, 2002). Die Gabe von Antitoxin (Hyperimmunglobulin) kann im Blutkreislauf zirkulierendes Toxin neutralisieren. Bereits neuronal gebundenes Toxin kann von antitoxischem Serum nicht neutralisiert werden.

MULLINAX et al. (1990) schufen mit der Entwicklung von Immunexpressionsbibliotheken mit Bakteriophagen $\lambda$-Vektoren und E. coli Möglichkeiten zur Entwicklung moderner potentieller therapeutischer Mittel. Klone mit tetanustoxinbindender Domäne wurden mit einer Häufigkeit von 0,2 \% exprimiert. Die Klone bestanden aus H-Kettenfragment, das kovalent an die L-Kette gebunden ist. SHEPPARD et al. (1984) gelang die Herstellung 
monoklonaler Antikörper gegen das Fragment C des TeNT in Myelom- und Milzzellen tetanustoxoidimmunisierter Ratten.

\subsubsection{Epidemiologie}

Besonders empfänglich gegenüber TeNT sind Menschen, Pferde, Rinder, Schafe, Schweine und Affen. Katzen, Hunde, Vögel und alle kaltblütigen Tiere sind resistent (Mitscherlich und Marth, 1984). In der heutigen Zeit ist Tetanus beim Menschen in der Regel eine Erkrankung der tropischen und subtropischen Regionen der Erde. Die globale Inzidenz beläuft sich nach GUARDIOLA et al. (2000) auf 18 Fälle pro 100.000 Einwohner. Die Inzidenzrate ist auch in den Entwicklungsländern niedrig. Die Mortalität der Risikogruppen über 60 Jahre beträgt 50 \% (Cook et al., 2001). Die Inzidenz in Afrika beträgt etwa 10-50 Erkrankungen/100.000 Einwohner. Schätzungen belaufen sich auf über eine Million Todesopfer pro Jahr. Neonataler Tetanus macht ca. $1 / 4$ der gesamten Kindersterblichkeit weltweit aus (RKI, 2002; Madico et al., 1996). In Afrika und Asien treten 5-30 Fälle von neonatalem Tetanus auf 1000 Geburten auf. In Mitteleuropa treten Einzelerkrankungen vorwiegend bei älteren Erwachsenen auf (Mutter et al., 2004).

WILKINS et al. (1988) untersuchten die Vorkommenshäufigkeit von C. tetani in Böden extensiv genutzter Weiden Südafrikas. Um Durban betrug sie 28 \%. Auf über 20 Jahren als Pferdweide genutzten Flächen betrug die Inzidenz 65 \%, obwohl kein Fall von equinem Tetanus nach Beweidung auf diesen Arealen auftrat. Pferde scheiden C. tetani nach oraler Aufnahme nur für drei bis vier Tage aus. 5-9 \% der untersuchten Pferde schieden C. tetani über vier Monate aus. Die Ausscheidungsrate bei Stallpferden war gering (2 von 27).

Die Infektion erfolgt ausschließlich über kontaminierte Böden, Staub und Schmutz. Eintrittspforten sind tiefe Verletzungen oder Schürfungen nach Traumen sowie der Nabelschnurstumpf bei Neugeborenen. 


\subsection{Toxine}

\subsubsection{Tetanustoxin (syn. Tetanospasmin)}

Tetanospasmin (TeNT) ist eines der wirkungsvollsten Bakteriengifte. Es kann mittels Ammoniumsulfatgradienten aus Kulturüberstand von C. tetani isoliert werden (Holmes und Ryan, 1971). Es ist in großen Bereichen homolog zum Botulinum-Neurotoxin (Schiavo et al., 2000). Die $\mathrm{LD}_{50}$ wird für Menschen mit < 2,5 ng/kg Körpermasse angegeben (WHO, 1993). Besonders empfindlich gegenüber TeNT sind Mensch und Pferde. Reines Protein, gelöst in Phosphatpuffer, hat eine optische Dichte bei 280/260 nm von 2,1 (Murphy und Miller, 1967). Die Bildung des Toxins im Bakterium wird über ein großes Plasmid reguliert. Atoxische Stämme sind durch Verlust des Plasmids gekennzeichnet. Das biologisch aktive Tetanustoxin besteht aus zwei, über Disulfidbrücken verbundenen Polypeptidketten (Schiavo et al., 1990).

Durch Behandlung des intakten Tetanustoxins mit Dithiothreitol und 2-Mercaptoethanol können die Disulfidbrücken zerstört werden. Als Resultat liegt das Tetanustoxin in zwei distinkten Fragmenten vor: H- und L- Kette (100 kDa bzw. 50 kDa). VOLK et al. (1984) identifizierten mit Hilfe monoklonaler Antikörper mindestens neun antigene Determinanten, sowohl auf der aminoterminalen, als auch auf der carboxyterminalen Hälfte der H-Kette. Die Aminosäuresequenz der L-Kette besitzt gemeinsame antigene Determinanten zu Botulinumtoxinen A, B, E und $\mathrm{C}_{1}$ (Tsuzuki et al., 1988). LIN et al. (1985) identifizierten mittels ELISA und Inhibitions-Neutralisationstest immunogene Determinanten auf der LKette des TeNT.

Die L-Kette ist eine Metallo-Zink-Endopeptidase (Cornille et al., 1997; Häse und Finkelstein 1993; Schiavo et al., 1992). BHATTACHARYYA und SUGIYAMA (1990) inaktivierten Tetanustoxin und Botulinumtoxin in vitro durch Zugabe von Chelatoren. Sie schlossen daraus, dass Metallionen notwendig sind, damit TeNT seine biologische Wirkung entfalten kann. Tetanustoxin bindet via H-Kette an die Ganglioside der G1b-Serie der peripheren Nervenendigungen (Angström et al., 1994). An Mäuseneuronen, die mit einem selektiven Gangliosidsyntheseinhibitor inkubiert wurden, konnten WILLIAMSON et al. (1999) zeigen, dass Ganglioside für die Entfaltung der Toxinwirkung notwendig sind. SCHIAVO et al. (1991) identifizierten ein 15-20 kDa großes Rezeptorprotein für TeNT auf neuronalen Zellen (zit. von Herreros et al., 2000). Nach Toxinbindung wird TeNT durch rezeptorvermittelte 
Endozytose internalisiert und wandert durch axoplasmatischen Transport zum ventralen Horn des Rückenmarks. Die Wanderungsgeschwindigkeit entlang der peripheren Nerven bis zum ZNS beträgt ca. 5 mm/h (RKI, 2002). Nach Freisetzen in den Interneuralraum wird TeNT durch dem Soma der Motoneuronen angrenzende, inhibitorische Interneuronen aufgenommen. In Vesikel internalisiertes TeNT vermittelt eine $\mathrm{pH}$-abhängige Konformationsänderung, welche zur Translokation des TeNT durch die endosomalen Membranen ins Zytosol führt. Dort wird die L-Kette durch Enzyme (z. B. Thioreduxinreduktase) von der H-Kette abgespalten. In deren Folge spaltet die L-Kette (=aktivierte Protease) Synaptobrevin 2 (Pitzurra et al., 1993). Synaptobrevin 2 ist ein $12 \mathrm{kDa}$ großes, präsynaptisches vesikelmembranassoziiertes Protein, das in Anwesenheit von Kalziumionen einen stabilen Komplex mit zwei Plasmamembranproteinen - Syntaxin und SNAP 25 bildet (Antonin et al., 2000; Schiavo et al., 2000). Die Komplexbildung initiiert die Fusion der neurotransmitterhaltigen Vesikel mit der Plasmamembran (Herreros et al., 2001). Die Spaltung von Syntaxin 2 durch TeNT blockiert die kalziumabhängige Exocytose der inhibitorischen Transmitter Glyzin, $\gamma$-Aminobuttersäure, Glutamat, Aspartat und MetEnkephalin (McMahon et al., 1992; Verderio et al., 1999; Quetglas et al., 2002; Galli et al., 1998; Togo et al., 2003). Exitatorische Impulse können ungefiltert weitergeleitet werden (Bartels und Bigalke, 1992). Zusätzlich zur Aktivität des TeNT im motorischen System wird TeNT auch durch die Nervenendigungen der sensorischen und vegetativen Nerven aufgenommen (Anonymb, 2005).

Eine milde enzymatische Spaltung des TeNT mit Papain initiiert die Bildung zweier Polypeptidfragmente. Das größere Fragment $\left(\mathrm{M}_{\mathrm{r}} 100.000\right)$ besteht aus dem $\mathrm{NH}_{2}$-terminalen Teil der L-Kette. Es beinhaltet die pH-abhängige Translokationsdomäne. Die kleinere Polypeptidkette $\left(\mathrm{M}_{\mathrm{r}}\right.$ 50.000), bestehend aus dem karboxyterminalen Teil der H-Kette, wird als C-Fragment bezeichnet (Matsuda et al., 1989). Sie vermittelt die Gangliosidbindungsaktivität und Internalisierungseigenschaften, die mit dem intakten TeNT assoziiert sind (Herreros et al., 2000). Das C-Fragment selbst ist nichttoxisch. Es wird wie das intakte Toxin retrograd transportiert (Bizzini und Fedinec, 1989). Das Tetanusfragment C ist in die spezifische Aktivierung der Proteinkinase C-Isoformen und des intrazellulären Signaltransduktionsweges involviert (Gil et al., 2001).

Die Toxinbildung wird durch ein unmittelbar stromabwärts vom Tetanusgen gelegenes TetRGen positiv reguliert. Das TetR-Gen, ein 21562 Da großes Protein, weist 50-56 \% Homologie 
zum BotR-Gen auf. Die Regulierung der Toxinbildung in C. tetani und C. botulinum scheint ein konservierter Mechanismus zu sein (Marvaud et al., 1998).

\subsubsection{Tetanolysin}

Tetanolysin ist ein sauerstoffsensitives Hämolysin, das funktionell und serologisch mit Streptolysin O verwandt ist. Seine Molekülmasse beträgt ca. 48 kDa-51 kDa. Zugabe von Tetanolysin zu Erythrozyten, polymorphkernigen nukleären Zellen, Makrophagen, Fibroblasten, verschiedenen Tumorzellen und Thrombozyten führt durch Veränderungen des isoelektrischen Punktes zur Zelllyse. COX et al. (1973) konnten die Lyse von humanen und Kaninchenthrombozyten durch Zugabe von Antitoxin verhindern. Bei Kontakt der Thrombozyten mit Tetanolysin schwollen die Zellen an. Auf der Zelloberfläche bildeten sich Pseudopodien und Bläschen. Die Thrombozyten schrumpften. Es kam zur Freisetzung von Serotonin, hydrolytischen Enzymen und Proteinen aus dem Zellinneren. Die lytische Aktivität war reversibel durch Sauerstoffzutritt (Belüftung, $\mathrm{H}_{2} \mathrm{O}_{2}$ ) oder durch Gabe von Thiolen, wie beispielsweise Zystein, reduziertem Glutathion und Thioglycolat. Das aktive Toxin besitzt eine Affinität zu Cholesterol und verwandten Sterolen und kann durch diese Reagenzien in vitro gehemmt werden. Beim Kaninchen löst intravenös appliziertes Tetanolysin Lungenödem mit Todesfolge aus, bei Kaninchen und Affen eine intravaskuläre Hämolyse. Bei Affen treten zusätzlich Veränderungen im Elektrokardiogramm in Folge ansteigendem Herzschlag bedingt durch toxinassoziierte kardiotoxische Effekte auf (Hatheway, 1990).

\subsection{Immunologie}

Die Entwicklung einer tetanustoxoid-vermittelten Immunität ist in erster Linie humoraler Natur. Neuere Untersuchungen belegen eine Beteiligung der T-Zell-vermittelten Immunreaktion an der Entwicklung einer Anti-TeNT-Immunität (Woo et al., 1999). Die humorale Immunreaktion ist durch die Synthese und Sekretion von Antikörpern bzw. Immunglobulinen gekennzeichnet. KROON et al. (1999) beschrieben eine T-Zell-induzierte Immunantwort beim Menschen. Patienten mit HIV-Infektion zeigen nur eine schwache Immunantwort auf Tetanusvakzinierung. Diese Beobachtungen könnten auf Defekte in der TZell-vermittelten Immunantwort zurückzuführen sein. Obwohl serumspezifische Antikörper 
Marker der humoralen Immunantwort sind, können auch Defekte der zellulären Immunantwort durch niedrige Antikörper-Titer angezeigt werden (Schauer et al., 2003). An mononukleären Zellen von Kindern wiesen ROWE et al. (2000) in vitro eine TH2-Zellassoziierte frühe Immunantwort nach. Die verzögerte Reifung der TH1-Komponente bei Kindern könnte durch Entwicklungsprozesse des Immunsystems im frühen Kindesalter bedingt sein. Während der Periode zwischen der primären Impfung und der ersten Boosterung (erste 18 Lebensmonate) war der Grad der tetanustoxoidspezifischen Immunantwort relativ niedrig. Protektive Immunantworten entwickelten sich erst bei der Entwicklung der zellulären (TH1-Zell-vermittelten) Reaktion. Die Zeit zwischen primärer Immunisierung und erster Boosterung bezeichneten sie darum als „window of increased risk“ (Rowe et al., 2000). Eine überstandene Tetanuserkrankung vermittelt keinen Schutz gegen weitere Infektionen. Alle Patienten mit klinischem Tetanus sollten bereits während der Erkrankung bzw. spätestens in Rekonvaleszenz mit Toxoidimpfstoff immunisiert werden (WHO, 1993).

Der Grad der Immunantwort, basierend auf dem immunologischen Gedächtnis, variiert stark in Abhängigkeit vom Alter. Bei älteren Menschen steigt die Möglichkeit einer Tetanusinfektion (Schatz et al., 1998).

Die Entwicklung einer tetanustoxinvermittelten Immunantwort ist von weiteren Faktoren abhängig. MOLRINE et al. (1995) beobachteten eine Verschlechterung der Immunantwort auf Tetanustoxoid bei SCID-Mäusen unter Vitamin A-Mangel. Supplementierung von Vitamin A führte nachfolgend zu einer normalisierten Immunreaktion mit dem Aufbau protektiver Level. GUARDIOLA et al. (2000) beobachteten bei vakzinierten Schwangeren eine verringerte Immunantwort nach Vitamin A-Mangel und Infektionen mit Plasmodium falciparum. Bei Menschen wiesen COOPER et al. (1999) bei Wurminfektionen mit Onchocerca volvulus und intestinalen Helminthen eine veränderte Immunantwort hinsichtlich differenzierter IgG-Subtypenverteilungen nach. Trotz schwerer Infektionen führte die veränderte Immunreaktion zur Ausbildung protektiver Titer, der mit 0,15 IU/ml angegeben wurde.

\subsubsection{Natürlich erworbene Immunität}

Die Fähigkeit zur Entwicklung einer natürlich erworbenen Anti-Tetanus-Immunität bei Menschen oder Tieren wird heute als nicht gegeben angesehen (WHO, 1993). 
MATZKIN und REGEV (1985) fanden eine altersabhängige, aber geschlechtsunabhängige Entwicklung einer natürlich erworbenen Immunität bei einer isolierten Gemeinschaft jüdischer Emigranten in Äthiopien. Bei einem Cut off von 0,01 IU/ml bestimmten sie mittels ELISA 30 \% der Probanden mit protektivem Level gegen Tetanus. VERONESI et al. (1975) propagieren eine natürliche Immunität gegen Tetanus bei Mensch und Tier. An Versuchen mit Menschen, Hunden, Pferden, Meerschweinchen und Schweinen fanden sie protektive Titer. Ungeimpfte drei bis fünf jährige Pferde hatten zu 97 \% schützende Titer >0,01 IU/ml. Im Gegensatz zu MATZKIN und REGEV (1985) titrierten sie die Seren im MeerschweinchenNeutralisationstest.

Die Kolonisation des Darmes ist Basis der Theorie der natürlichen Immunität. Es ist allgmein akzeptiert, dass Tetanustoxin vom Gastrointestinaltrakt aufgenommen werden kann. Transientes Tetanustoxin könnte die Produktion von Antikörpern induzieren. Die Rate der Adsorbtion ist abhängig von der Konzentration des Toxins, der Spezies, von Alter und vom Zustand der Darmschleimhaut. Es ist wenig über Faktoren bekannt, die die Produktion von TeNT im Darm beeinflussen können. Obwohl Pferde sehr empfindlich gegenüber TeNT sind, ist C. tetani häufig in ihrem Darmtrakt kolonialisiert (WHO, 1993). UMESAKI et al. (1999) wiesen gnotobiotische Effekte im Dickdarm durch die Produktion großer Mengen kurzkettiger Fettsäuren und Gallensäuren durch Clostridien nach.

\subsubsection{Künstlich erworbene Immunität}

Künstlich erworbene Immunität gegen Tetanus wird über die aktive oder passive Immunisierung vermittelt. Die aktive Immunisierung erfolgt mit formalininaktiviertem Toxoidimpfstoff. Im Gegensatz zum Toxin ist das Toxoid immunogen, aber nicht toxisch. Diese Form der Immunisierung führt zur Ausbildung eines langanhaltenden immunologischen Gedächtnisses in Form der Sezernierung von Immunglobulinen in verschiedenen Körperflüssigkeiten. Passive Immunität wird durch die Gabe von Anti-Tetanus-IgG vermittelt, das zu einem sofortigen aber kurzzeitigen Schutz gegen TeNT führt. Es implementiert keine Bildung eigener Immunglobuline. Eine passive Immunisierung erfolgt in der Regel bei entsprechender Exposition von Menschen oder Tieren mit unklarem bzw. unvollständigem Impfregime. 
Eine Sonderform der passiven Immunität ist die Transfektion des menschlichen Fetus mit maternalen IgG sowie die Aufnahme von maternalem IgG durch das Kolostrum. Während der Gravidität des Menschen kann ausschließlich IgG die Diaplazentarschranke passieren, in den fetalen Kreislauf übertreten und dort persistieren. IgG wird beim Menschen vom vierten Schwangerschaftsmonat an bis zur Geburt auf den Fetus übertragen. Das Verhältnis der Antikörper im Nabelschnurserum zum Mutterserum ist abhängig von der Art der Impfintervalle. Lange Intervalle zwischen den Impfungen führen zu einer hohen und dauerhaften Immunantwort (WHO, 1993). Nach GUARDIOLA et al. (2000) ist der IgGGehalt der Mutter gleich hoch wie der des Fetus’. Danach werden schützende Antitoxingehalte bei neugeborenen Säuglingen mit 0,01-0,015 IU/ml angegeben. LIU et al. (1982) bestimmten den Gehalt der maternalen Antikörper im Serum neugeborener Fohlen bei einem Grenzwert von 0,01 IU/ml. Ein Monat p. p. wiesen 16,6 \% der Fohlen einen Titer $<0,01 \mathrm{IU} / \mathrm{ml}$, zwei Monate p. p. 60,7 \% < 0,01 IU/ml, drei Monate p. p. 75,5 \% < 0,01 $\mathrm{IU} / \mathrm{ml}$ und vier Monate p. p. 81,1 \% < 0,01 IU/ml auf. Die Gabe von Antitoxin (passive Immunisierung) bei der Geburt der Vergleichsgruppe verursachte einen Anstieg der Antikörper für mindestens drei Monate. WILSON et al. (2001) impften Saugfohlen mit Tetanustoxoid. Sie stellten fest, dass mit dem Kolostrum aufgenommenes Anti-Tetanus-IgG die Immunantwort auf Tetanustoxoidimpfstoff inhibiert. Im Gegensatz dazu zeigten Jährlinge eine starke IgG-vermittelte Immunantwort auf eine einmalige Gabe von Toxoid. Die Titer stiegen im Anschluss an eine Boosterung drei Wochen nach Erstimmunisierung weiter an. Sie schlossen aus den Ergebnissen, dass maternale Antikörper einen signifikant inhibitorischen Effekt auf die Ausbildung der Immunantwort nach Gabe von Tetanustoxoid an Saugfohlen haben. Die Grundimmunisierung von Fohlen immunisierter Mütter sollte daher nicht vor einem Alter von sechs Monaten erfolgen. Bei in vitro-Versuchen mit tetanustoxoidstimulierten mononukleären Zellen nicht immunisierter Pferde konnten IgGKonzentrationen ab dem fünften Tag gemessen werden. Die maximale Konzentration nach Toxoidstimulation wurde am 10. Tag bestimmt (O’Brien et al., 1992).

\subsubsection{Immunglobuline}

Antikörper bzw. Immunglobuline sind Glykoproteine, die bei elektrophoretischer Auftrennung in der sogenannten $\gamma$-Globulinfraktion wandern. Alle Immunglobuline bestehen aus mindestens vier Polypeptidketten mit jeweils zwei identischen schweren (H-) Ketten und 
leichten (L-) Ketten. Ihre Grundstruktur ist das Tetramer. Die Summenformel der Immunglobuline ist $\left(\mathrm{H}_{2} \mathrm{~L}_{2}\right) \mathrm{n}$, wobei n die Zahl der Grundeinheiten der verschiedenen Immunglobuline angibt. Die H- und L-Ketten der Immunglobuline werden durch Disulfidbrücken verbunden. H-Ketten bestehen aus ca. 450-600 Aminosäuren, L-Ketten aus ca. 220 Aminosäuren. Die klassenspezifischen Eigenschaften der verschiedenen Immunglobuline werden durch die Diversität der H-Ketten definiert. Die Antigenbindungsstelle ist die Kombination der variablen $\mathrm{H}$ - und L-Kettenregionen des Moleküls (Wecker, 1990).

Tab. 2 zeigt die alte, sowie eine vorgeschlagene Nomenklatur der equinen Immunglobulinklassen (Wege, 2004). Innerhalb der vorliegenden Arbeit wurde auf die sprachgebräuchliche ältere Klassifizierung zurückgegriffen.

\begin{tabular}{c|c} 
Klassische Nomenklatur & $\begin{array}{c}\text { Vorgeschlagene } \\
\text { Nomenklatur }\end{array}$ \\
\hline IgM & $\operatorname{IgM}$ \\
IgGa & $\operatorname{IgG}_{1}$ \\
& $\operatorname{IgG}_{2}$ \\
IgG(T) & $\operatorname{IgG}_{3}$ \\
IgGb & $\operatorname{IgG}_{4}$ \\
& $\operatorname{IgG}_{5}$ \\
& $\operatorname{IgG}_{6}$ \\
IgE & $\operatorname{IgE}^{\text {IgA }}$ \\
\end{tabular}

Tab. 2: Nomenklaturen der Immunglobulinklassen des Pferdes (mod. nach Wege, 2004)

\subsubsection{IgG}

IgG ist das dominierende Immunglobulin im Blut und Kolostrum. Es wird von Plasmazellen der Milz, der Lymphknoten und des Knochenmarkes gebildet. IgG besteht aus zwei identischen L-Ketten vom $\kappa$ - oder $\lambda$-Typ und $2 \gamma$-H-Ketten. Die Molekülmasse beträgt 180 
kDa. IgG kann von den Blutgefäßen aus in entzündetes Gewebe einwandern. Die Bindung von Antigenen durch IgG führt zu einer Agglutinierung und Opsonierung. Unter bestimmten Voraussetzungen ist IgG in der Lage, das Komplementsystem zu aktivieren (Tizard, 2004).

IgG $_{1}$ ist der dominierende IgG-Subtyp nach Vakzinierung mit Tetanustoxoid (Kroon et al., 1999). BOUVET et al. (1994) wiesen Anti-Tetanus-IgG in humanen Vaginalsekret nach parenteraler Immunisierung mit Tetanustoxoid nach. Der Antikörpergehalt im Genitaltrakt korrelierte dabei mit den Serumwerten und Gesamt-IgG-Gehalt.

\subsubsection{IgM}

IgM wird ebenfalls durch Plasmazellen der Milz, Lymphknoten und des Knochenmarkes gebildet. Es liegt nach IgG in der zweithöchsten Konzentration im Serum der meisten Säugetiere vor. In anderen Körperflüssigkeiten ist IgM auf Grund seiner Größe nur in geringem Maße zu finden. Die biologisch aktive Form des IgM ist ein Polymer aus gewöhnlich fünf, über Disulfidbrücken verbundenen Einheiten. Seine Molekülmasse beträgt 900 kDa. IgM ist das vorrangig produzierte Immunglobulin während der initialen primären Immunantwort. IgM vermag effizient Komplement zu aktivieren und zu opsonieren. Es ist in Virusneutralisation und Agglutination involviert (Roitt et al., 2001).

\subsubsection{IgA}

IgA ist das Hauptimmunglobulin der Tränenflüssigkeit und der Milch. Es wird von Plasmazellen des Verdauungsapparates, des Respirationstraktes, des Harnapparates, der Haut und der Milchdrüsen produziert. Die Konzentration von IgA liegt unter dem IgM-Titer. IgAMonomere haben eine Größe von 150 kDa. Zwei L-Ketten sind mit zwei $\alpha$-H-Kette kombiniert. Der Hauptteil des IgA wird in den Darmwänden gebildet und in das Darmlumen entlassen. Während des Transportes durch die intestinalen Epithelzellen wird IgA an einen 71 kDa großen Rezeptor gebunden. Dieser sekretorische Rezeptor bindet an IgA-Dimere. Es entsteht sekretorisches IgA (SIgA). SIgA ist das vorherrschende Immunglobulin der Körperflüssigkeiten bei Nichtwiederkäuern. IgA kann Komplement nicht aktivieren oder 
opsonieren. Die Hauptaufgabe des IgA ist der Schutz der Haut- und Schleimhautoberflächen vor mikrobieller Invasion (Marcotte und Lavoie, 1998).

Im Gegensatz zu reifer Milch enthält Kolostralmilch nur wenig IgA. Das Verhältnis von IgA zu IgG im Kolostrum 1:34 (McGuire und Crawford, 1972).

\subsubsection{IgE}

IgE wird wie IgA von Plasmazellen produziert, die sich unter der Hautoberfläche befinden. Die Molekülmasse beträgt 190 kDa. Es liegt in sehr niedrigen Serumkonzentrationen vor. Nach Bindung an Mastzellen und basophile Granulozyten vermittelt IgE die Freisetzung ihrer inflammatorischen Substanzen. IgE ist bei Hypersensitivitätsreaktionen vom Typ I involviert. Sein Serumspiegel steigt bei Wurminfektionen an (Tizard, 2004).

\subsection{Vakzinierung}

\subsubsection{Aktive Immunisierung und Impfstoffentwicklung}

Die aktive Immunisierung zur Entwicklung eines individuellen immunologischen Gedächtnisses erfolgt mit Toxoidimpfstoff. Tetanustoxoid wird durch Formaldehydbehandlung des intakten Toxins gewonnen. Die Adsorption von Tetanustoxoid an Aluminiumsalze steigert seine Antigenität. Das Toxoid ist immunogen, aber nicht toxisch. Die Stabilisierung von humanen Tetanus- und Diphterie-Impfstoffen erfolgt durch chemische Derivatisierung (Schwendeman et al., 1995). Der internationale Tetanustoxoidstandard beträgt 469 IE adsorbiertes Toxoid ( $\approx 35$ Lf gereinigtes Toxoid) + 1 mg Aluminium (als Aluminiumphosphat) + 10 mg Trehalose (NIBSC, 2004).

Die aktive Immunisierung mit Tetanustoxoid kann als monovalente, divalente oder polyvalente Impfung in Form eines Kombinationsimpfstoffes verabreicht werden. Das Impfschema für Menschen und Pferde ist in Tab. 3 dargestellt. Im Gegensatz zur Humanmedizin wird die Wiederholungsimpfung bei Pferden bereits nach zwei Jahren durchgeführt. 


\begin{tabular}{|l|l|l|}
\hline & Mensch $_{\mathrm{a}}$ & Pferd $_{\mathrm{b}}$ \\
\hline Grundimmunisierung I & ab 3. Lebensmonat & $\begin{array}{l}\text { Nach dem Absetzen; 5.-6. } \\
\text { Lebensmonat }\end{array}$ \\
Brundimmunisierung II & $\begin{array}{l}\text { sechs Wochen nach 1. } \\
\text { Grundimmunisierung }\end{array}$ & $\begin{array}{l}\text { vier Wochen nach 1. } \\
\text { Grundimmunisierung }\end{array}$ \\
Auffrischung & Nach 8-12 Monaten & Nach 12 Monaten \\
Nach 10 Jahren & Nach zwei Jahren
\end{tabular}

a Milatovic und Braveny (1997)

b Tizard (2004), Ullrich et al. (1985)

Tab. 3: Impfschema für Menschen und Pferde

MUMFORD et al. (1994) beschrieben spezifische Tetanus-Antikörperspiegel von $\geq 0,01$

IU/ml für mindestens 20 Monate nach Immunisierung bei New Forest Ponies (tiefe intramuskuläre Injektion von einer Dosis Influenzavakzine und einer zweiten Dosis TetanusInfluenzavakzine im Abstand von sechs Wochen, sowie einer Boosterung mit Influenzavakzine). Die intramuskuläre Injektion von einmalig 8-16 Lf Tetanustoxoid konnte erwachsene Pferde für mindestens 128 Wochen schützen. Eine Boosterung mit acht Lf bildete spezifische Antikörpergehalte für weiter 3,5 Jahre. Die intramuskuläre Injektion von acht Lf bei 10-18 Wochen alten Fohlen führte zu keiner Immunantwort. Tetanusspezifische Titer erschienen erst nach einer Boosterung mit weiteren acht Lf nach 12 Wochen im Anschluss an die Grundimmunisierung (Jansen und Knoetze, 1979). HELDENS et al. (2001) immunisierten acht Monate alte seronegative Fohlen mit einem trivalenten Impfstoff (Influenza, Tetanus, Herpes) und verfolgten die anti-Tetanus-Titer mittels ToBi-ELISA bis ein Jahr nach Erstimpfung. Die Titer erreichten nach der dritten Impfung ihr Maximum. Protektive Titer waren für mindestens ein Jahr gegeben.

Tetanustoxoid wird als allgemein potenter und sicherer Impfstoff angesehen. Vor allem bei hyperimmunisierten Personen kann es in seltenen Fällen zum Auftreten anaphylaktischer Reaktionen kommen. Diese äußern sich als lokale Schwellung und Schmerzen. Bei 0,4 pro 1 Millionen Tetanusimpfungen kann es zu einer Polyneuropathie kommen. Die Komplexbildung der Antikörper mit dem Toxoid kann zu einer Aktivierung des Komplementsystemes und der Leukozyten führen (WHO, 1993). 
Grundlage für die Impfstoffherstellung ist die großtechnische Produktion von Tetanustoxin durch C. tetani. In Folge der niedrigen letalen Dosis birgt der Umgang mit Clostridienneurotoxinen allgemeine Gefahren für nichtimmunisierte Menschen und Tiere. Aus diesem Grund wurden in den letzten Jahren verstärkt Anstrengungen unternommen, die Toxinbasis durch rekombinante Informationsträger bei vergleichbarer Immunogenität zu ersetzen. Modernes Vakzinedesign schafft Möglichkeiten zur Entwicklung globaler sicherer Impfstoffe zur Kontrolle bakterieller Infektionskrankheiten (Curtis, 2002).

FAIRWEATHER et al. (1986) und MAKOFF et al. (1989) schufen mit der Klonierung des nichttoxischen aber immunogenen Tetanustoxinfragment-C in E. coli die Grundlage für moderene Tetanusvakzine. Ein rekombinanter Tetanus-Pertussis-Impfstoff konnte in E. coli hergestellt werden (Boucher et al., 1994). ROMANOS et al. (1991) klonierten TetC in $S$. cerivisiae, CHARLES et al. (1991) in Insektenzellen. TREGONING et al. (2003) immunisierten erfolgreich Mäuse oral und intranasal mit in Tabakchloroplasten expremiertem TetC. Die Tiere zeigten eine systemische anti-TetC-Immunantwort am 27. Tag nach Erstimmunisierung. SHI et al. (2001) immunisierten Mäuse nasal und epikutan mit adenovirusvektorkodiertem TetC. MESNAGE et al. (1999) klonierten erfolgreich Fragment C in B. anthracis. Nukleinsäurevakzinierung von Mäusen mit synthetischer, Fragment Ckodierender DNA schützte die Tiere gegen einen letalen Ausgang des Tetanus (Anderson et al., 1996). DUC et al. (2003) beschrieben TetC beladene Bakteriensporen aus B. subtillis als Vakzinevehikel. 33 Tage nach oraler und intranasaler Immunisierung zeigten Mäuse signifikante Titer. Die Titer gegen Sporenmantelproteine blieben niedrig. SINGH et al. (1997) verkapselten Tetanustoxoid in Mikropartikel aus nichtimmunogenem PolylactidKopolymeren mittels Solvent-Evaporation. Einzeldosenapplikationen des Impfstoffes an Ratten zeigten die gleiche Antigenität des Mikropartikelimpfstoffes im Vergleich zu drei Dosen aluminiumsubstituiertem Toxoidimpfstoff. Die Kombination beider Varianten erzielte die beste Immunantwort.

Eine Sonderform der Vakzinierung ist die intradermale Impfung. Sie wurde bei Menschen und Tieren angewendet und ergab insbesondere bei Boosterungen gute Ergebnisse (Bizzini et al., 1978). Allerdings berichten WHITFORD (1976) und POST (1978) über Nebenreaktionen bei der Anwendung an Pferden. 


\subsubsection{Passive Immunisierung}

Die passive Immunisierung mit sogenanntem Hyperimmunglobulin wird bei Patienten mit unklarem Impfstatus als Postexpositionsprophylaxe bei Verletzungen oder vor Operationen eingesetzt. Hyperimmunglobulin für die Human- und Veterinärmedizin besteht in der Regel aus equinem IgG, das durch wiederholte Immunisierung von Pferden mit Tetanustoxoid gewonnen wurde (WHO, 1993). FORRAT et al. (1998) entwickelten ein Präparat aus HumanIgG zur Erhöhung der Verträglichkeit und Senkung lokaler Reaktionen nach Applikation an Menschen.

Der international gültige Tetanustoxin-Immunglobulin-Standard wird durch das State Serum Institute in Kopenhagen formuliert (Tizard, 2004):

$$
\begin{array}{ll}
1 \mathrm{IE} \text { (syn. IU) } & =0,03384 \mathrm{mg} \text { Tetanus-IgG } \\
1 \text { US-Standard } & =2 \mathrm{x} \mathrm{IE}=0,0768 \mathrm{mg} \text { Tetanus-IgG. }
\end{array}
$$

Eine andere gebräuchliche Einheit zur Definition von tetanusspezifischem Immunglobulin ist die Ausflockungseinheit (Lf) (Seifert und Böhnel, 1995).

$1 \mathrm{Lf} \quad=$ die Menge an Toxin oder Toxoid, die die schnellste Ausflockung mit 1,1 IE Antitoxin (IgG) zeigt

\subsection{Nachweismethoden}

\subsubsection{Direkter Erregernachweis}

Der direkte mikrobiologische Erregernachweis ist für die Diagnostik des Tetanus’ von untergeordneter Bedeutung. In der Regel sind die Ausprägung der spezifisch klinischen Symptome in Verbindung mit der Kenntnis eines unvollständigen Impfregimes ausreichend um die Diagnose Tetanus sicherzustellen.

Bei frischen Verletzungen bzw. Nabelschnurstümpfen kann Wundmaterial entnommen werden. Die Anzucht gelingt nur in anaeroben Milieu auf supplementierten Nährmedien. $C$. tetani erscheint bereits nach 24 h Inkubationszeit. Mit einer Spezialfärbung kann die typische 
trommelschlägerartige Form der sporentragenden Zellen sichtbar gemacht werden. Grundsätzlich sind Clostridien grampositive Mikroorganismen. Das Gramverhalten von C. tetani ist dabei stark von seiner Wachstumsphase abhängig. Reinkulturen fraglicher Kolonietypen können mittels kommerziellen Testkits identifiziert werden. Grundlage dieser Tests bildet die Fermentation vielfältiger Substrate, in der Regel Kohlenhydrate, niedere Alkohole und Aminosäuren. Die biochemische Leistung wird mittels eines implementierten Indikators visualisiert, der in Folge einer Änderung des pH-Wertes auf Grund metabolisierter Fermentationsprodukte, einen Farbumschlag herbeiführt. Das metabolisierte Substratspektrum wird in ein numerisches Profil umgesetzt. Das untersuchte Bakterium wird mittels geräteintegrierter Software und Datenbanken identifiziert. LOCH (2000) verglich $C$. botulinum-Stämme mittels „Bunter Reihen“, PCR und Gaschromatographie. Kommerzielle Kits auf Basis der „Bunten Reihe“ ergaben oft falsche Identifizierungen. Die gaschromatographische Bestimmung des Fettsäurespektrums ist die sensitivste, aber eine aufwändige Methode. Sie kann auf Grund der benötigten Hardware nur in Speziallaboratorien durchgeführt werden und ist nicht zur Routinediagnostik geeignet.

\subsubsection{In vivo-Neutralisationstest}

Die Durchführung des Neutralisationstestes ist die offiziell deklarierte Methode zum Nachweis von Tetanustoxin, sowie zur Impfchargentestung von Tetanustoxoidimpfstoffen und Tetanusimmunsera (Eur. Pharm., 2002). Die Tests werden mit Mäusen, bzw. modifiziert mit Meerschweinchen, durchgeführt und sind daher mit allen, bei Versuchen am lebenden Tier assoziierten Restriktionen verbunden.

\subsubsection{Toxinbestimmung aus Untersuchungsmaterial}

Untersuchungsmaterial eines an Tetanus erkrankten oder gestorbenen Menschen oder Tieres wird Mäusen in Nähe der Schwanzwurzel in eine Hauttasche implantiert. Serum oder Kulturflüssigkeit werden intraperitoneal injiziert. Die Tiere gehen bei Anwesenheit des Tetanustoxins nach ein bis drei Tagen unter den typischen Erscheinungen der „Robbenstellung“ zu Grunde. Ein immunisiertes Vergleichstier soll keine Symptome entwickeln (Brandis et al., 1994). 


\subsubsection{Challengetest zur Impstoffkontrolle}

Die Bestimmung der immunogenen Potenz kommerzieller Impfstoffe wird im ChallengeNeutralisationstest überprüft: Mäuse oder Meerschweinchen werden mit jeweils drei Verdünnungen des Testimpfstoffs und Referenzimpfstoffs vakziniert. Einschließlich einer unbehandelten Kontrollgruppe werden für jeden Batch-Test normalerweise zwischen 66 und 108 Tiere benötigt. Gleichzeitig mit der Vakzinierung, sowie nach vier Wochen, wird den Tieren je eine letale oder paralytische Dosis TeNT subkutan injiziert. In Abhängigkeit der immunogenen Potenz des Testimpfstoffes überleben die Versuchstiere, zeigen typische Krankheitssymptome oder verenden (Eur. Pharm., 2002).

Der Neutralisationstest ist sehr sensitiv, teuer, zeit- und personalintensiv. Die Nachweisgrenze ist 0,001 IU/ml Serum. Der Vorteil des Neutralisationstestes ist die korrekte Bestimmung insbesondere niedrigtitriger Seren (WHO, 1993).

\subsubsection{Passive Hämagglutination}

Bei der passiven Hämagglutination agglutinieren tetanustoxoidsensitivierte Schaferythrozyten spezifisch bei Anwesenheit von tetanustoxinspezifischen Antikörpern. Die Vorteile der passiven Hämagglutination sind der geringe Zeitaufwand, die hohe Sensitivität und die geringen Testkosten (Galazka, 1975). Ergebnisse können innerhalb einer Stunde vorliegen. Die Ergebnisse des passiven Hämagglutinationstestes korrelieren gut mit dem Neutralisationstest. Unterschiede treten vor allem in der Sensitivität bei Seren mit niedrigen Antikörpertitern auf. Der Hauptnachteil ist die mangelnde Sensitivität für IgM. Obwohl IgM TeNT nicht neutralisieren kann, führen IgM-Moleküle zu falschpositiven Titern im Hämagglutinationstest (WHO, 1993).

\subsubsection{Toxinbindungsinhibitionstest}

HENDRIKSEN et al. (1989) führten erstmals einen Toxinbindungsinhibitionstest (ToBi) durch. Der ToBi kann als modifizierter ELISA angesehen werden. Im Gegensatz zum ELISA erfolgt hier die Detektion von ungebundenem Toxin in einem Toxin-Antitoxin-Gemisch. Da die Detoxifizierung des Toxins nicht seine antigenen Epitope modifiziert, wird beim ToBi 
Toxoid anstatt des reinen Toxins verwendet. Der ToBi zeigt eine bessere Korrelation zum Neutralisationstest als herkömmliche ELISAs (WHO, 1993). MATOS et al. (2002) standardisierten und validierten einen Toxinbindungsinhibitionstest zum Vergleich von humanern Diphtherie-Tetanus- und Diphtherie-Tetanus-Pertussis-Impfstoffen. Als Referenzmethode diente der Neutralisationstest. Die Ergebnisse für tetanusspezifische Antikörper korrelierten gut mit dem Neutralisationstest.

\subsubsection{ELISA}

Bei einem indirekten ELISA wird Tetanustoxoid an die Plastikoberfläche einer Mikrotiterplatte gebunden. Der hinzugegebene Antikörper im Patientenerum bildet einen Komplex mit dem Antigen. Die Visualisierung erfolgt durch Zugabe eines enzymgekoppelten Sekundärantikörpers. Dieser bindet an den Antigen-Antikörperkomplex. Nach Zugabe eines spezifischen Substrates wird der enzymvermittelte Farbumschlag des Antigen-AntikörperSekundärantikörper-Komplexes sichtbar. Die Reaktion wird nach einer definierten Reaktionszeit abgestoppt. Die Extinktionen der Reaktionsprodukte können mit einem ELISAReader im sichtbaren Spektrum verfolgt werden (Anonym eff $_{\text {, }} 2000$ ). Wie der passive Hämagglutinationstest zeigt auch der ELISA im niedrigtitrigen Bereich gehäuft falschpositive Resultate. Die Ergebnisse modifizierter ELISAs, sogenannter „antigen competition ELISA“, korrelieren dagegen gut mit dem Neutralisationstest (WHO, 1993).

Die Etablierung leistungsfähiger und sensitiver ELISAs könnte zur Reduzierung der Tierversuche bei der Impfchargentestung für Tetanustoxoidimpfstoffe beitragen (Gupta und Siber, 1996). Bereits SEDGWICK et al. (1983) entwickelten einen ELISA mit einer Testdauer von 2,5 h und einer Sensitivität von 0,1-6 IE/ml. Bei Vergleichsuntersuchungen zwischen einem modifizierten passiven Hämagglutinationsassay (PHA), ELISA und Counterimmunelektrophorese zeigten sich PHA und ELISA hinsichtlich der Sensitivität und Reproduzierbarkeit vergleichbar und der Immunelektrophorese überlegen. Im Gegensatz zur Immunelektrophorese war mit PHA und ELISA die Detektion hochtitriger Seren möglich. Die modifizierte passive Hämagglutination zeigte eine Korrelation zum Neutralisationstest. Der protektive tetanusspezifische Antikörpergehalt wurde mit 0,1 IU/ml Serum angegeben (Pitzurra et al., 1983).

Die ECVAM ECb $_{\mathrm{b}}$ (2000) entwickelte einen ELISA zur Impfstofftestung mit einer guten Korrelation zum Neutralisationstest. Bei einer akzeptablen Standardabweichung und Präzision 
der Konfidenzintervalle der Triplikate betrug die Korrelation zum ToBi 0,96 (0,925-0,986) sowie die Korrelation vom ToBi zum NT 0,92 (0,88-0,97). In den USA ist ein indirekter ELISA zur Testung von equinem Antitoxin und der Bestimmung der Antigenität von Tetanustoxoid im Serum vakzinierter Meerschweinchen zugelassen (US Departement of Agriculture $_{a, b}$, 1992). Mit einer Kombination von indirektem ELISA und Partikelagglutinationstest konnten auch niedrige Antikörpergehalte bestimmt werden (Coplu et al., 2004). DEMING et al. (2002) entwickelten einen Doppelantigen-ELISA auf getrockneten Filterpapieren. Mit diesem Test konnten sie zuverlässig niedrigtitrige Proben bestimmen.

\subsubsection{Radioimmunoassay}

Beim Radioimmunoassay werden tetanusspezifische Antikörper durch Inkorporation in isotopengebundenes Antiglobulin quantifiziert. Der RIA ist ein teures und personalintensives Verfahren. Auf Grund der besonderen Gesundheitsgefährdung, die beim Umgang mit radioaktiven Isotopen ausgeht, ist der RIA trotz seiner hohen Sensitivität und Reproduzierbarkeit wenig verbreitet (Huet, 1989).

\subsubsection{Fluoreszenzassay}

Die Entwicklung eines indirekten Multiplex Fluoreszenzassays (MFA) zur Detektion postvakziner Immunantworten nach Tetanusimpfung zeigten einen Cut off von 0,1 IU/ml. Der Korrelationskoeffizient MFA/ELISA betrug 0,96. Im Gegensatz zum ELISA ist der MFA kostensparender und weniger zeitintensiv (Pickering et al., 2002)

\subsubsection{Latexagglutination und Geldiffusionstechniken}

Beide Methoden sind preiswert und einfach. Sie zeichnen sich durch eine geringe Sensitivität aus und sind daher nicht zur Antikörperbestimmung geeignet (Galazka, 1975). 
Die oben beschriebenen Verfahren sind nur in unzureichendem Maße zur routinemäßigen Überprüfung des Impferfolges nach Tetanusvakzinierung geeignet: methodisch zu aufwändig und langwierig, ethisch problematisch, kosten-/personalintensiv, niedrige Sensitivität und/oder Spezifität bzw. hohe gesundheitliche Gefährdung des Personals. Der Zweck dieser Arbeit war es, ein geeignetes Laborverfahren zur praxisgerechten, schnellen und kostengünstigen Überprüfung des Tetanusantitoxingehaltes bei Pferden zu entwickeln. 


\section{$3 \quad$ Allgemeine Materialien und Methoden}

Die praktischen Aspekte dieser Arbeit gliederten sich in zwei Teile. Im ersten Teil sollte ein geeignetes Laborverfahren zur Bestimmung des tetanusspezifischen Antitoxingehaltes im Pferdeblut bestimmt werden. Der zweite Teil beinhaltete die praxisnahe Erprobung des Tests in Feldversuchen.

3.1 Allgemeine Angaben über das Untersuchungsgebiet

Die Felduntersuchungen wurden im Zeitraum von August 2004 bis September 2005 durchgeführt.

\subsubsection{Geographische und ackerbauliche Parameter des Untersuchungsgebietes}

Das Untersuchungsgebiet befindet sich in den Kammlagen des Thüringer Waldes auf einer Höhe von 650 m über NN.

Die vorherrschende Bodenart des Untersuchungsgebietes ist Bergschlufflehm aus flachgründigen, feinverwitterten Schieferböden. Der Standorttyp wird mit V8a/V9a angegeben. Die Ackerzahl schwankt in Abhängigkeit von Plateau-, Hang- oder Tallagen zwischen 16-24. Der durchschnittliche pH-Wert beträgt 5,0. Die letzten Bodenkalkungen wurden vor 1990 durchgeführt.

Die beweideten Gebiete sind Dauergrünland oder in geringem Maße, in den 80er Jahren des vergangenen Jahrhunderts, angesäte Grünländer. Dominierende Futtergräser der Dauergrünländer sind Rotstraußgras und Rotschwingel. Auf angesätem Grünland wachsen vorrangig Knaulgras und Wiesenlieschgras. Auf Grund fehlender Staunässe in den beweideten Gebieten kommen Giftpflanzen, wie Herbstzeitlose, Hahnenfußgewächse und gefleckter Schierling praktisch nicht vor (Hochberg, 2005). 


\subsubsection{Haltungszweck der Untersuchungstiere}

Die Haltung der Pferde erfolgt nach folgenden Gesichtspunkten:

- Zucht nach Rassetyp Haflinger

- Ausbildung von Tieren für den Reit- und Fahrsport, Touristik

- Gewinnung von Stutenmilch zur Lebensmittel- und Kosmetikherstellunga

- Gewinnung von Pregnant Mare Serum Gonadotropin (PMSG) aus dem Serum tragender Stuten

a) Laktierende Stuten werden ab dem 50. bis 60. Laktationstag zweimal pro Tag maschinell gemolken. Dazu werden die Fohlen zwei Stunden vor der Melkzeit von ihren Müttern separiert.

b) Zur Gewinnung von PMSG wurde den Stuten zwischen dem 20. und 100. Trächtigkeitstag an mehreren Tagen in der Woche Vollblut durch Punktion der V. jugularis entnommen. Zur Aufrechterhaltung des Hämatokrites erfolgte die intravenöse Rückführung der festen Blutbestandteile der Abnahme des jeweiligen Vortages. Die in dieser Arbeit untersuchten Stuten befanden sich außerhalb des für die PMSG-Gewinnung relevanten Trächtigkeitszeitraumes und wurden daher nicht geblutet.

\subsubsection{Haltung und Fütterung}

Die Haltung der Pferde erfolgte in der Vegetationszeit auf extensiv genutzten Mittelgebirgsweiden. Auf Grund günstiger Witterung und entsprechendem Futterangebot konnten die Tiere im Untersuchungszeitraum bis zum Dezember auf den Weideflächen gehalten werden. Während der Wintermonate und des zeitigen Frühjahres werden die Pferde in Laufställen zu je 30-40 Tieren gehalten. Die Einstallung erfolgte mit Stroh in Tiefstreu. Hochtragende und frischlaktierende Stuten mit ihren Fohlen wurden in großzügigen Laufställen, sowie stundenweise auf gestütsnahen Koppeln gehalten.

Die Stallfütterung erfolgte leistungsabhängig mit Rauh- und Kraftfuttermitteln. Heu wird auf eigenen Mähweiden produziert. Salzlecksteine standen im Stall und auf den Koppeln zu jeder Zeit zur Verfügung. Wasser wurde in den Stallungen über Selbsttränken und auf den Weiden in Sammeltränken angeboten. 


\subsection{Blutentnahme; Aufbereitung und Rekonstitution der Blutproben}

Die Pferde wurden vor Ort am Halfter fixiert. Die Blutproben wurden durch Stauung und Punktion und der V. jugularis externa entnommen und für 2-4 h bei RT aufbwahrt.

Die Blutproben wurden fünf min bei $600 \mathrm{~g}$ in einem Festwinkelrotor zentrifugiert. Serum bzw. Plasma wurde durch Abpipettieren von den zellulären Blutbestandteilen getrennt. Die Lagerung erfolgte in $1,5 \mathrm{ml}$-Aliquoten in Kryoröhrchen bei $-20^{\circ} \mathrm{C}$.

Vor Versuchsbeginn wurden die Serum- und Plasmaproben im Wasserbad bei $37^{\circ} \mathrm{C}$ schonend und zügig aufgetaut. Zur Beseitigung der Phasenverteilung wurden die Proben dreimal über Kopf gekippt.

3.3 Gewinnung der Milchproben; Aufbereitung und Rekonstitution der Milchproben

Die Gewinnung der Milchproben erfolgte am Morgen vor der ersten Melkzeit. Zu diesem Zweck wurden die Euter mit frischem Wasser gereinigt und mit einem sauberen Tuch abgetrocknet. Die ersten drei Striche jeder Euterhälfte wurden verworfen. Anschließend wurden aus jeder Euterhälfte manuell ca. $20 \mathrm{ml}$ Milch als Sammelgemelk in sterile $50 \mathrm{ml}-$ Zentrifugenröhrchen abgemolken. Die kurzzeitige Zwischenlagerung erfolgte bei $4{ }^{\circ} \mathrm{C}$.

Die Arbeitsanweisung zur Aufarbeitung von Milch- und Kolostrumproben wurde von WINTERHOFF (2000) adaptiert. Die Milchproben wurden mit je 0,05 mg/ml Renin versetzt und zwei bis vier Stunden bei $37^{\circ} \mathrm{C}$ im Wasserbad inkubiert. Nach Einsetzen der Gerinnung und Dicklegung der Milch wurden die Proben 10 min bei $600 \mathrm{~g}$ in einem Festwinkelrotor zentrifugiert. Die Molke wurde dekantiert und durch einen bakteriendichten Filter mit niedriger Proteinbindungsaffinität mit einer Porenweite von 0,2 $\mu \mathrm{m}$ filtriert. Die Lagerung erfolgte in sterilen, verschließbaren Glasröhrchen bei $-20^{\circ} \mathrm{C}$.

Vor Versuchsbeginn wurden die Milchproben im Wasserbad bei $37^{\circ} \mathrm{C}$ schonend und zügig aufgetaut. Zur Beseitigung der Phasenverteilung wurden die Proben dreimal über Kopf gekippt. 


\subsection{Vakzinierungen}

Die Vakzinierungen der Pferde wurde durch tiefe intramuskulöse Injektion jeweils einer Impfstoffdosis verabreicht. Die Boosterungsimpfungen der erwachsenen Pferde sowie die Grundimmunisierung der Jährlinge wurden mit Influenza/Tetanus-Kombinationsimpfstoff durchgeführt. Zur Grundimmunisierungen der Fohlen wurde monovalenter Tetanusimpfstoff verwendet (Tab. 4).

\begin{tabular}{|c|c|c|}
\hline Tiergruppe & Zeitpunkt & Impfstoff \\
\hline Jungstuten & $\begin{array}{c}\text { 1. und 2. Grundimmuni- } \\
\text { sierung nach 1. Lebensjahr }\end{array}$ & $\begin{array}{c}\text { Duvaxyn IE-T Plus }{ }^{\circledR} \text { (Fort } \\
\text { Dodge) }\end{array}$ \\
Altstuten & Boosterung & April/Kalenderjahr \\
& Duvan IE-T Plus ${ }^{\circledR}$ (Fort \\
& Dodge) \\
Saugfohlen & 1. und 2. Grundimmuni- & Equilis Tetanusvaccine $^{\circledR}$ \\
& sierung; 3/4. Lebensmonat & (Intervet) \\
\hline
\end{tabular}

Tab. 4: Vakzinierungschema

\subsection{Statistische Auswertung}

Die statistische Auswertung erfolgte mittels Microsoft Excel ${ }^{\circledR} 2000$. 


\section{$4 \quad$ ELISA}

\subsection{Materialien und Methoden}

\subsubsection{ELISA - Konzeption}

Die Konzipierung des ELISA erfolgte auf Grundlage der DIN 58967-10/-30 (Anonym (A, $_{\text {, }}$ 2000).

\subsubsection{Coaten und Blocken der Mikrotiterplatten}

96-well-Mikrotiterplatten wurden über Nacht bei $4{ }^{\circ} \mathrm{C}$ mit $100 \mu \mathrm{l} /$ well Tetanustoxoidstandard. Das Toxoid wurde in einer Konzentration von $1 \mathrm{Lf} / \mathrm{ml}$ in Karbonat-Bikarbonatpuffer pH 9,2 eingesetzt. Nach Entfernen des Puffers wurden die Platten dreimal mit jeweils $300 \mu$ PBS gewaschen. Die nichtbesetzten Bindungsstellen der Wells wurden anschließend mit je $300 \mu \mathrm{l}$ 0,1 \% BSA/PBS blockiert. Nach Entfernen des Blockpuffers wurden die Mikrotiterplatten dreimal mit jeweils $300 \mu$ l PBS gewaschen.

\subsubsection{Durchführung des ELISA}

Die Mikrotiterplatten wurden fünf Minuten bei RT äquillibriert. Anschließend erfolgte die Zugabe der Negativkontrolle (PBS), der Positivkontrolle (10 IE/ml Equine-IgG-Standard in PBS) sowie der Serumproben (1:100 in PBS). Die Proben wurden in Triplikaten als $100 \mu \mathrm{l}-$ Aliquote eingesetzt. Die Inkubation erfolgte bei $37^{\circ} \mathrm{C}$ für eine Stunde. Nach Entfernen der Proben wurden die Kavitäten dreimal mit jeweils $300 \mu \mathrm{l}$ PBS gewaschen. Danach wurden je $300 \mu \mathrm{l} /$ Well Sekundärantikörper (HRP-konjugierter Equine-Anti-IgG) in einer Konzentration von 1:10000 in PBS zugegeben. Die Inkubation erfolgte für Stunde bei RT im Dunkeln. Nach Entfernen des Sekundärantikörpers wurden die Platten zweimal mit jeweils $300 \mu l$ 0,1 \% Tween 20/PBS pH und dreimal mit jeweils $300 \mu$ PBS gewaschen. Die enzymatische Reaktion des meerrettichperoxidasegekoppelten Konjugates wurde durch Zugabe von 100 $\mu \mathrm{l} /$ Well OPD in Zitrat-Karbonatpuffer pH 5,0 visualisiert. Die Inkubation erfolgte für 15 min bei RT im Dunkeln. Durch Zusatz von jeweils 50 l/Well $2 \mathrm{M} \mathrm{H}_{2} \mathrm{SO}_{4}$ wurde die Reaktion 
abgestoppt. Innerhalb von 20 min nach Beendigung des ELISA wurden die Extinktionen bei 490/630 nm mit einem ELISA-Reader bestimmt.

\subsubsection{Erstellung der Standardkurve und des Algorhythmus}

\subsubsection{Verwendung von Toxin}

Die eingesetzte Toxinkonzentration zum Coaten der Mikrotiterplatten betrug 0,1 mg/ml Karbonat-Bikarbonatpuffer pH 9,2. Die Standardkurve wurde unter Verwendung des AntiTetanus-IgG-Standards erstellt. Die Standards wurden in PBS angesetzt. Folgende Verdünnungen wurden als Triplikate getestet: 0,05 IE/ml, 0,1 IE/ml, 0,25 IE/ml, 0,5 IE/ml, 0,75 IE/ml, 1 IE/ml, 2,5 IE/ml, 5 IE/ml, 7,5 IE/ml, 10 IE/ml, 25 IE/ml, 50 IE/ml. Die Durchführung erfolgte analog der Arbeitsanleitung Kapitel 4.1.3.

\subsubsection{Verwendung von Tetanustoxoid}

Die verwendete Tetanustoxoidkonzentration zum Coaten der Mikrotiterplatten betrug $1 \mathrm{Lf} / \mathrm{ml}$ Karbonat-Bikarbonatpuffer pH 9,2. Die weitere Verfahrensanweisung erfolgte analog Kapitel 4.1.4.1.

4.1.5 Prüfung auf Verwendbarkeit von Serum und Plasma mit verschiedenen Antikoagulanzien

Zur Prüfung auf Verwendbarkeit verschiedener Gerinnungshemmer wurden EDTA-, Heparin, Zitrat- und Serumproben von jeweils drei zufällig ausgesuchten Tieren gegeneinander in einem Versuchsansatz bestimmt. Die Probenverdünnung betrug in jedem Fall 1:100 mit PBS. Die Prüfung erfolgte mittels t-Test $(\alpha=0,05)$. 


\subsubsection{Ermittlung der optimalen Serumverdünnung}

Zur Bestimmung der optimalen Serumverdünnung wurden Serumproben zweier Altstuten mit PBS in folgenden Verdünnungsstufen eingesetzt: unverdünnt, 1:10, 1:50, 1:100, 1:250, 1:500, 1:750, 1:1000. Der ELISA wurde analog der gültigen Arbeitsanweisung durchgeführt.

\subsubsection{Ermittlung des Interassay- und Intraassayvarianzkoeffizienten}

Die Interassayvarianz zeigt den Grad der Reproduzierbarkeit von Messergebnissen einer Probe bei einem definierten Testverfahren an verschiedenen Messtagen. Die Bestimmung der Interassayvarianz erfolgte anhand der messtäglichen Bestimmung des IgG-Standards. Die Einstellung der Arbeitskonzentration von 10 IE/ml mit PBS erfolgte vor jeder Bestimmung neu. Der Berechnung liegen 48 Messwerte (je 3 Parallelen pro Versuch) an 16 Messtagen zu Grunde. Die Varianz wurde nach folgender Formel berechnet:

$$
\begin{aligned}
\mathrm{V}=\mathrm{S} / \mathrm{x} \text { x } 100(\%) \quad \mathrm{x} & =\text { arythmetischer Mittelwert aller Messwerte } \\
\mathrm{S} & =\text { Standardabweichung der Messwerte }
\end{aligned}
$$

Die Intraassayvarianz gibt Aufschluss über die Messwertstreuung einer Probe innerhalb eines Versuchsansatzes. Die Bestimmung wurde mit zwei verschiedenen Serumproben (1:100Verdünnung) in vier Parallelen durchgeführt. Die Berechnung der Intraassayvarianz erfolgte analog der oben genannten Formel.

\subsubsection{Prüfung auf Kreuzreaktivitäten}

Zur Prüfung der Spezifität wurden C. botulinum-Toxine A, B, C und D im ELISA getestet. Da Arbeiten mit intaktem Botulinum-Toxinen gesetzlich restringiert sind, wurden diese Versuche im Institut für Tropentierhygiene der Universität Göttingen durchgeführt. Jeweils 24 Kavitäten einer Mikrotiterplatte wurden mit $10 \mu \mathrm{g} / \mathrm{ml}$ C. botulinum-Toxin A, B, C bzw. D in Karbonat-Bikarbonatpuffer $\mathrm{pH} 9,2$ über Nacht bei $4{ }^{\circ} \mathrm{C}$ an die Mikrotiterplatten gecoatet. Nach Spülen der Platten wurden diese bis zur weiteren Verwendung bei $-20{ }^{\circ} \mathrm{C}$ gelagert. Die 
Durchführung des Testes erfolgte analog der Arbeitsanweisung für den ELISA (Kapitel 4.1.3). Die Auswahl der vier Kontrollseren erfolgte nach Zufallsprinzip.

\subsubsection{Ermittlung des Cut off und des Schwellenwertes}

Der Cut off und der Schwellenwert wurden anhand der tetanusspezifischen Antikörpertiter im Serum nicht grundimmunisierter Jährlinge festgestellt. Untersucht wurden 10 Jungstuten im Alter von 10-15 Monaten zwischen Januar und März 2005 im Abstand von 21-30 Tagen. 14 Tage vor Beginn der Immunisierungen wurden alle Tiere der Prüfungsgruppe entwurmt $\left(\right.$ Paramectin $^{\odot}$ ).

\subsubsection{Ermittlung der Sensitivität}

Die Bestimmung der Sensitivität des Testes erfolgte anhand der Serumtiterbestimmungen immunisierter Altstuten. Das mittlere Alter der Stuten betrug 136,27 Monate (51-208 Monate Schwankungsbreite) bei einer durchschnittlichen Körpermasse von 481 kg (Schwankungsbreite 400-560 kg). Die Probenahme erfolgte von August bis Dezember 2004 im Abstand von 28-34 d. Es handelte sich um 30 Haflingerzuchtstuten. Mit Ausnahme von zwei Tieren befanden sich die untersuchten Stuten im zweiten Trimenion und führten ihr Fohlen im Alter von 3-8 Monaten mit. Die Haltung erfolgte während des Untersuchungszeitraumes ganztägig im Weidebetrieb.

Die Sensitivität wurde nach folgender Formel berechnet (Meyer und Bellwinkel, 1990):

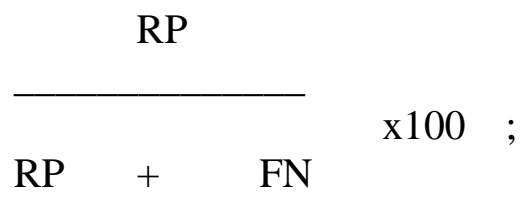

wobei: $\quad$ RP Anzahl richtig positiver Tiere

FN Anzahl falsch negativer Tiere 


\subsection{Materialien und Methoden Milch-ELISA}

\subsubsection{Konzeption}

Die Konzipierung des ELISA erfolgte in Anlehnung an die Arbeitsanweisung für den SerumELISA (Kapitel 4.1.1).

\subsubsection{Coaten und Blocken der Mikrotiterplatten}

Das Coaten und Blocken der Mikrotiterplatten erfolgte mit 1 Lf Tetanustoxoid in KarbonatBikarbonatpuffer pH 9,2 analog Kapitel 4.1.2.

\subsubsection{Durchführung des ELISA}

Mit Ausnahme der Probenaufarbeitung erfolgte die Durchführung analog Kapitel 4.1.3. Die Milchproben wurden vor Testbeginn 1:10 mit PBS verdünnt. Als Negativkontrollen dienten PBS und pasteurisierte 1:100 verdünnte Kuhmilch. Die Kuhmilchkontrolle wurde aus einem handelsüblichen Produkt gewonnen und nach Kapitel 3.3 aufgearbeitet und rekonstituiert. 


\subsection{Ergebnisse}

\subsubsection{Blut-ELISA}

\subsubsection{Toxin-Standardkurve und Algorhythmus}

Die Standardkurve unter Verwendung von TeNT folgte einer annähernd exponentiellen Funktion mit folgender Gleichung: $y=0,0092 e^{8,0738 x}$. Das Bestimmtheitsmaß $R^{2}$ betrug 0,8258 .

\subsubsection{Toxoid-Standardkurve und Algorhythmus}

Der Verlauf der tetanusspezifischen IgG-Standardkurve folgte einer exponentiellen Funktion nach folgendem Algorhythmus und Bestimmtheitsmaß (Abb. 2):

$$
\begin{aligned}
\operatorname{IgG}(\mathrm{IE} / \mathrm{ml}) & =0,0193 \mathrm{e}^{5,478 x} \\
\mathrm{R}^{2} & =\mathbf{9 , 8 2 7}
\end{aligned}
$$

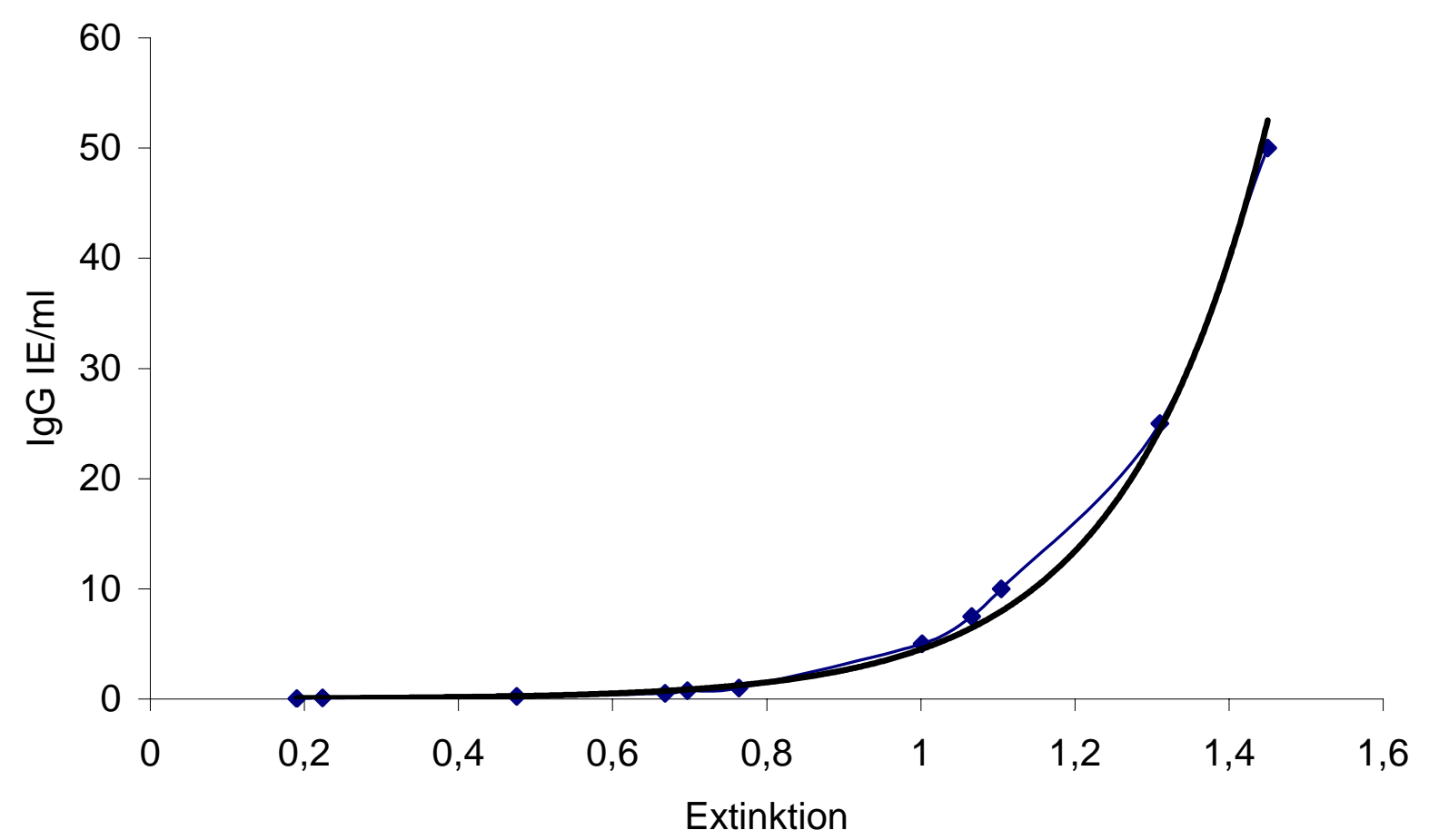

Abb. 2: Standardkurve bei Verwendung von $1 \mathrm{Lf} / \mathrm{ml}$ Tetanustoxoid zum koaten 
4.3.1.3 Verwendbarkeit von Serum- und Plasmaproben

Die Verwendung verschiedener Gerinnungshemmer, bzw. Serumproben in der angegeben Verdünnung, hatte keinen signifikanten Einfluss auf die Anti-Tetanus-IgG-Gehalte $(\mathrm{p}<0,05)$ der Proben. Für die Untersuchungen innerhalb dieser Studie wurden ausschließlich Serumproben verwendet.

\subsubsection{Ermittlung der optimalen Serumverdünnung}

Abb. 3 zeigt die Kurvenverläufe bei den gewählten Serumverdünnungen (Tab. 5). Die Auswahl der optimalen Serumverdünnung erfolgte im linearen Bereich der Kurve. Bei der höher titrigen Probe (Stute 1) umfasst der lineare Bereich die Verdünnungsstufen 1:1001:500. In der niedriger titrigen Probe (Stute 2) umfasst der lineare Bereich die Verdünnungsstufen 1:50-1:250. Verdünnungsstufen, die sowohl hohe, als auch niedrige Serumtiter zuverlässig anzeigen können, sind die 1:100- und die 1:250-Verdünnung. Zur Minimierung zufälliger Fehler durch pipettieren zu kleiner Volumina wurde die 1:100Verdünnungsstufe für den ELISA ausgewählt.

\begin{tabular}{|c|c|c|}
\hline Verdünnungsstufe & Stute 2 & Stute 1 \\
\hline Unverdünnt & 1,40505 & 1,9623 \\
$1: 10$ & 1,4963 & 1,98755 \\
$1: 50$ & 1,02705 & 1,7918 \\
$1: 100$ & 0,7068 & 1,47255 \\
$1: 250$ & 0,3663 & 0.9053 \\
$1: 500$ & 0,18355 & 0,52455 \\
$1: 750$ & 0,1098 & 0,3273 \\
$1: 1000$ & 0,1353 & 0,2588 \\
\hline
\end{tabular}

Tab. 5: Ermittlung der optimalen Serumverdünnung 


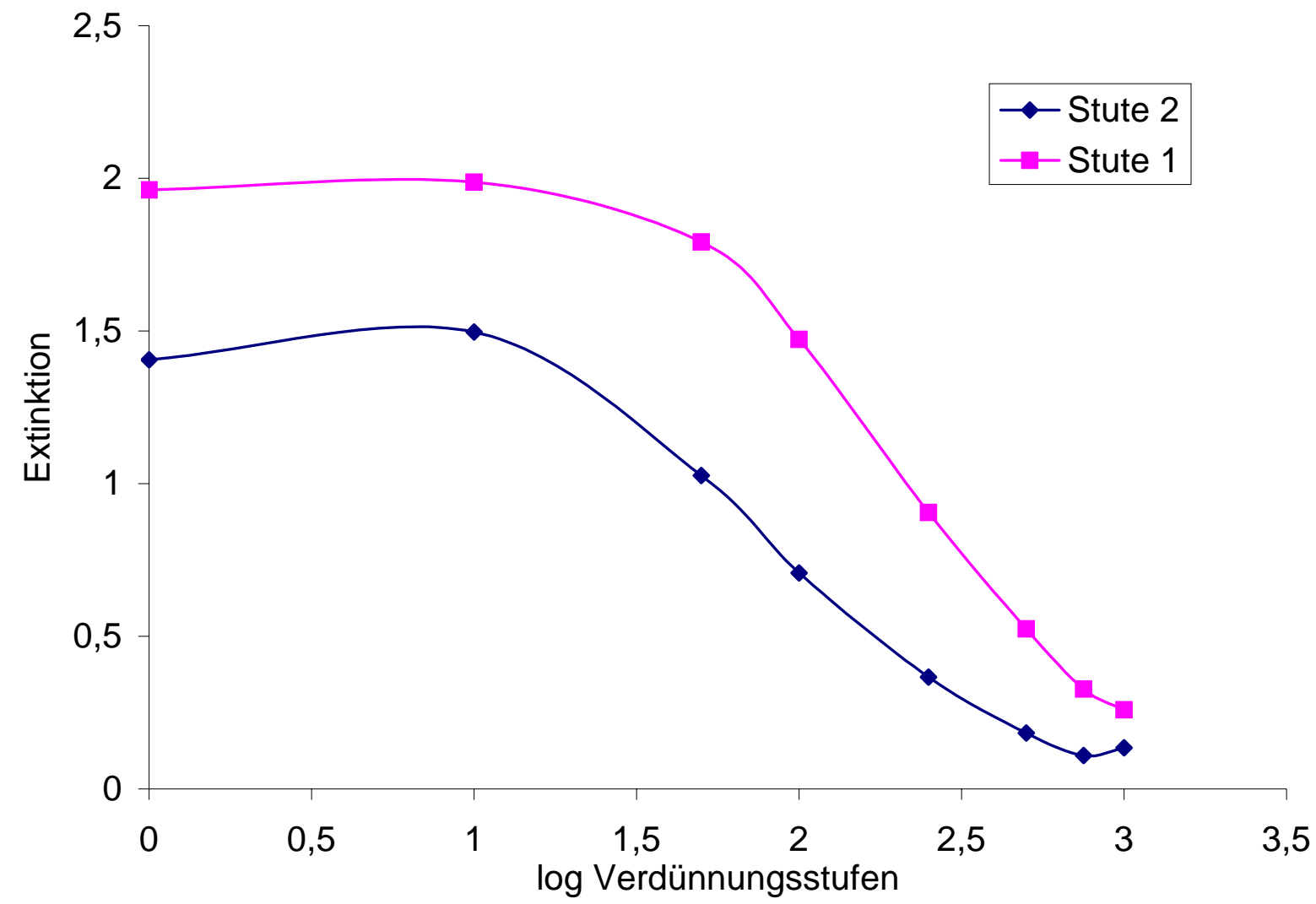

Abb. 3: Ermittlung der optimalen Serumverdünnung

\subsubsection{Intraassayvarianzkoeffizient}

Die Intrassayvarianz für den vorliegenden Test betrug im Mittel 4,61 \%. Tab. 6 gibt einen Überblick über die Daten der Intraassayvarianzkoeffizientenbestimmung.

\begin{tabular}{|c|c|l|}
\hline Stute 1 & Stute 2 & \\
\hline 1,397 & 0,741 & \\
1,496 & 0,766 & \\
1,53 & 0,742 & \\
1,545 & 0,688 & \\
1,49225 & 0,7265 & Mittelwert \\
0,066835 & 0,03442383 & Standardabweichung \\
4,48 & 4,74 & Intraassayvarianzkoeffizient \\
\hline
\end{tabular}

Tab. 6: Darstellung des Intraassayvarianzkoeffizienten 


\subsubsection{Interassayvarianzkoeffizienz}

Die Berechnung des Interassayvariationskoeffizient ergab für diese Methode den Wert von $11,01 \%$.

\subsubsection{Prüfung auf Kreuzreaktionen mit C. botulinum-Toxintypen A, B, C, D}

Es konnten keine Kreuzreaktivitäten der tetanusspezifischen Antikörper gegen C. botulinumToxinypen in den Serumproben bestimmt werden $(\mathrm{p}<0,05)$.

\subsubsection{Bestimmung des Cut off und des Schwellenwertes}

Der Cut off berechnete sich aus der dreifachen Standardabweichung zuzüglich des arithmetischen Mittelwertes. Der Cut off bestimmt die Unterscheidungsgrenze, bei der vernachlässigbar falsch positive und falsch negative Untersuchungsergebnisse zwischen positiven und negativen Proben bestimmt werden. Messwerte, die zwischen Cut off und Schwellenwert liegen, werden als zweifelhaft eingestuft, wobei der Schwellenwert aus der Summe des arithmetischen Mittels und der einfachen Standardabweichung berechnet wurde (Grosse-Herrenthey, 2004).

\begin{tabular}{lc} 
Mittelwert & $0,054515 \mathrm{IE} / \mathrm{ml}$ \\
Standardabweichung & 0,001775517 \\
Spannweite $\left(\mathrm{x}_{\max }-\mathrm{x}_{\min }\right)$ & 0,11436574 \\
& \\
\hline Schwellenwert & $0,07227081 \cong 0,072 \mathrm{IE} / \mathrm{ml}$ \\
Cut off & $0,1077812 \cong 0,11 \mathrm{IE} / \mathrm{ml}$
\end{tabular}

Tab. 7: Berechnung des Schwellenwertes und des Cut off

Messwerte, die in diesem ELISA größer als 0,11IE/ml gemessen wurden, sind laut Definition als seropositive Titer (richtig positiv) einzustufen. Messwerte zwischen 0,072 IE/ml und 0,11 IE/ml sind als fraglich (falsch positiv oder falsch negativ) einzuschätzen. Messwerte, die kleiner als 0,072 waren, sind als richtig negativ zu interpretieren (Tab. 7). 


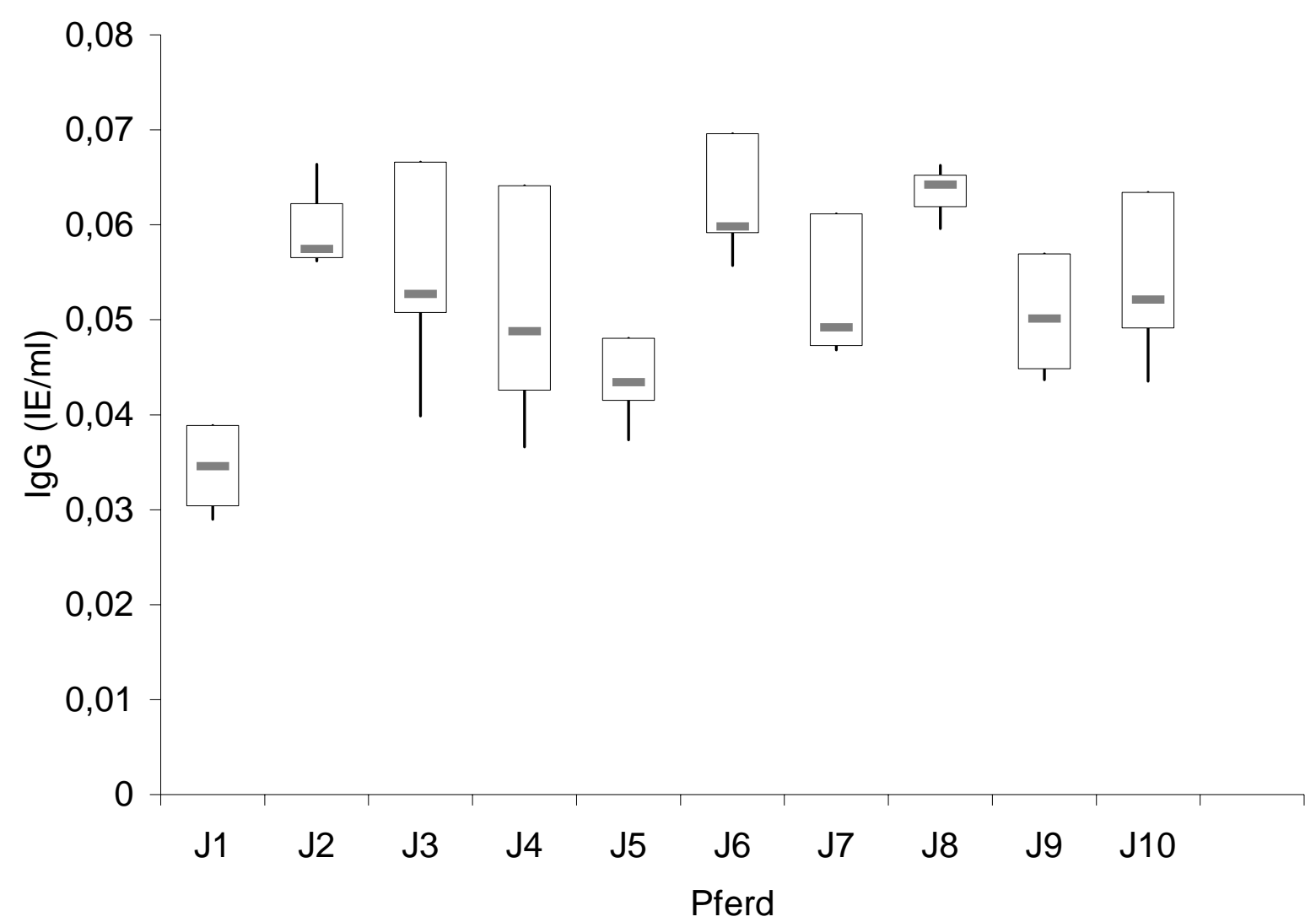

Abb. 4: Boxplot der Serumtiter bei nicht immunisierten Jährlingen

Die Darstellung der Antitoxingehalte bei den Einzeltieren (Abb. 4) veranschaulicht deren individuelle Schwankungsbreite. Mit Ausnahme von Tier 1 (J1) besaßen alle anderen Werte um 0,05-0,07 IE/ml.

\subsubsection{Bestimmung der Sensitivität}

Die Daten wurden in drei Gruppen unterteilt: richtig negativ $\leq$ 0,072 IE/ml, grenzwertig 0,072 $\mathrm{IE} / \mathrm{ml}-0,11 \mathrm{IE} / \mathrm{ml}$ und richtig positiv > 0,11 IE/ml (Abb. 5).

Die Spannweite der Messergebnisse $\left(\mathrm{R}=\mathrm{x}_{\max }-\mathrm{X}_{\min }\right)$ belief sich auf 86,12 (Lorenz, 1996). 1,3 $\%$ (2) aller Messergebnisse waren $\leq 0,072$ IE/ml. 8,67 \% (13) der Messdaten lagen grenzwertig zwischen Schwellenwert und Cut off. 86,67 \% (130) der Ergebnisse ergaben Titer $\geq 0,11 \mathrm{IE} / \mathrm{ml}$.

Die Berechnung der Sensitivität ergab einen Wert von 89,655. Das heißt, die Methodik konnte in 89,655 \% der untersuchten Seren von nachweislich immunisierten Pferden tetanusspezifische Titer erfassen. 


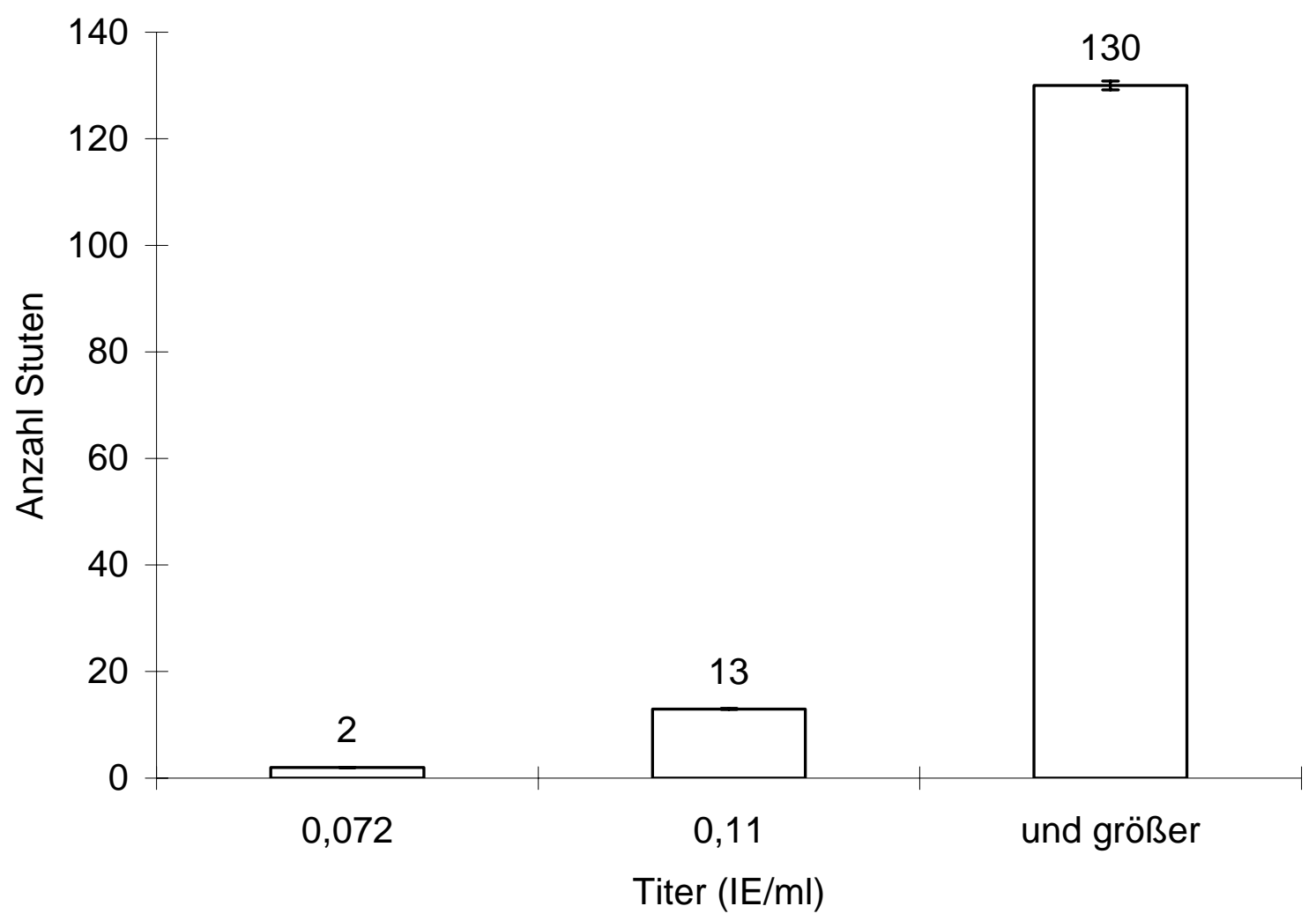

Abb. 5: Histogramm negativer, grenzwertiger und protektiver Titer bei immunisierten Stuten

\subsubsection{Milch-ELISA-Konzeption und Durchführung}

Die Durchführung des Milch-ELISA orientierte sich im Wesentlichen an der Arbeitsanweisung für den Serum-ELISA. Entsprechend der Probenmatrix, mussten die Milchproben nach einem anderem Regime aufgearbeitet werden (Kapitel 3.3). Der Einsatz im ELISA erfolgte in einer 1:10 Verdünnung mit PBS. In jedem Testdurchlauf wurden zwei verschiedene Negativkontrollen jeweils in Triplikaten mitgeführt. Die erste Negativkontrolle war PBS. Zum Ausschluss matrixassoziierter Unspezifitäten wurde eine Kontrolle aus pasteurisierter handelsüblicher zehnfach verdünnter Kuhmilch mitgeführt. Die Aufarbeitung der Kuhmilchprobe erfolgte analog Kapitel 3.3. Die Positivkontrolle (10 IE/ml) wurde ebenfalls in Triplikaten mitgeführt. 


\subsection{Diskussion}

\subsubsection{Blut/Serum-ELISA}

Die Referenzmethode zum Antitoxinnachweis nach Immunisierung mit Tetanustoxoidimpfstoffen ist der in vivo-Maus-Challange-Test (Anonym $\mathrm{a}, 2002$ ). Tierversuche sind streng reglementiert und bedürfen der Genehmigung der Ethikkommissionen. Sie sind daher nicht für die routinemäßige Überprüfung des Antitoxingehaltes geeignet. In den letzten Jahren wurden vermehrt Untersuchungen angestrengt, den Einsatz und Umfang von Tierversuchen zur Wirksamkeitsüberprüfung von Impfstoffen in der Human- und Veterinärmedizin zu reduzieren (Metz et al., 2002; ECVAM, 2000). ROSSKOPF-STREICHER et al. (2003, 2004) entwickelten einen indirekten kompetitiven ELISA zur Bestimmung der $\varepsilon$-Toxin-Komponente bei C. perfringens als Ersatz zum in vivo-Maus-Test bei der Impfchargenkontrolle. Im Jahr 2004 entwickelte ROSSKOPF einen Doppelantigen-ELISA zur Wirksamkeitsprüfung von Tetanusimpfstoffen bei Pferden und Schafen. Mit Hilfe des Doppelantigen-ELISA konnten niedrigtitrige Proben zuverlässig bestimmt werden.

Zweck dieses Verfahrens war die in vitro-diagnostische quantitative Bestimmung von tetanusspezifischem IgG in equinem Serum bzw. Plasmaproben. In der Praxis soll dies in der Regel die Überprüfung des Tetanus-Impfstatus eines Tieres bedeuten.

Der ELISA ist die Methode der Wahl zur Bestimmung des Antikörpergehaltes einer Substanz. Er wurde in den frühen 70er Jahren des letzten Jahrhunderts als Alternative zum Radioimmunoassay entwickelt (Avrahameas und Ternynck, 1998). Beim ELISA wird die hohe Spezifität von Antikörpern mit der Empfindlichkeit spektroskopischer Methoden vereint. In diesem Verfahren werden Antigene oder Antikörper eingesetzt, die an einfach zu bestimmende Enzyme mit hoher Wechselzahl kovalent gebunden sind. Besonders geeignete Enzyme sind Alkalische Phosphatase und Meerrettichperoxidase. Alkalische Phosphatase spaltet in alkalischem Milieu p-Nitrophenylphosphat zum gelben p-Nitrophenol. Substrate der Meerettichperoxidase sind Diaminobenzidin, oder o-Phenyldiamin (Wilson und Goulding, 1991). Art und Aufbau des vorliegenden ELISA wurde nach DIN 58967-10 und 58967-30 $\left(D_{\text {IN }}\right.$, , 2000) konzipiert. Dieser Test ist ein nichtkompetitiver indirekter ELISA. Das Antigen wird hierbei nicht direkt in der Probe, sondern indirekt durch Bindung seines in der 
Probe befindlichen korrespondierenden Antikörpers bestimmt. Daher konkurrieren die Reaktionspartner nicht um das Antigen. Die Antigen-Antikörperreaktion verläuft quantitativ. Im Gegensatz zum sigmoidalen Kurvenverlauf beim kompetitiven ELISA besteht beim inkompetitiven ELISA eine direkte Proportionalität zwischen der Antikörperkonzentration und Extinktion (Meyer und Bellwinkel, 1990). WINSNES et al. (1989) konnten bei Methodenvergleichsuntersuchungen mit humanen Tetanusimmunglobulinpräparationen die größte Korrelation beim indirekten ELISA zum NT nachweisen (0,93-0,97).

Bei diesem Verfahren wurde der nachzuweisende Reaktionspartner (tetanusspezifisches equines IgG) durch an eine feste Phase gekoppeltes korrespondierendes Antigen (Tetanustoxoid) gebunden. In einem folgenden Reaktionschritt wurde der gebundene Antikörper der Serumprobe durch Zugabe eines enzymatisch gekoppelten, zum Primärantikörper korrespondierenden, Sekundärantikörpers (anti-equine IgG) nachgewiesen. Der Sekundärantikörper war ein im Kaninchen produzierter polyklonaler Antikörper gegen equines IgG. Die Quantifizierung des tetanusspezifischen IgG-Gehaltes wurde durch Vergleich der gemessenen Extinktionswerte der Proben mit der Standardkurve bestimmt. Die Standardkurve wurde sowohl mit Tetanustoxin als auch mit Tetanustoxoid durchgeführt. Beide Substanzen ergaben exponentielle Kurvenverläufe. WINSNES et al. (1989) konnten keine Unterschiede von Tetanus-Antitoxingehalten im indirekten ELISA bei Verwendung von Toxin- und Toxoid-Konzentrationen von 0,005 - 8,0 Lf/ml feststellen. Auf Grund der hohen Produktkosten beim kommerziellen Bezug von Tetanustoxin sowie der fehlenden Arbeitserlaubnis für Clostridienneurotoxine des Projektpartners fzmb wurde der ELISA in Folge ausschließlich mit Toxoid durchgeführt. Vergleichbare Tests aus der Humanmedizin verwenden sowohl Toxin $\left(\right.$ Anonym $_{c}$, 2003) als auch Toxoid (Anonym ${ }_{d}$, 2003). Verschiedene Arbeiten beschreiben die Bestimmung falsch positiver Werte im niedrigtitrigen Bereich in Größenordnungen um 6 \% bei Seren <0,16 IE/ml (zit. in Winsnes et al., 1989). Zur Überprüfung der Richtigkeit sollten niedrigtitrige Seren im Neutralisationstest überprüft werden.

Die Validierung eines Verfahrens dient der Eignungsprüfung des Testes, um sichere reproduzierbare Ergebnisse zu erhalten. Im Rahmen einer Verfahrensvalidierung können verschiedene Parameter untersucht werden, z. B. Feldstudien und/oder epidemiologische Studien, Methodenvergleichsuntersuchungen, Standardvergleichsuntersuchungen, Ringversuche bzw. Laborvergleichsuntersuchungen, experimentelle Infektionsversuche oder auch Analysen der laborinternen Qualitätskontrolldaten (OIE, 2004). 
Zur Validierung einer diagnostischen Methode zählen die Deklarationen von Störfaktoren, z.

B. Antikoagulantien, Matrixeinflüsse, verabreichte Pharmaka oder

Verdünnungsmedien/Puffer. Eigene Untersuchungen konnten belegen, dass die

Gerinnungshemmer EDTA, Heparin und Zitrat keinen signifikanten Einfluss auf die Höhe des Antitoxingehaltes haben. Diese Beobachtung deckt sich im Wesentlichen mit den Angaben der humanmedizinischen Produkte. Für die folgenden Untersuchungen wurde ausschließlich Serum verwendet. Unter Matrixeinflüssen versteht man Interferenzen mit einem oder mehreren physiologischen Probenbestandteilen. Da nicht ausgeschlossen werden konnte, dass sich verschiedene Pharmaka nachhaltig auf die Bestimmung des Tetanus-Antitoxingehaltes auswirkem könnten, wurde auf die Verwendung von Proben der Pferde verzichtet, die in den letzten sieben Tagen vor der Probenahme medikamentös behandelt waren. Tiere, bei denen ein akuter Erkrankungsfall, z. B. Kolik, zum Zeitpunkt der Probenahme vorlag, wurden ebenfalls nicht berücksichtigt. Die Wahl des Verdünnungsmediums, der Waschpuffer sowie der Waschgänge wurden nach empfohlenen ELISA-Protokollen verschiedener kommerzieller Anbieter übernommen und modifiziert.

Die Probenverdünnung wurde im weiteren Sinn zur Probenmatrix gezählt. Sie kann einen Einfluss auf die Höhe und Reproduzierbarkeit des gemessenen Antitoxingehaltes besitzen. Der Grund dafür könnte das sogenannte Prozonenphänomen/high dose hook effect sein. Dieser Effekt beschreibt den Abfall der Extinktionswerte bei hochtitrigen Proben. Das Phänomen beruht auf einem Überschuss an Antikörpern bei konstantem Antigengehalt. In Folge des Überschusses kommt es zur Auflösung der Präzipitatkomplexe. Nach Überschreiten des Maximalwertes ist die Extinktion damit nicht mehr proportional zum Immunglobulingehalt in der Probe. Die Extinktionen fallen trotz steigender Antikörpergehalte. Die Konsequenz wäre die Verdünnung höher titriger Proben auf proportionale Niveaus bzw. eine Konzentrationserhöhung des festphasengebundenen Tetanustoxoids (Meyer und Bellwinkel, 1990). Die Auswahl der Verdünnungsstufe erfolgte im linearen Bereich der Kurve. In den Versuchen zeigte sich, dass die Serumproben mindestens 1:100 verdünnt werden müssen. Der maximal mögliche Verdünnungsfaktor war 1:250. Zur Minimierung zufälliger Fehler und damit der Präzision durch Pipettieren kleinster Volumina wurde die hundertfache Probenverdünnung für den ELISA ausgewählt. Die Verwendung von isotonischem Verdünnungsmedium mit physiologischem $\mathrm{pH}-$ Wert schien obligat.

Der Cut off ist eine methodenspezifische Größe, die den Unterscheidungswert zwischen seropositiven und seronegativen Proben beschreibt (Anonym $\mathrm{e}_{\mathrm{e}}, \mathrm{2000)}$. Er wurde an der 
negativen Kontrollgruppe (nichtgrundimmunisierte Jährlingsstuten) festgelegt. Er lag im Pferdeassay bei 0,11 IE/ml. Die Weltgesundheitsorganisation (WHO, 1993) deklarierte den protektiven Antitoxintiter für Menschen methodenspezifisch mit 0,1 IE/ml im ELISA. Inwieweit der aus eigenen Untersuchungen resultierende Cut off von 0,11 IE/ml tatsächlich protektiven Charakter besitzt, muss in weiteren Untersuchungen geklärt werden. Ursachen für die Differenz von 0,01 IE könnten speziesspezifisch begründet sein. Mögliche Probenausreißer oder Effekte könnten in der Humanmedizin durch Patientenbefragungen anamnestisch konkreter charakterisiert worden sein.

Während der Cut off einen distinkten Unterscheidungswert darstellt, beschreibt der sogenannte Schwellenwert den medizinisch und/oder methodisch bedingten Unsicherheitsbereich in der Ergebnisinterpretation eines Verfahrens. Der Schwellenwert oder auch grenzwertiger Bereich bzw. Grauzone umfasst den Überschneidungs- bzw. Unterscheidungsbereich zwischen negativem und positivem Kollektiv (Anonymb, 2000). Der Schwellenwert wurde durch Addition des arithmetischen Mittelwertes der Antitoxingehalte nicht grundimmunisierter Jährlingsstuten mit deren einfacher Standardabweichung errechnet. Der für dieses Verfahren ermittelte Schwellenwert betrug 0,072 IE/ml. Bei einem angenommenen Cut off von 0,11 IE/ml bedeutete dies: Proben $<0,072 \mathrm{IE} / \mathrm{ml}$ wurden als negativ ausgewertet. Antitoxingehalte von 0,072 IE/ml-0,11 IE/ml wurden als zweifelhaft eingeordnet. Antitoxingehalte $>0,11 \mathrm{IE} / \mathrm{ml}$ wurden als positiv gewertet.

Die Spezifität im ELISA ist die Fähigkeit des Antikörper ausschließlich das gesuchte Antigen sicher zu binden. Mit diesem Test sollte sichergestellt werden, dass keine falsch positiven Ergebnisse auftreten. Auf Grund des hohen Homologiegrades des Tetanustoxins zum Botulinumtoxin kam der Überprüfung eventuell auftretender Kreuzreaktionen mit diesen Toxintypen besondere Bedeutung zu (Schiavo et al., 2000). Die Versuche konnten belegen, dass keine Interferenzen bzw. keine Kreuzreaktionen mit $C$. botulinum-Toxinen auftraten. Die Sensitivität ist ebenfalls eine methodenspezifische Größe. Sie beschreibt die Fähigkeit des Testes, alle Pferdeseren mit hohen Tetanustitern sicher zu bestimmen. Die Untersuchung wurde an einer Herde von 30 Fohlen führenden tragenden Altstuten durchgeführt. Nach gestütsinternem Impfregime wurde eine Grundimmunisierung (zwei Impfungen im Abstand von vier Wochen) im Fohlenalter durchgeführt. Darauf folgten jährliche Boosterungen im Frühjahr vor dem Weideauftrieb mit Tetanus-Influenza-Kombinationsimpfstoff. Die letzte Vakzinierung vor Untersuchungsbeginn lag vier Monate zurück. Die Sensitivität für diesen ELISA wurde mit 89,7 \% angegeben. 8,7 \% (13 Tiere) der untersuchten Seren hatten Titer im grenzwertigen Bereich. Zwei Stuten (1,3 \%) wurden als seronegativ bestimmt. Die Differenz 
des theoretisch möglichen Wertes von 100 \% zum tatsächlichen Wert von 89,7 \% könnte verschiedene Ursachen haben: Vitamin A-Mangel (Molrine et al., 1995), Helminthenbefall (Cooper et al., 1999), Infektionserkrankungen, Immundefekte, verminderte Ansprechbarkeit des Immunsystems bei Kombinationsimpfstoffen oder Stress zum Zeitpunkt der Vakzinierung durch Ver- und Umladen, Reisen, Leistungsschauen, etc. Möglicherweise kann der Test niedrigtitrigere Antitoxingehalte um 0,1 IE/ml nicht zuverlässig bestimmen. Die Methodenvalidierung anhand der Referenzmethode sollte daher ebenfalls eine Aufgabe für zukünftige Arbeiten sein.

Tab. 8 gibt einen Überblick über ausgesuchte Validierungsparameter im Pferdetetanustest und zwei Humantesten. Neben dem bereits beschriebenen Cut off, der Einsatzmöglichkeit verschiedener Gerinnungshemmer bzw. Serum und dem Einfluss der Probenverdünnung werden auch der Intraassayvarianzkoeffizient sowie der Interassayvarianzkoeffizient angegeben. Der Intraassayvariationskoeffizient beschreibt die durchschnittliche Abweichung aller Werte ausgehend von ihrem geometrischen Mittelwert einer Probe in einem Testdurchlauf. Der Interassayvariationskoeffizient gibt die Abweichung aller Werte einer Standardzubereitung zum geometrischen Mittelwert in mehreren Testdurchläufen an. Die Bestimmung beider Parameter dient der Bestätigung der Präzision und Richtigkeit einer Methode.

\begin{tabular}{|c|c|c|c|}
\hline Parameter & Eigener Test & Anonym $_{c}(2003)$ & Anonym $_{d}(2003)$ \\
\hline Cut off & $0,11 \mathrm{IE} / \mathrm{ml}$ & $0,1 \mathrm{IE} / \mathrm{ml}$ & $0,1 \mathrm{IE} / \mathrm{ml}$ \\
\hline Intraassay-Varianz & $4,6 \%$ & $6,9 \%$ & $<12 \%$ \\
\hline Interassay-Varianz & $11,01 \%$ & $10,4 \%$ & $<10-26 \%$ \\
\hline $\begin{array}{l}\text { Verwendbarkeit von } \\
\text { Serum- bzw. Plasma }\end{array}$ & $\begin{array}{c}\text { Serum, EDTA-, } \\
\text { Heparin-, } \\
\text { Zitratplasma geeignet }\end{array}$ & $\begin{array}{l}\text { Serum, EDTA- und } \\
\text { Heparinplasma } \\
\text { geeignet }\end{array}$ & $\begin{array}{c}\text { Serum, EDTA-, } \\
\text { Heparin-, } \\
\text { Zitratplasma geeignet }\end{array}$ \\
\hline Probenverdünnung & $1: 100$ & $1: 100$ & $1: 100$ \\
\hline
\end{tabular}

Tab. 8: Vergleich von Validierungsparametern des eigenen Tests mit kommerziellen Anbietern

Die Intraassay-Varianz im Pferdetest ist mit 4,6 \% am niedrigsten und liegt damit unter dem Referenzbereich von 5 \% (OIE, 2004)). Die Interassayvarianz ist im Pferdetest geringfügig höher als im Humantest von Anonym ${ }_{c}$ und liegt im unteren Bereich von Anonym ${ }_{d}$. Die OIE 
(2000) gibt an, dass ein Interassayvariationskoeffizient $<20$ \% für eine angemessene Wiederholbarkeit des diagnostischen Verfahrens spricht.

Der entwickelte ELISA stellt ein geeignetes Verfahren dar, um tetanusspezifisches IgG im Pferdeserum zu bestimmen. Der Cut off betrug 0,11 IE/ml. Der Wert lag geringfügig über den ELISA-Grenzwerten in Humantesten von 0,1 IE/ml (WHO, 1993). Die Richtigkeit des Testes wurde am Kontrollserum festgelegt. Das Referenzserum wurde auf eine Konzentration von 10 IE/ml eingestellt. Die Intraassayvarianz des Kontrollserums ergab Werte < $\%$. Die Interassayvarianz des Pferde-ELISA war mit kommerziellen humanmedizinischen Produkten vergleichbar und lag unter der OIE-Richtlinie (2004) von 20 \%. Die Spezifität des Verfahrens wurde mittels C. botulinum-Toxinen belegt. Die Methodensensitivität betrug 89,7 \%, das heißt tetanusspezifische Titer wurden in 89,7 \% der untersuchten Seren von vollimmunisierten Stuten gefunden. Die Verwendung von Plasmaproben ist möglich. Auf Grund der Ergebnisvergleichbarkeit sollte der Test jedoch immer mit einer Probenmatrix durchgeführt werden. Versuche haben gezeigt, dass die Proben hundertfach vorverdünnt werden müssen.

Bei weitergehenden Untersuchungen sollten methodenspezifische Werte wie Cut off, Schwellenwert, Spezifität und Sensitivität an weiteren Pferdepopulationen bestätigt werden. Da es sich bei den in dieser Arbeit untersuchten Tieren ausschließlich um Haflinger handelte, sollten mögliche rassespezifische Einflüsse ausgeschlossen werden. Weiterer Klärungsbedarf besteht in der Untersuchung des Einflusses bestehender akuter und chronischer Erkrankungen, sowie Interferenzen mit Pharmaka während der Immunisierungsperiode. Zur Bestimmung der Korrelation mit der Referenzmethode sollten die Ergebnisse im in vivo-Maus-/Meerschweinchentest abgeglichen werden.

\subsubsection{Milch-ELISA}

Ziel dieses Testes war die Verfolgbarkeit des maternalen Antitoxingehaltes (IgG) in Kolostrum und Milch. Das Kolostrum stellt für das Fohlen die einzige Immunglobulinquelle dar (Tizard, 2004). Aus diesem Grund schien es bedeutsam zu überprüfen, inwieweit sich der tetanusspezifische IgG-Gehalt während der frühen Laktation verändert und wie sich vergleichend dazu der Antitoxingehalt im Fohlenserum verhält. 
Der Verfahrensaufbau und Ablauf wurde vom Serum-ELISA adaptiert. Milch und Kolostrum stellte eine andere Probenmatrix als Serum dar. Die Verfahrensanweisung zur Aufarbeitung von Milchproben wurde von WINTEROFF (2000) übernommen. Zweck der Reninbehandlung war die Trennung der lipophilen von der wässrigen Phase der Milch. Der Fettgehalt der Milch könnte sich einerseits störend auf die Testdurchführung auswirken. Andererseits führt eine interne Probentrübung zu einer unkontrollierten Lichtabsorption und Lichtstreuung während des Messvorganges. Die Dicklegung der Milch erfolgte bei $37^{\circ} \mathrm{C}$ im Wasserbad. Die Gerinnungszeiten der Milch- und Kolostrumproben schwankten zwischen 45 min und drei Stunden Ursache dafür könnten unterschiedliche Konzentrationen der verschiedenen Milchinhaltsstoffe während der frühen und späten Laktation sein. Parameter, die sich innerhalb der Laktationsperiode verändern, sind der Gesamtprotein-, Fett- und der Laktosegehalt (Seifert und Böhnel, 1995).

Im Gegensatz zu reifer Milch liegt in Kolostrum ein Überschuss an IgG zu IgA im Verhältnis von 34:1 vor (McGuire und Crawford, 1972). In der fortschreitenden Laktation verändert sich das Verhältnis zu Gunsten des IgA. IgA ist das vorherrschende Immunglobulin der Körperflüssigkeiten und Schleimhäute. Es kleidet die Körperoberflächen aus und verhindert die Invasion pathogener Mikroorganismen (Marcotte und Lavoie, 1998). Die kontinuierliche Aufnahme IgA-reicher Milch durch das Fohlen ist möglicherweise die Ursache der geringen Tetanuserkrankungshäufigkeit im Saugfohlenalter.

\subsubsection{Korrelation zwischen Serum- und Milch-ELISA}

Eine Korrelation des Milchtiters zum Tetanusantitoxingehalt im Serum der Mütter vor und nach Boosterung war nicht gegeben. Die Ergebnisse des Serum-ELISA korrelieren nicht mit dem Milch-ELISA. Eine Überprüfung des Impfstatuss’ oder ein Vakzinierungsmonitoring kann deshalb nur mittels Blut-/Serum-ELISA durchgeführt werden. Der Milch-ELISA lässt keine Aussage über den Impftiter zu. Der Gehalt an Tetanusantitoxin korrelierte mit dem Laktationsstadium. Innerhalb der ersten 7-14 Laktationstage sank der Milchtiter unter den Cut off. 


\section{$5 \quad$ Felduntersuchungen}

Im Rahmen der Dissertation war es möglich, das Verfahren umgehend praktisch zu erproben.

\subsection{Materialien und Methoden}

\subsubsection{Untersuchungsgruppen}

Zur Erstellung der vorliegenden Arbeit wurden fünf Untersuchungsgruppen aufgestellt.

1. Gruppe: 30 tragende Fohlen führende Stuten in ganztägiger Weidehaltung; Beprobungszeitraum August bis November 2004

2. Gruppe: 11 hochtragende Stuten in Stallhaltung; Beprobungszeitraum Januar bis Juni 2005; Der Beobachtungszeitraum umfasste die letzten Wochen a. p. bis 100 Tage p. p.

3. Gruppe: 11 Saugfohlen der Stuten aus Gruppe 2; Beprobung Januar bis September 2005

4. 10 Jungstuten in Stallhaltung (geboren im Winter/Frühjahr 2004; Beprobungszeitraum Januar bis April 2005

5. Fallbeispiel der Großtierklinik des fzmb

\subsubsection{Bestimmung und Verlauf des maternalen Schutzes im Serum neugeborener Fohlen}

Zur Bestimmung und Verlaufskontrolle des passiven maternalen tetanusspezifischen Antikörpergehaltes wurde Serum von 11 neugeborenen Fohlen und ihrer Mütter über einen Zeitraum von sechs Monaten p. p. untersucht. Die Probenahmen erfolgten im Abstand von 21-30 Tagen.

Alle Fohlen kamen gesund und voll entwickelt zur Welt. Es handelte sich um sechs weibliche und 5 männliche Tiere. Die tierärztliche Beobachtung der Fohlen über den Untersuchungszeitraum ergab keine Anhaltspunkte für eine Erkrankung oder Entwicklungsstörung. Die Aufnahme von Kolostrum und Milch erfolgte selbstständig nach individuellem Bedarf. Alle Fohlen wurden im Rahmen des betrieblichen Impfplanes entwurmt (Paramectin $\left.{ }^{\circledR}\right)$. 


\subsubsection{Titerverlauf bei einjährigen Jungstuten vor und nach Tetanusgrundimmunisierung}

In dieser Studie wurden 10 Jungstuten berücksichtigt. Das Alter der untersuchten Tiere betrug zu Versuchsbeginn durchschnittlich 10-12 Monate. Die Jungstuten wurden am 90. Tag nach Untersuchungsbeginn erstmalig mit divalentem Tetanus-Influenza-Impfstoff grundimmunisiert. Die zweite Grundimmunisierung erfolgte 30 Tage nach der Erstvakzinierung. Der Titerverlauf nach der zweiten Grundimmunisierung konnte aus logistischen Gründen im Gestüt nur innerhalb der folgenden sechs Tage verfolgt werden. Die Probenahme erfolgte vor der Grundimmunisierung alle 21 bis 30 Tage. Die erste Probe nach der ersten Vakzinierung wurde nach zwei Tagen gewonnen. Danach erfolgte die Beprobung im Abstand von fünf bis neun Tagen. Aus betriebswirtschaftlichen und tierärztlichen Gründen wurde auf die Mitführung einer nichtimmunisierten Vergleichsgruppe verzichtet. Alle Tiere wurden im Rahmen des betrieblichen Impfplanes entwurmt (Paramectin ${ }^{\circledR}$ ).

\subsubsection{Titerverlauf bei Saugfohlen nach Tetanusgrundimmunisierung}

In dieser Untersuchungsgruppe wurden die bereits in Kapitel 5.3.1 beschriebenen Fohlen untersucht. Die Untersuchungsgruppe umfasste 11 Fohlen im Alter von drei bis vier Monaten. Sie wurde in zwei Teilgruppen mit fünf bzw. sechs Tieren unterteilt. Die erste Gruppe wurde nicht tetanusgeimpft. Die Tiere der zweiten Untersuchungsgruppe erhielten je nach Geburtstermin 130-150 Tage p. p. intramuskulär eine initiale Dosis Tetanustoxoidimpfstoff. Die zweite Grundimmunisierung erfolgte ebenfalls mit monovalentem Toxoidimpfstoff intramuskulär 33 Tage nach der Erstimmunisierung. Während des gesamten Untersuchungszeitraumes verblieben die Fohlen beider Teilgruppen bei ihren Müttern und wurden gesäugt.

Die Probenahmen wurden nach zwei Tagen, danach alle fünf bis neun Tage durchgeführt. Aus logistischen Gründen erfolgte die Haltung der Fohlen mit ihren Müttern während des Untersuchungszeitraumes in Laufställen mit stundenweisem Weidegang auf gestütsnahen Flächen. 


\subsubsection{Titerverlauf immunisierter Altstuten nach Boosterung}

In dieser Studie wurden zu Beginn 15 hochtragende Stuten berücksichtigt, deren vermutete Abfohltermine saisonal zeitig und eng beieinander lagen. Die ersten 11 abfohlenden Tiere wurden p. p. weiterverfolgt. In die Untersuchungsergebnisse flossen lediglich die Titer der letztendlich p. p. untersuchten Stuten ein. Die letzte Boosterung der Stuten vor Untersuchungsbeginn lag acht Monate zurück.

Die Probenahmen vor der Impfung erfolgten im Abstand von 21 bis 30 Tagen. Nach der Immunisierung erfolgte die Probenahme in den ersten vier Wochen alle fünf bis neun Tage, später alle 21-30 d.

\subsubsection{Verlauf des tetanusspezifischen IgG-Gehaltes in Kolostrum/Milch}

Die Studie zur Bestimmung des tetanusspezifischen Antikörpergehaltes in Kolostrum und reifer Milch beinhaltete 11 frisch laktierende Stuten. Die Probenahmen erfolgten wöchentlich am 0.,7., 14., 21., 28. bis 70. Tag p. p. Alle Fohlen wurden lebend und komplikationslos geboren. Es traten in keinem Fall Puerperalstörungen auf. Die Haltung der Stuten und ihrer Fohlen erfolgte während des Untersuchungszeitraumes in Laufställen bzw. stundenweise auf nahegelegenen Koppeln. Die Mutterstuten wurden nach dem betriebsinternen Impfmodus im April jeden Kalenderjahres vor dem Weideaustrieb immunisiert. Vor der Verabreichung der Impfungen wurden die Stuten entwurmt $\left(\right.$ Paramectin $\left.^{\circledR}\right)$.

\subsubsection{Titerverlaufkontrolle eines an Tetanus erkrankten Fohlen}

Tara wurde mit typischen klinischen Anzeichen eines generalisierten Tetanus' in der Tierklinik des fzmb vorstellig: steifer Gang, hohes Fieber, Lidvorfall, Speicheln, seitlich abgestellter Schweif. Das Tier machte einen offensichtlich schwerkranken Eindruck. Es handelte sich um ein vier Monate altes weibliches Haflingerfohlen. In der Anamnese wurde ein zumindest unvollständiges Impfregime bei der Stute durch den Besitzer bestätigt. Das Fohlen wurde nicht grundimmunisiert. Eine offensichtliche Primärläsion beim Fohlen war nicht festzustellen. Auf Grund der Anamnese und Symptomatik wurde die Diagnose Tetanus 
gestellt. Beim Fohlen wurden umgehend Serumproben gewonnen. Die Stute erhielt eine Dosis Tetanustoxoidimpfstoff (Equilis ${ }^{\circledR}$, Intervet, Oberschleißheim). Das Fohlen wurde mit Hyperimmunglobulin (WDT) intravenös und intramuskulär behandelt. Zusätzlich wurden umgehend intensivmedizinische Maßnahmen eingeleitet. Zur Kontrolle des Antitoxintiters wurde dem Fohlen während des Klinikaufenthaltes wiederholt Blut entnommen und untersucht. Es konnte nach zwei Wochen aus der Klinik entlassen werden. 


\subsection{Ergebnisse}

5.2.1 Verlauf des maternalen tetanusspezifischen IgG-Gehaltes im Serum neugeborener Fohlen

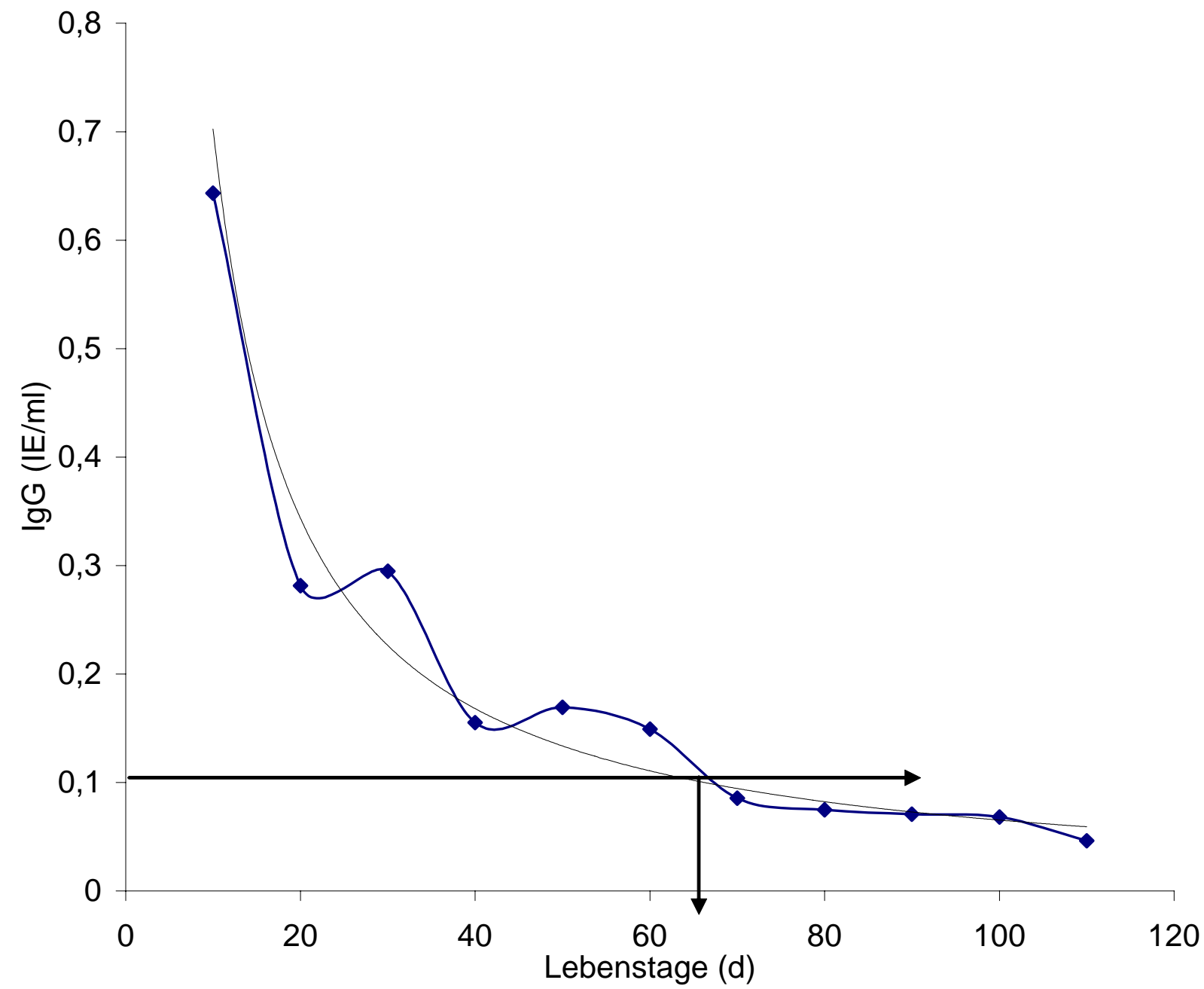

Abb. 6: Verlauf des maternalen anti-Tetanus-IgG-Gehalt im Serum neugeborener Fohlen

Abb. 6 stellt den Verlauf des tetanusspezifischen IgG-Gehaltes in Fohlenseren dar. Für die Erstellung der Titerverlaufskurve wurden die Fohlen in Gruppen (0-10 Tage, 11-20 Tage bis 100-110 d) aufgeteilt. Der arithmetische Mittelwert der Gruppentiter wurde gegen die Lebenstage aufgetragen. Die Titerverlaufskurve folgt einer exponentiellen Funktion (schwarze Kurve). Konkret sank der tetanusspezifische IgG-Gehalt innerhalb der ersten 20 Lebenstage von durchschnittlich 0,64 IE/ml auf durchschnittlich 0,28 IE/ml. Zwischen dem 20. und 30. Lebenstag stagniert der Wert um 0,3 IE/ml. Nach dem 30. Tag sank der 
Tetanustiter auf Werte um 0,16 IE/ml. Diese blieben bis zum 60. Lebenstag annähernd konstant. Am 65. Lebenstag erreichte der mittlere Titer den Cut off von 0,11 IE/ml. Ab diesem Zeitpunkt wurden die Fohlen als seronegativ beschrieben. Nach dem 70. Lebenstag nahm der Tetanustiter weiter ab.

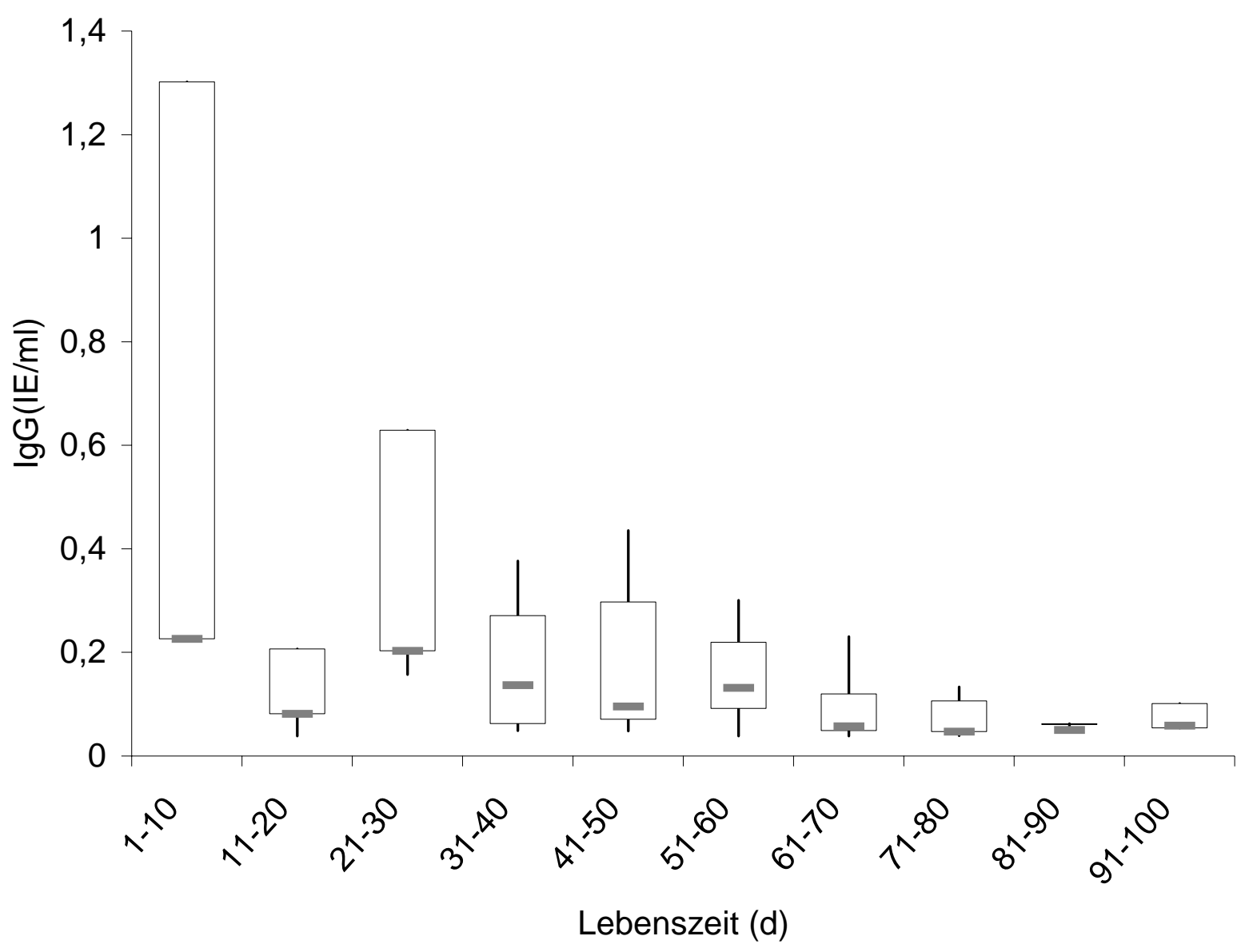

Abb. 7: Boxplot des maternalen Anti-Tetanus-IgG in Seren neugeborener Fohlen

Die Schwankungsbreiten der tetanusspezifischen Antitoxintiter waren in den ersten Lebenstagen groß und nahmen mit dem Lebensalter der Fohlen ab (Abb. 7).

\subsubsection{Titerverlauf bei einjährigen Jungstuten nach Tetanusgrundimmunisierung}

Abb. 8 zeigt den Titerverlauf bei nicht grundimmunisierten Jährlingen bis sechs Tage nach der ersten und zweiten Grundimmunisierung. Die Ausgangstiter lagen um 0,05 IE/ml. Die Antitoxingehalte entwickelten sich zögernd aber stetig, so dass ca. ab dem 10. Tag nach der initialen Impfung Tetanustiter von 0,5-2,5 IE/ml gemessen wurden. Dieser Effekt hielt bis 
zum 29. Tag, an dem die zweite Tetanusimpfung appliziert wurde. Die wiederholte Immunisierung resultierte in einem Anstieg der tetanusspezifischen Antikörper nach dem zweiten Tag. Sechs Tage nach der zweiten Grundimmunisierung hatten die Jungstuten durchschnittliche Titer von 11,21 IE/ml (4-21 IE/ml).

Abb. 9 veranschaulicht die Werteschwankungen bei Jungstuten vor und nach der initialen Vakzinierung. Der Grad der Immunantwort innerhalb der Untersuchungsgruppe scheint bis zum 31. Tag nach der Impfung annähernd gleichwertig. Es zeigten sich nur geringgradige interindividuelle Schwankungen. Die Schwankungsbreite des tetanusspezifischen Antikörpergehaltes der Einzelindividuen nahm nach dem 31. Tag mit der Höhe des Titers zu.

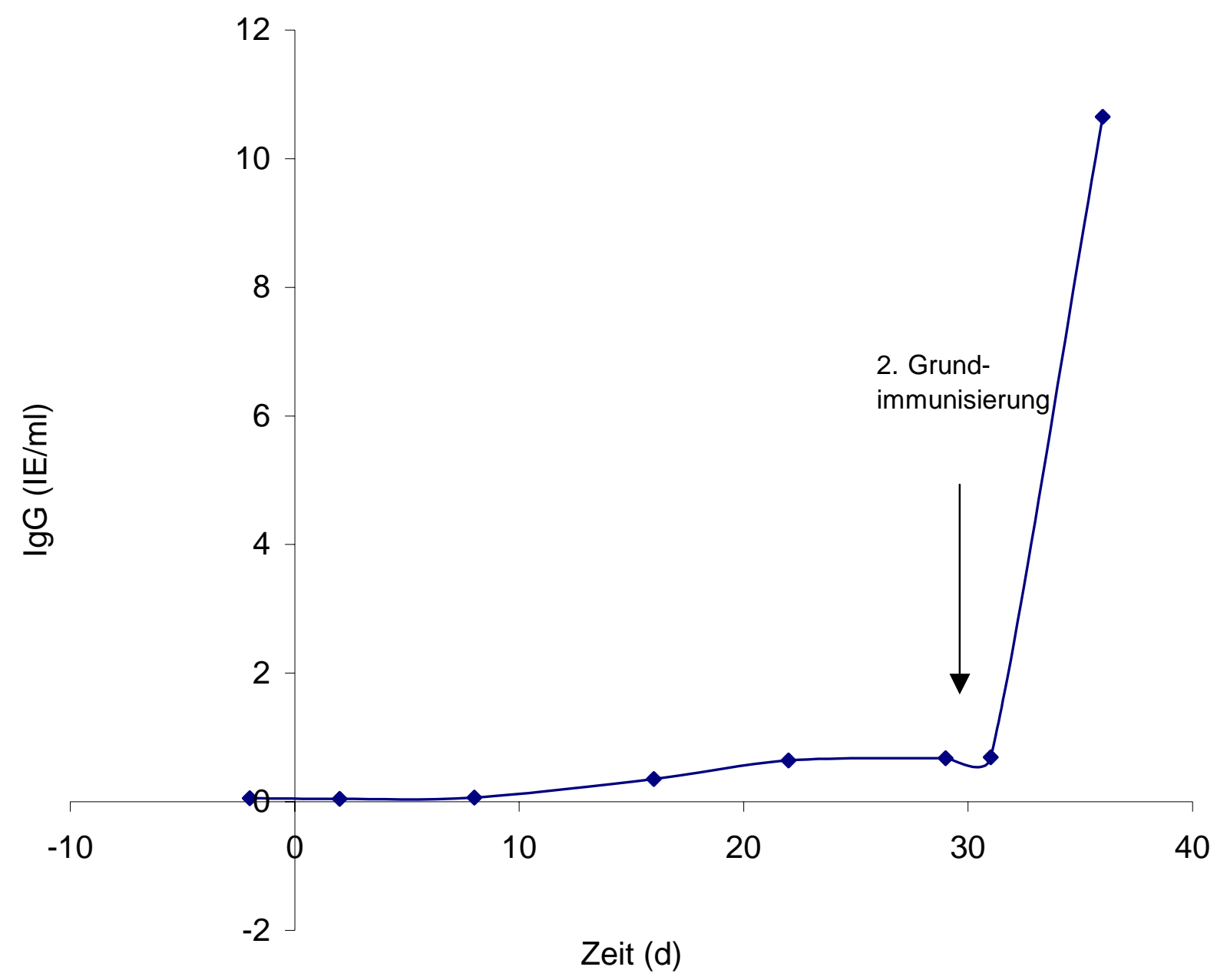

Abb. 8: Tetanus-Antitoxin-Titerverlauf bei Jungstuten nach Tetanusgrundimmunisierung 


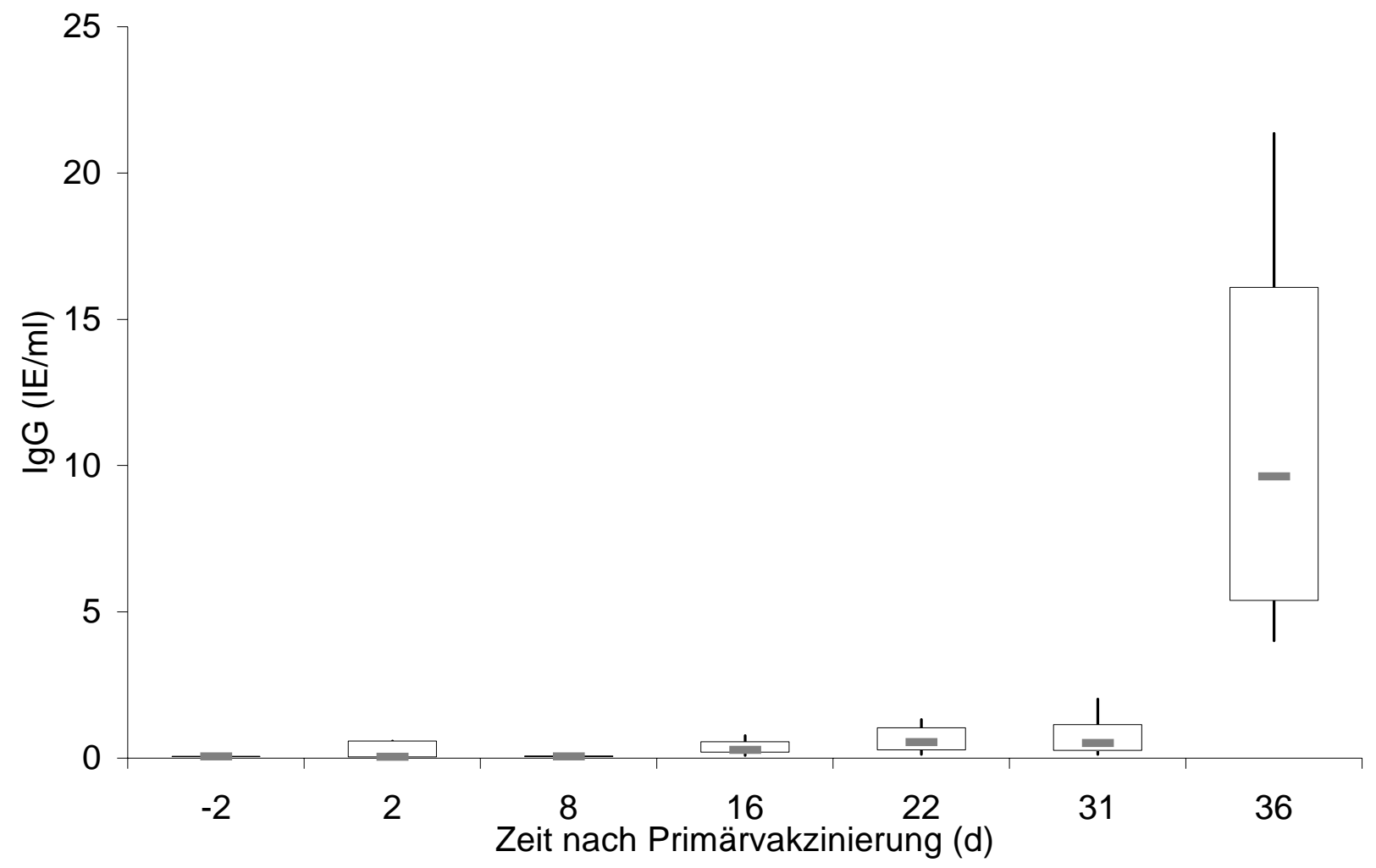

Abb. 9: Boxplot des tetanusspezifischen IgG-Gehaltes von Jungstuten nach Tetanusgrundimmunisierung

\subsubsection{Titerverlauf bei Saugfohlen nach vollständiger Grundimmunisierung}

Der Kurvenverlauf nach der Tetanusgrundimmunisierung bei Fohlen zeigt einen zweiphasigen Verlauf. Nach der initialen Impfung stieg der Titer langsam an. Die maximale Höhe erreichte der Serumtiter nach durchschnittlich 23 Tagen, um danach wieder abzufallen. Am 33. Tag (0,784 IE/ml) erfolgte die zweite Immunisierung. Diese induzierte einen unmittelbaren Anstieg der Antitoxintiter auf Werte von durchschnittlich 2,14 IE/ml am 37. Tag und folgend auf 8,374 IE/ml am 59. Tag (Abb. 10). 


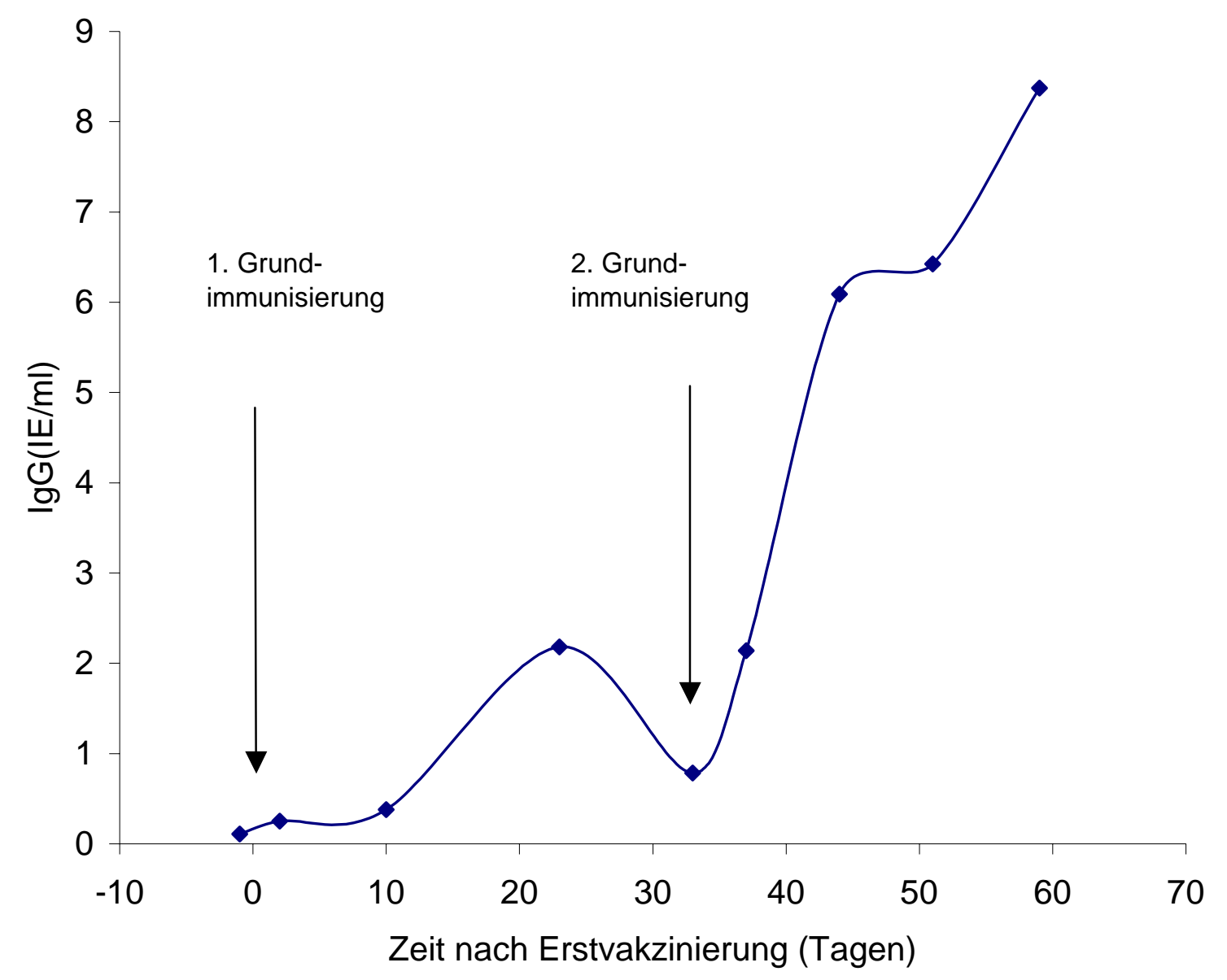

Abb. 10: Titerverlauf von tetanusspezifischem IgG im Serum von Saugfohlen nach erster und zweiter Tetanusgrundimmunisierung

Die individuellen Schwankungsbreiten der tetanusspezifischen Antikörpertiter zeigt Abb. 11. Die Schwankungsbreite der Antitoxintiter der Einzeltiere ist zu Beginn der Untersuchungen relativ gering. Sie stieg insbesondere nach Gabe der zweiten Dosis an.

Abb. 12 stellt die Serumtiterspiegel der geimpften im Vergleich zur ungeimpften Kontrollgruppe dar. Im Gegensatz zur nichtimmunisierten Kontrollgruppe besaßen die grundimmunisierten Saugfohlen nach der zweiten Immunisierung hohe tetanusspezifische Titer. 


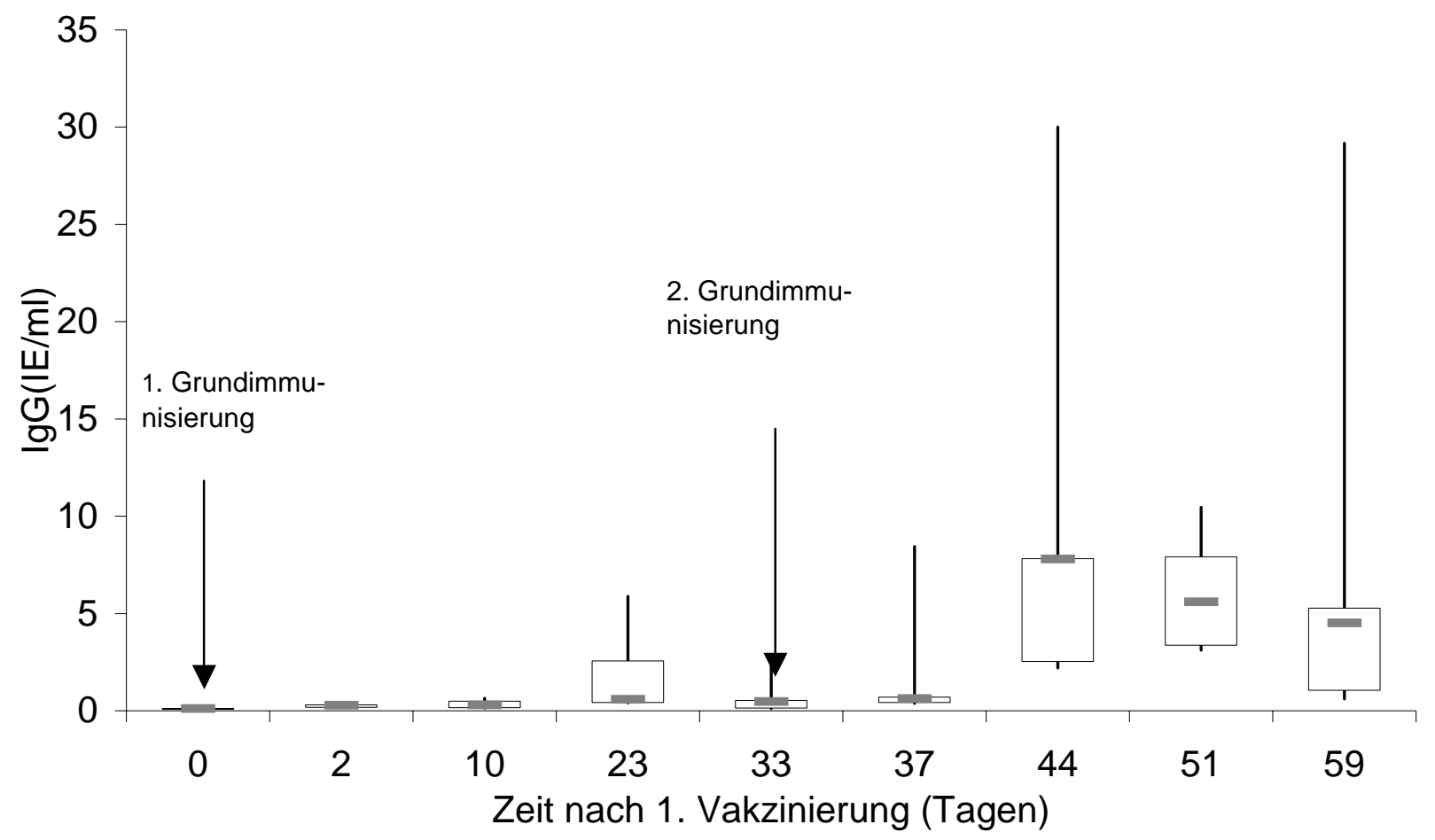

Abb. 11: Schwankungsbreite des Tetanus-IgG-Gehaltes in Seren grundimmunisierter Saugfohlen

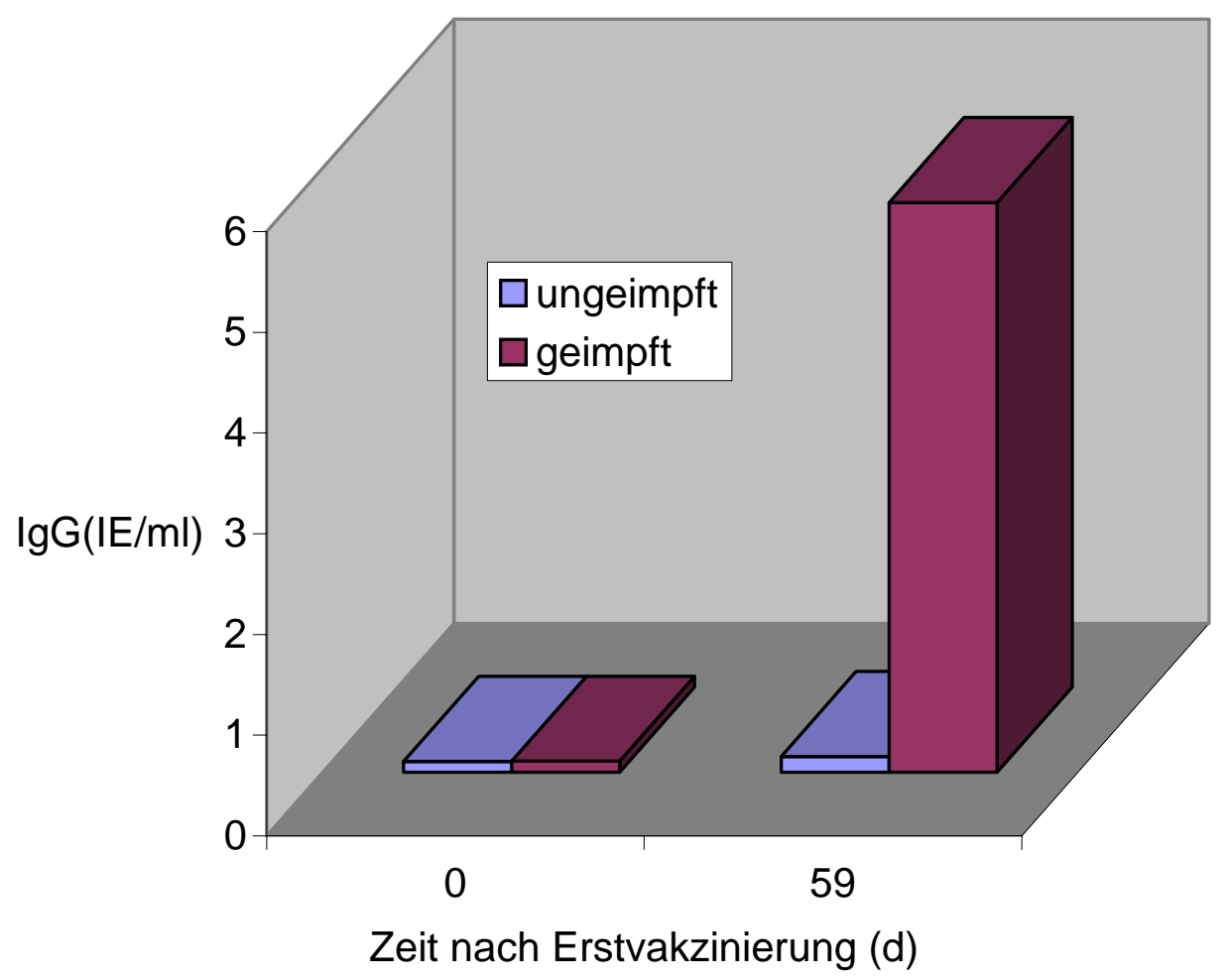

Abb. 12: Tetanus-Antitoxinspiegel im Serum grundimmunisierter und nicht grundimmunisierter Saugfohlen 


\subsubsection{Titerverlauf im Serum immunisierter Altstuten nach Boosterung}

Abb. 13 veranschaulicht den Antitoxinspiegel im Serum immunisierter Altstuten vor und nach der jährlichen Boosterung. Der Untersuchungsbeginn der Stuten korreliert dabei mit dem Ende der Trächtigkeit bzw. dem Beginn der postnatalen Phase. In den ersten Untersuchungstagen stieg der Antitoxingehalt kontinuierlich von durchschnittlich 0,625 IE/ml auf 1,07 IE/ml an. Bereits einen Tag nach Boosterung reagierten die Tiere mit einem Antikörperanstieg auf Werte von 1,54 IE/ml. Am 9. Tag nach der Boosterung erreichten die Stuten ihren Maximalwert von 13, 95 IE/ml. 29 Tage nach der Vakzinierung hatten die Tiere Werte in Größenordnungen von durchschnittlich 7,934 IE/ml.

Abb. 14 stellt die Streuung der Antitoxintiter über den Untersuchungszeitraum dar. Zu Beginn der Untersuchung hatten alle Tiere niedrige Ausgangstiter mit geringer Streuung, die jedoch deutlich über dem Cut off lagen. Mit Zunahme der Immunreaktion nach der Wiederholungsvakzinierung am 72. Tag stiegen sowohl Antitoxingehalt und die Streuung der Einzelwerte.

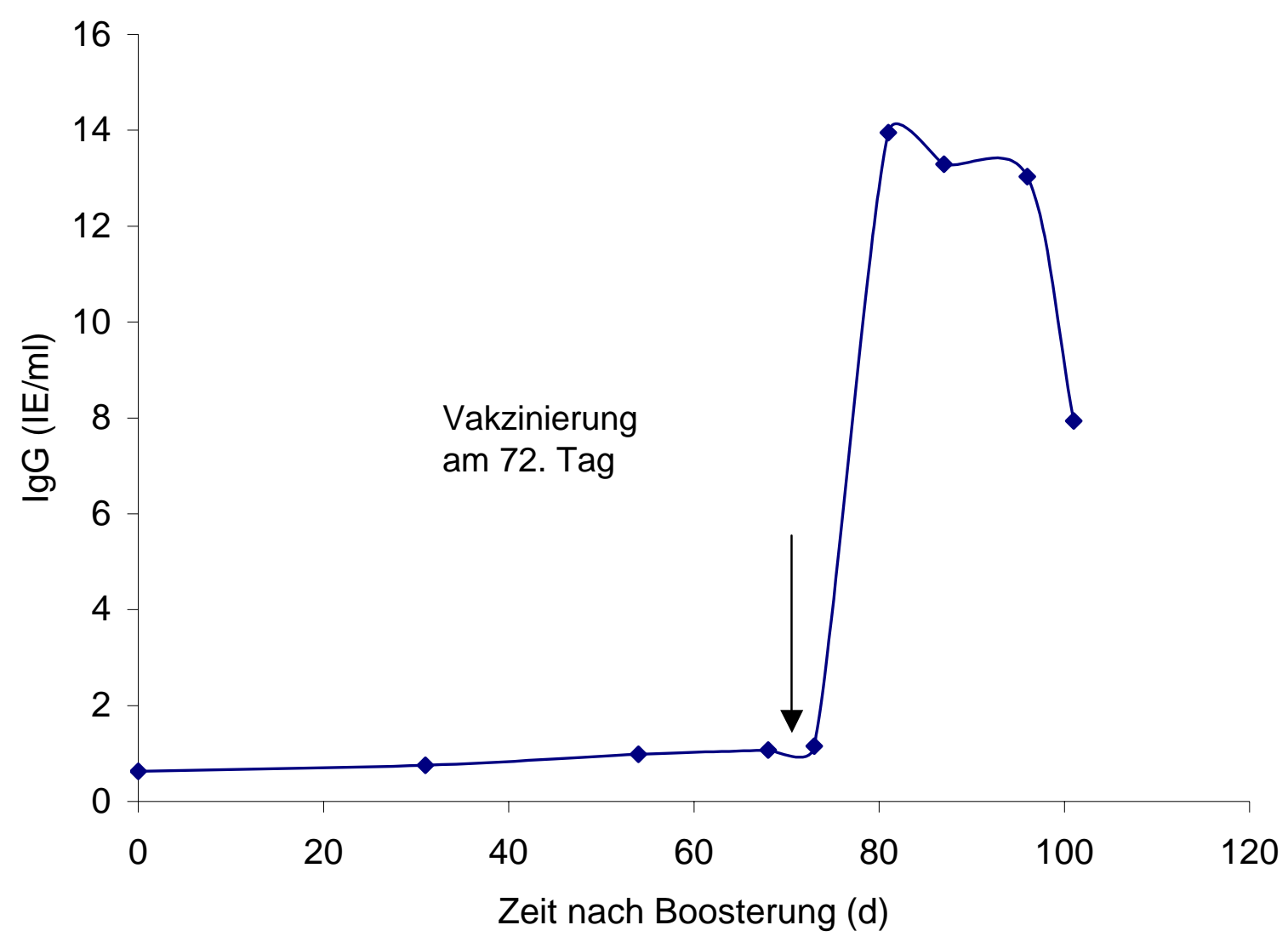

Abb. 13: Titerverlauf bei gut immunisierten Altstuten nach Boosterung 


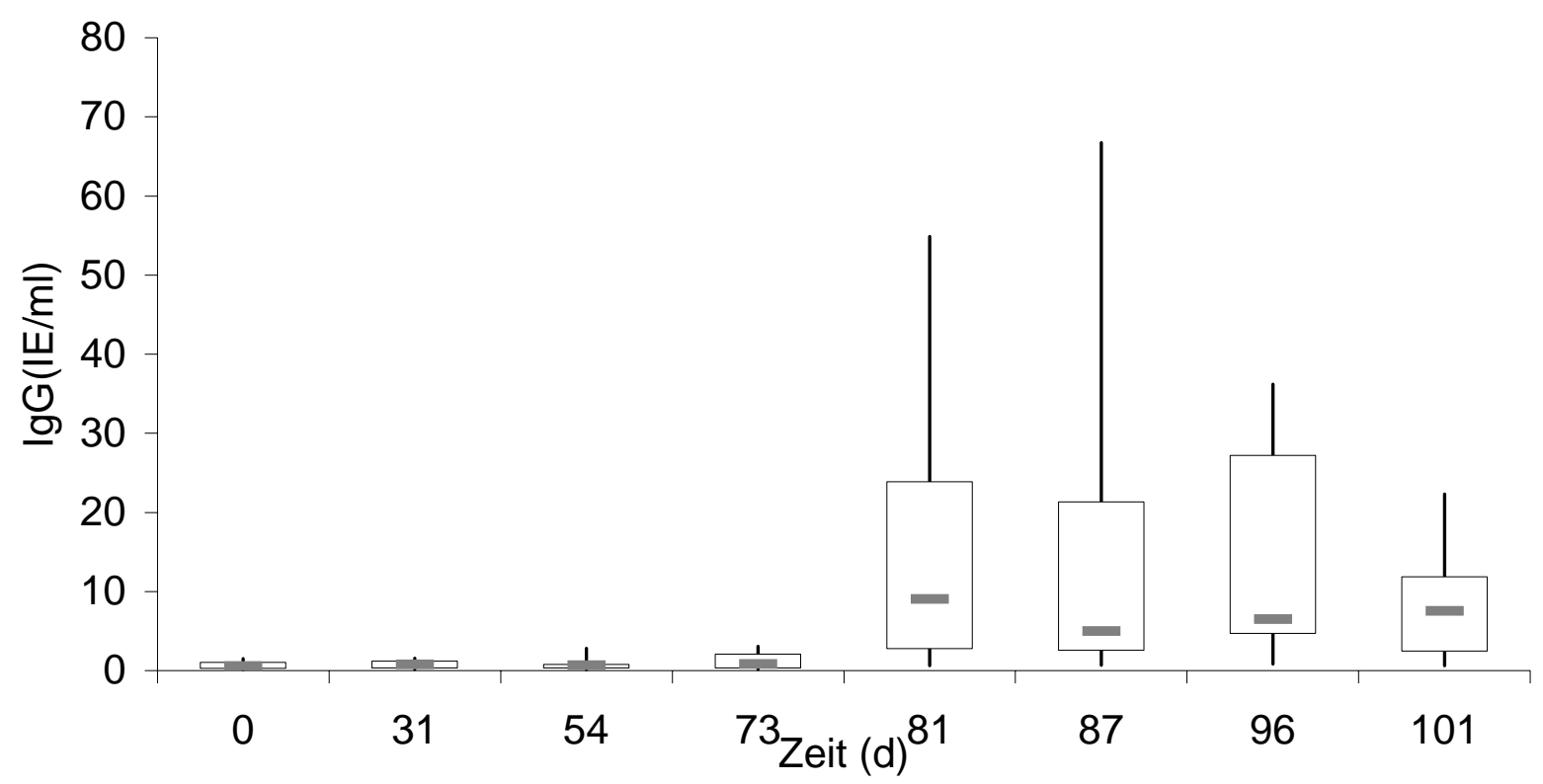

Abb. 14: Boxplot der tetanusspezifischen Antitoxintiter in Seren von gut immunisierten Altstuten nach Boosterung

5.2.5 Verlauf des tetanusspezifischen Antikörpergehaltes in Kolostrum und Milch

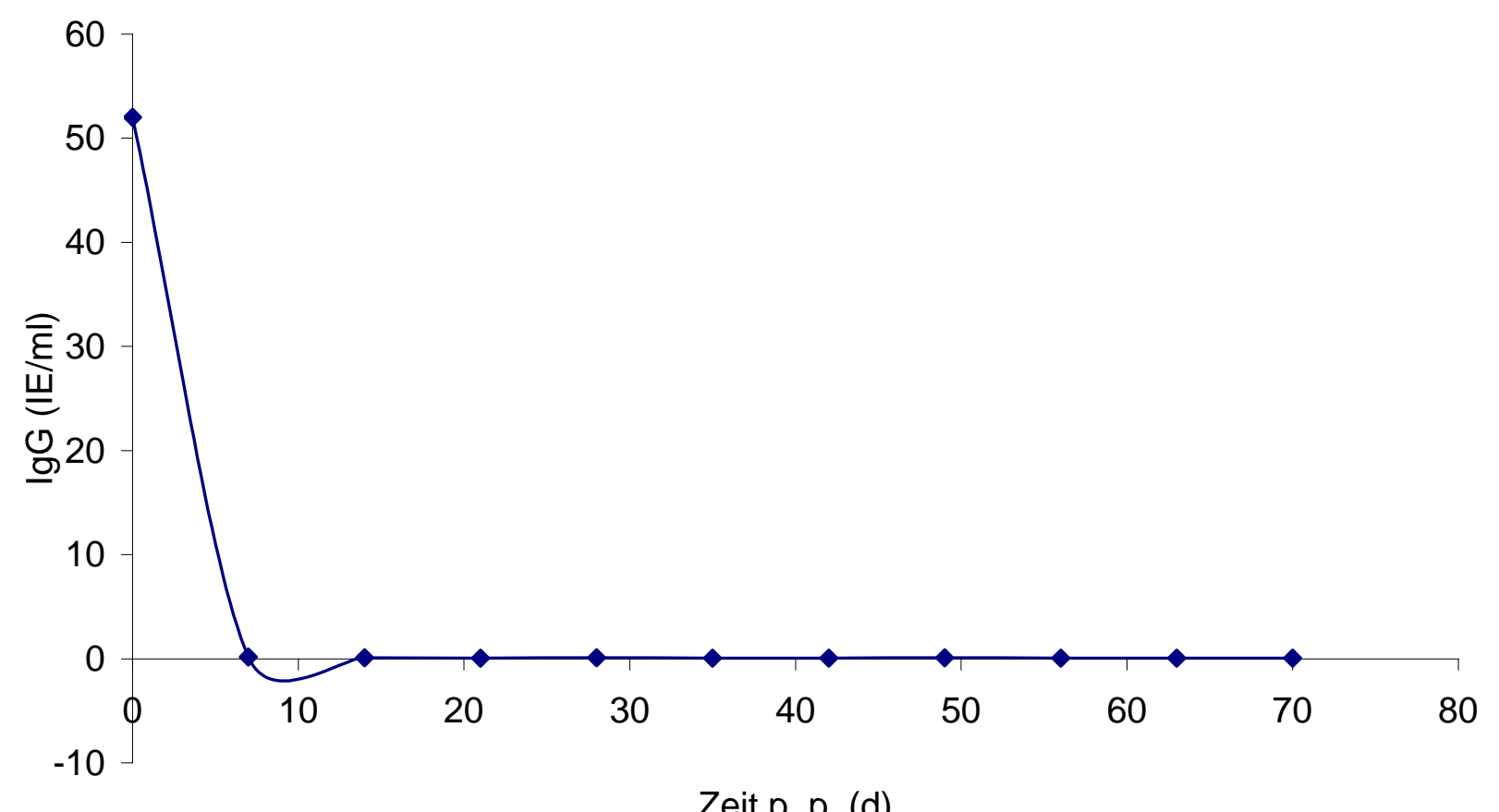

Abb. 15: Anti-Tetanus-IgG-Gehalt in Kolostrum und Milch 
Abb. 15 zeigt den Verlauf des tetanusspezifischen IgG-Gehaltes in Kolostrum und Milch vollimmunisierter Stuten nach der Geburt.

Der tetanusspezifische IgG-Gehalt in Stutenmilch sank innerhalb der ersten Lebenstage schnell und kontinuierlich ab. Bereits zwischen dem siebten und 14. Tag p. p. unterschreitet der IgG-Gehalt den Cut of-Wert von 0,11 IE/ml (7. Tag: 0,16112948 IE/ml; 14. Tag: $0,1006702 \mathrm{IE} / \mathrm{ml})$.

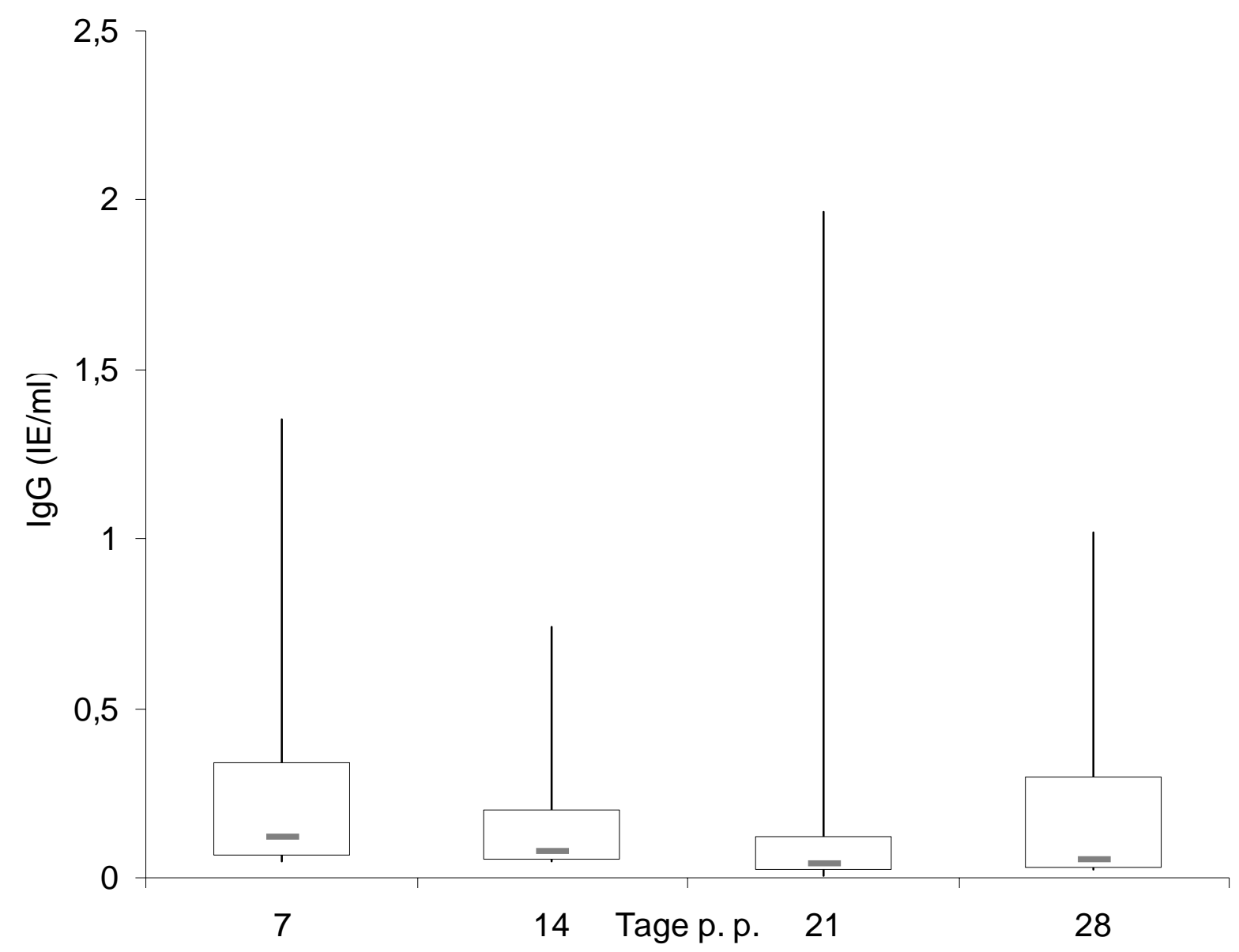

Abb. 16: Werteschwankungen des Anti-Tetanus-IgG-Gehaltes in Kolostrum und Milch

Die Schwankungsbreite des Antitoxintiters in Kolostrum und Milch über einen Zeitraum von sieben bis 28 Tagen nach der Geburt veranschaulicht Abb. 16. 
5.2.6 Vergleich der Tetanus-Antitoxin-IgG-Titer in Kolostrum/Milch und Stutenserum mit den Serumgehalten der Fohlen

Abb. 17 veranschaulicht die Titerverläufe in Kolostrum und Fohlenserum bis 70 Tage p. p. Innerhalb der ersten Tage nach der Geburt sinkt der tetanusspezifische Antikörpergehalt in Kolostrum von durchschnittlich 52,0 IE/ml auf 0,16 IE/ml. Nach weiteren sieben Tagen unterschreitet der IgG-Gehalt mit 0,10067 IE/ml den Cut off von 0,11 IE/ml. Innerhalb der folgenden 55 Tage schwankte der Antikörperspiegel geringfügig (0,10067 IE/ml am 14. Tag p. p. bis 0,006 IE/ml am 70. Tag p. p.). Die Serumspiegel der Fohlen sinken in den ersten 35 Lebenstagen von 0,64 IE/ml stetig bis auf einen durchschnittlichen Wert von 0,155 IE/ml am 35. Tag p. p. Während der nächsten 21 Tage folgte eine Plateauphase. Nach dem 56.

Lebenstag sank der IgG-Spiegel wiederum ab. Durchschnittlich am 60. Tag p. p. unterschritt der Tetanus-IgG-Spiegel in den Fohlenseren den Cut off von 0,11 IE/ml. Ab diesem Tag wurden die Fohlen als seronegativ beschrieben.

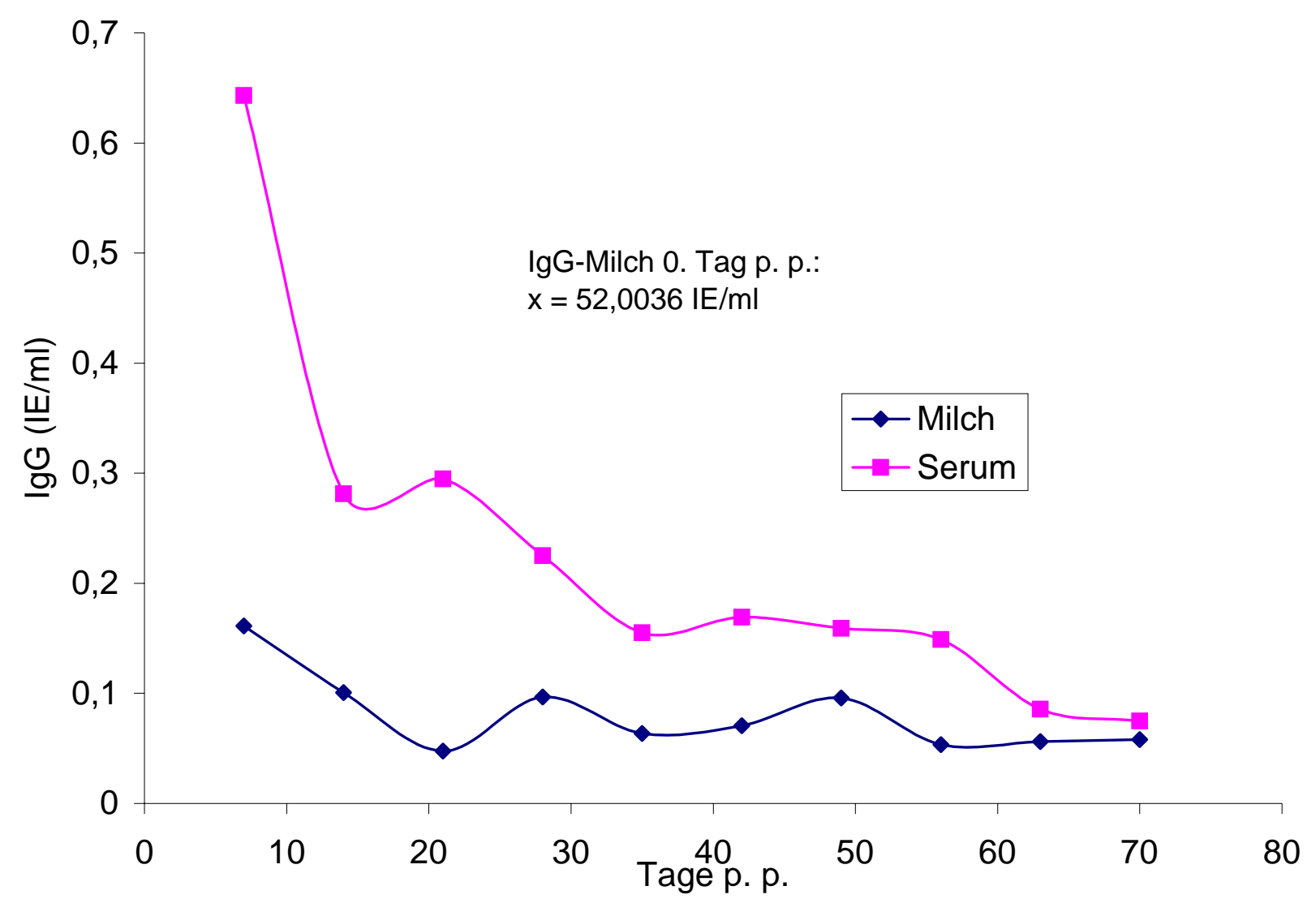

Abb. 17: Anti-Tetanus-IgG-Gehalt in Kolostrum/Milch und Fohlenserum 


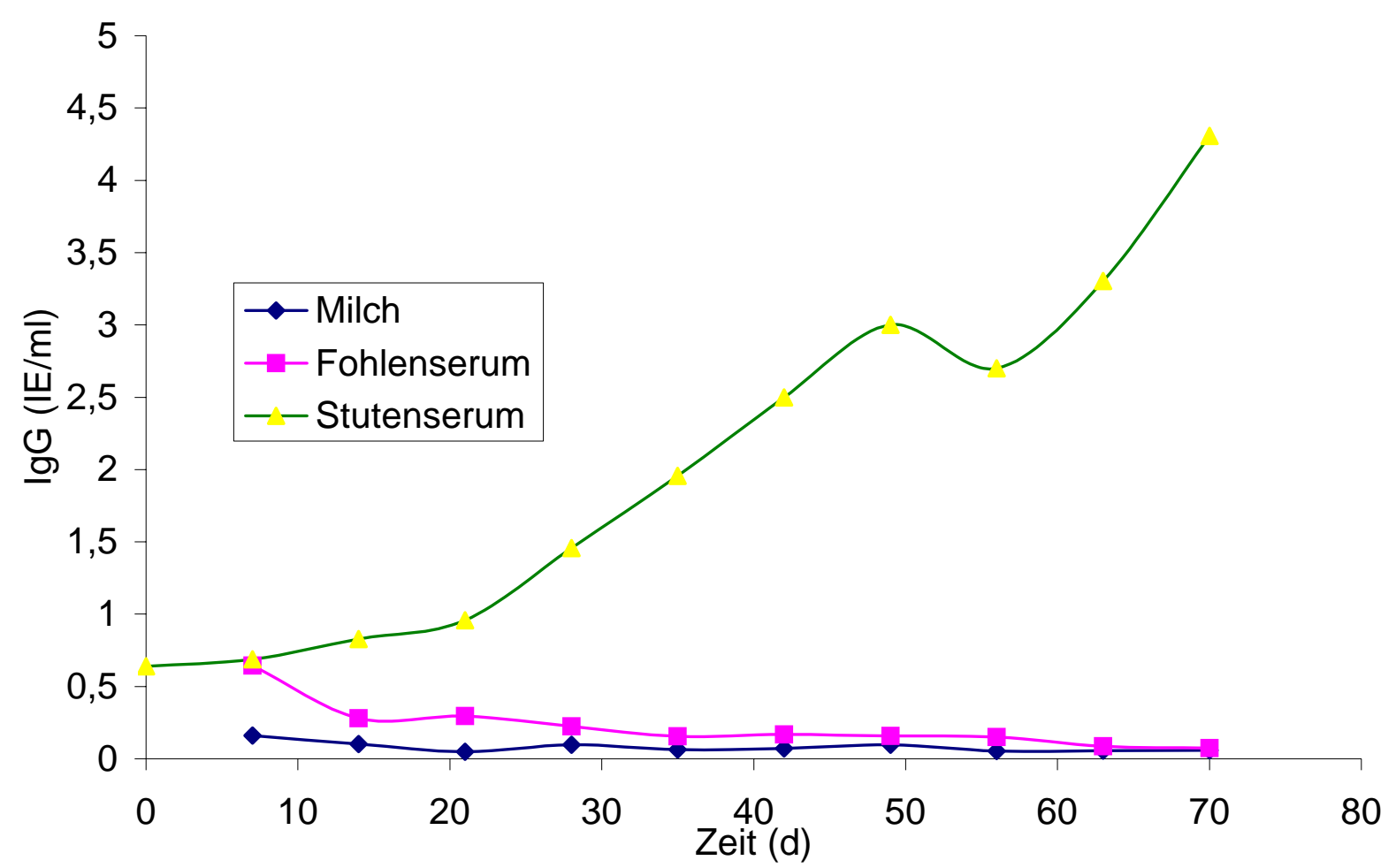

Abb. 18: Anti-Tetanus-IgG-Gehalt in Kolostrum/Milch, Stutenserum und Fohlenserum

Abb. 18 veranschaulicht die Titerverläufe in Kolostrum/Milch, Stutenserum und Fohlenserum. Am siebten Tag p. p. haben die Fohlenseren den gleichen Titer wie die Stutenseren. Nach dem siebten Tag kam es zu einem Anstieg der Stutentiter. Gleichzeitig sanken die Fohlentiter kontinuierlich ab. Am 62. Tag nach der Geburt sank der Antitoxingehalt der Fohlen unter den Cut off von 0,1 IE/ml. Die Fohlen besaßen zu diesem Zeitpunkt keinen maternalen Immunschutz mehr und wurden als seronegativ klassifiziert. Die Milchtiter sanken innerhalb der ersten Lebenstage von durchschnittlich 52 IE/ml am Tag der Geburt (im Diagramm nicht eingezeichnet) auf 0,161 IE/ml am 7. Tag p. p.. Am 14. Tag p. p. unterschritten die Milchtiter (0,1006 IE/ml) den Cut off. Nach dem 14. Tag schwankten die Antitoxingehalte der Milch geringfügig, überschritten jedoch zu keinem Zeitpunkt den Cut off. 


\subsubsection{Titerverlauf bei einem an Tetanus erkrankten Fohlen}

Der Serumtiter des Fohlens vor Behandlungsbeginn war 0,108 IE/ml. Der Wert lag knapp unter dem Cut off von 0,11 IE/ml. Mit Beginn der Serumtherapie (intravenös, intramuskulär) stieg der Antitoxintiter innerhalb eines Tages auf 0,196 IE/ml an. Die Gabe von Hyperimmunglobulin wurde an den folgenden Tagen fortgesetzt. Am vierten Tag nach Behandlungsbeginn erreichte der Titer einen Wert von 0,702 IE/ml. Mit fortschreitender Serumgabe und intensivmedizinischer Therapie verbesserte sich der Zustand des Tieres langsam und kontinuierlich. Zwei Wochen nach Behandlungsbeginn konnte das Tier entlassen werden.

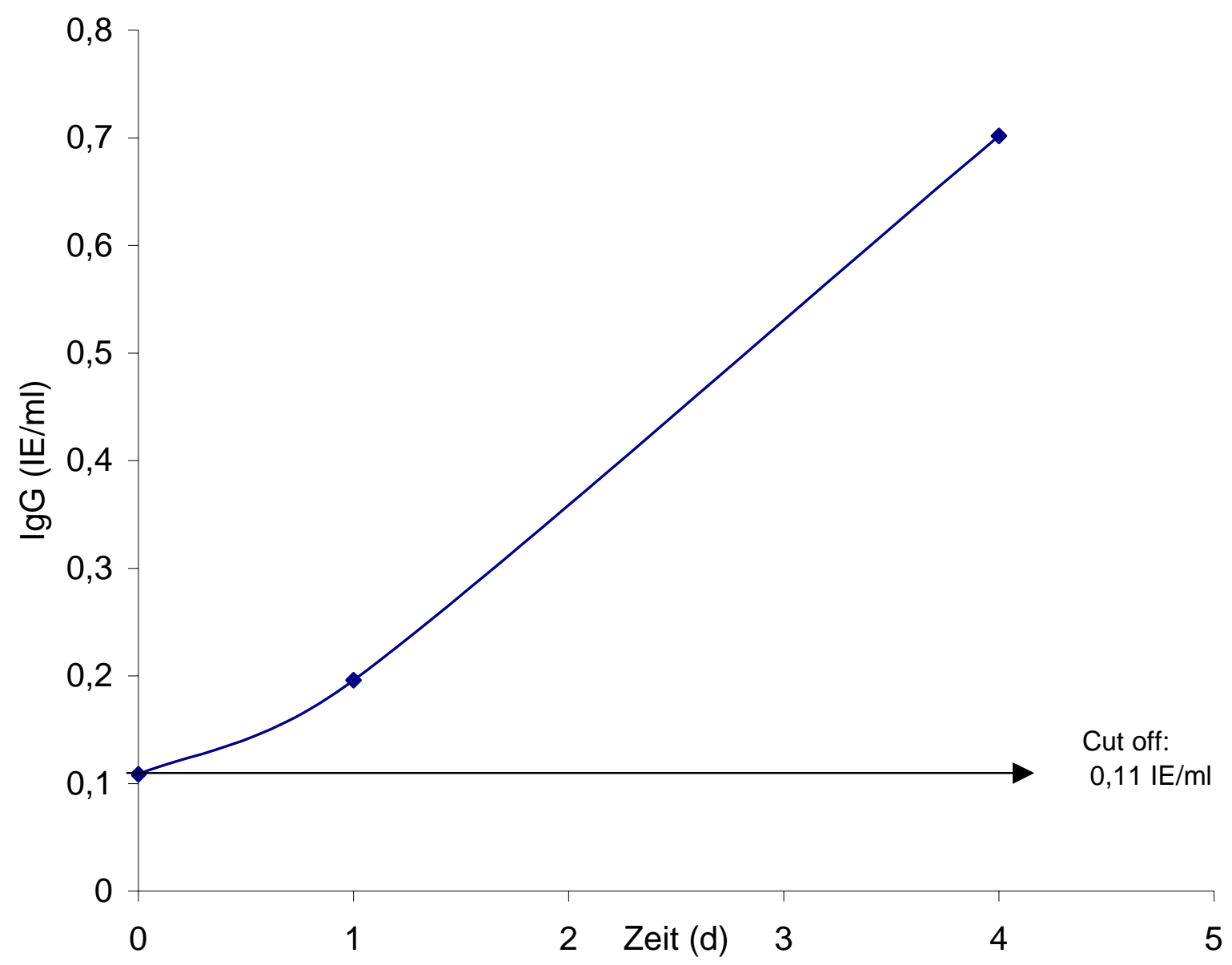

Abb. 19: Tetanusspezifischer Antitoxintiter bei einem an Tetanus erkrankten Fohlen 


\subsection{Diskussion}

\subsubsection{Antitoxingehalt im Fohlenserum}

In dieser Untersuchungsgruppe wurden Serumproben derjenigen Fohlen der in Kapitel 5.1.5 untersuchten Stuten analysiert. Alle Fohlen wurden ohne Komplikationen im regulären Trächtigkeitszeitraum geboren. In den ersten Lebensstunden nahmen alle Fohlen Kolostrum ihrer Mütter in ausreichenden Mengen auf.

Die Ergebnisse der Versuche der vorliegenden Arbeit zeigten, dass der Gehalt der maternalen Antikörper im Serum von Fohlen bereits nach durchschnittlich 66 Tagen unter den Cut off fällt.

Die Plazenta der Stute ist durch sechs histologische Schichten charakterisiert. Aus diesem Grund ist die Diffusionsstrecke durch die Plazenta für Moleküle sehr lang. Es findet kein Austausch zwischen maternalem und fetalem Kreislauf statt (Triskatis, 2004). Im letzten Drittel der Trächtigkeit ist ein geringgradiger Transfer maternaler Immunglobuline bedingt durch Auflockerungen des Chorionepithels und damit einer Verkürzung der Diffusionsstrecke möglich. Im gleichen Zeitraum ist es dem Fetus möglich, eigene Immunglobuline (IgG, IgM) auf einen Antigenreiz hin zu sezernieren. Der Grad der Immunantwort reicht jedoch nicht aus, um protektive Titer im fetalen Kreislauf zu erreichen (Thein, 1983). Erst nach Aufnahme des ersten Kolostrums können Immunglobuline im Fohlenblut nachgewiesen werden (Burton et al., 1981). Immunglobuline aus Kolostrum können nur innerhalb der ersten 20 Lebenstunden aufgenommen werden. Der Ort der Immunglobulinresorption ist der gesamte Dünn- und Dickdarm (Tizard, 2000). Die Aufnahme der maternalen Antikörper erfolgt aktiv über Pinozytose durch die Darmzellen des neonatalen Intestinaltraktes. Der Immunglobulingehalt des Fohlenserums entspricht nach Kolostrumaufnahmen dem Gehalt des maternalen Serums (Jeffcott, 1975, Thein, 1983). McGUIRE et al. (1977) und BURTON et al. (1981) konnten nachweisen, dass Fohlen mit ausreichender Kolostrumaufnahme einen IgG-Spiegel besitzen, der denen erwachsener Pferde entspricht. Diese These stimmt mit den eigenen Befundungen überein, wonach der durchschnittliche tetanusspezifsche IgG-Gehalt in den Fohlemseren während der ersten Lebenstage dem Antitoxingehalt im Blut ihrer Mütter entsprach. Über die Lymphe gelangen die Immunglobuline in die Blutbahn. Endogen sezernierte Trypsininhibitorem im Kolostrum verhindern die Proteolyse der Immunglobuline im neonatalen Verdauungstrakt (Jeffcott, 1975; Thein, 1983). 
Bereits 20 Stunden nach der Geburt beginnt der Austausch der unspezialisierten Darmzellen durch spezialisierte epitheliale Darmzellen. Diese haben die Fähigkeit zur Absorption von Makromolekülen verloren. Dieser Mechanismus wird durch Nebennierenhormone reguliert. Das Absorptionsmaximum des Fohlendarmes liegt bei drei bis sechs Stunden p. p. Zeitgleich setzt die enzymatische Proteolyse der Immunglobuline ein (Jeffcott, 1976; Kim und Schmidt, 1983). Die Halbwertzeit von equinem IgG liegt bei 22 Tagen, deshalb sind die maternalen Antikörper nach ca. sechs bis acht Wochen abgebaut (Mc Dougal, 1975; Perryman, 1981). In der vorliegenden Untersuchung sanken die tetanusspezifischen Serumtiter der Fohlen kontinuierlich ab und unterschritten nach ca. 66 Tagen den Cut off. Ab diesem Zeitpunkt wurden die Fohlen als seronegativ beschrieben. In Übereinstimmung mit diesen Ergebnissen fanden MAYR et al. (1993) einen zwei- bis dreimonatigen maternalen Schutz von Fohlen gut immunisierter Mütter. Im Gegensatz dazu haben VALETTE und PETERMANN (1980) einen vier Monate andauernden passiven Schutz bei Fohlen festgestellt. Die relativ große individuelle Schwankungsbreite der tetanusspezifischen Antitoxingehalte in den Fohlenseren in den ersten Lebenstagen könnte ursächlich im unterschiedlichen IgG-Gehalt im Kolostrum ihrer Mütter begründet sein. Da die Antikörperaufnahme und -speicherung durch das Fohlen endogen und physikalisch limittiert ist, kommt der Beeinflussung des Antitoxingehaltes im Kolostrum durch Boosterimpfungen der trächtigen Stuten besondere Bedeutung zu.

\subsubsection{Titerverlauf nach Grundimmunisierung bei Saugfohlen}

Der Kurvenverlauf nach zwei Grundimmunisierungen stimmt nur teilweise mit TIZARD (2004) überein, wonach die Immunreaktion nach der ersten Immunisierung durch eine längere lag-Phase (bis zu einer Woche) sowie niedrige und kurzzeitig messbare Antitoxintiter gekennzeichnet ist. Die Gabe der zweiten Impfung führte wie bei TIZARD (2004) zu einer verkürzten lag-Phase und einer stärkeren Immunreaktion. Die Anfangstiter der Fohlen lagen mit 0,107 IE/ml unter dem Cut off-Wert. Bereits zwei Tage nach der initialen Vakzinierung reagierten die Fohlen mit einer geringgradigen Immunantwort auf durchschnittliche Werte von 0,251 IE/ml und auf 0,377 IE/ml am 10. Tag. Ca. drei Wochen nach der ersten Grundimmunisierung erreichten die Titer Maximalwerte, um danach wieder abzufallen. Die zweite Grundimmunisierung erfolgte bei einem durchschnittlichen Antitoxingehalt im Serum von 0,78 IE/ml. Die zweite Impfung führte zu einem unmittelbaren Anstieg der tetanusspezifischen Antikörper im Serum. Der Erstkontakt von B-Lymphozyten mit dem 
Toxoid initiiert die Immunreaktion, in deren Folge die B-Lymphozyten in immunglobulinsezernierende Plasmazellen prozessiert werden. B-Zellen können sich während dieser Prozessierung in sogenannte Gedächtniszellen transformieren. Nach erneutem Antigenkontakt sind diese in der Lage, unmittelbar mit der Produktion von Immunglobulinen zu reagieren (Roitt et al., 2001). Die zweite Tetanusvakzinierung führte bei den Saugfohlen zu einem unmittelbaren Anstieg der Antitoxintiter in Bereiche deutlich über dem Grenzwert, wohingegen MAYR (1993) erst 10-14 d nach der zweiten Immunisierung belastbare Immunreaktionen feststellte. Die Stärke der Immunreaktion war größer und langanhaltender als bei der ersten Impfung. In diesem Betrieb wurde die zweite Grundimmunisierung nach nach 33 d appliziert. Das Impfregime entspricht damit der heute üblichen Verfahrensweise von einem Impfabstand von ca. vier Wochen. Nach den Empfehlungen der WHO (1993) sollte zur Erreichung maximaler dauerhafter Titer die zweite Grundimmunisierung auf dem Höhepunkt der Immunreaktion der ersten Vakzinierung gegeben werden. In diesem Fall bedeutet dies, dass die zweite Grundimmunisierung bereits um den 23. Tag nach der ersten Grundimmunisierung gegeben werden sollte. Im Gegensatz dazu propagiert MAYR (1993) einen achtwöchigen Abstand bei Saugfohlen zwischen beiden Grundimmunisierungen. Im Gegensatz zur grundimmunisierten Gruppe zeigte die Kontrollgruppe keine Veränderung des tetanusspezifischen Serum-IgG-Spiegels. Das Ergebnis widerspricht dem aktuellen Wissensstand, wonach messbare maternale Antitoxintiter die Entwicklung der aktiven Immunantwort inhibieren (Tizard, 2004). WINSNES et al. (1989) und WILSON et al. (2001) wiesen inhibitorische Effekte der mit dem Kolostrum aufgenommenen maternalen Antikörper auf die Immunantwort nach Tetanusvakzinierung nach. Sie schlossen daraus, dass Fohlen nicht vor einem Alter von sechs Monaten - erst nach dem Absetzen - tetanustoxidimmunisiert werden sollten. In den Seren der untersuchten Fohlen wurden tetanusspezifische AnfangsAntikörpertiter festgestellt, die aber unter dem Cut off lagen. Trotz der messbaren Antikörpergehalte haben die Fohlen auf die erste Tetanusgrundimmunisierung mit einem Anstieg der Antikörpertiter über den Cut off reagiert. Möglicherweise ist nicht allein das Vorhandensein von maternalen Antikörpern im Fohlenserum für die Inhibition der Immunantwort verantwortlich. Nachfolgende Arbeiten könnten klären, welchen Einfluss die Höhe des passiven maternalen Schutzes auf die Entwicklung einer aktiven Immunantwort hat. Die Immunisierungsversuche zeigten, dass bereits drei bis vier Monate alte Saugfohlen langanhaltende Anti-Tetanustiter entwickeln konnten. Das Ausbleiben einer Immunreaktion bei Fohlen unter drei bis vier Monaten könnte somit ihre Ursache nicht in der inhibitorischen Wirkung maternaler Antikörper haben. Vielmehr scheint das partiell inkompetente 
Immunsystem sehr junger Fohlen die Ausbildung tetanusspezifischer Serumtiter zu unterbinden. Für die Praxis bedeutet dies, dass die Tetanusimmunisierung von Fohlen, zumindest mit monovalentem Impfstoff, bereits ab dem dritten bis vierten Lebensmonat durchgeführt werden könnte. Die dauerhafte Milchaufnahme von der Mutterstute scheint für die Entwicklung tetanusspezifischer Antitoxintiter keine Rolle zu spielen, da das ältere Fohlen nicht in der Lage ist, Antikörper über den Darm aufzunehmen. Weiterführende Untersuchungen könnten den Zeitraum zwischen dem Unterschreiten des Cut off und der Entwicklung eines Tetanusimmunschutzes nach Vakzinierung enger charakterisieren sowie den Einfluss von mono- und polyvalenten Impfstoffen auf die Entwicklung der Immunantwort bei Fohlen.

\subsubsection{Titerverlauf von Altstuten nach Boosterung}

Der Antitoxingehalt zu Beginn betrug durchschnittlich 0,63 IE/ml. Er lag damit deutlich über dem Cut off von 0,11 IE/ml. Alle Stuten dieser Untersuchungsgruppe wurden als tetanusantitoxin-seropositiv eingestuft. Am 72. Tag nach Untersuchungsbeginn wurden die Stuten im Rahmen des gestütsinternen Impfregimes mit Tetanus-Influenza-Vakzine geboostert. Bereits einen Tag nach Vakzinierung wurde ein Anstieg des tetanusspezifischen IgG-Gehaltes von 1,07 IE/ml am drittletzten Tag vor der Impfung auf 1,54 IE/ml beobachtet. Die Ergebnisse stimmen mit TIZARD (2004) überein, wonach Boosterimpfungen gut immunisierter Pferde zu einer kurzen lag-Phase <2-3 d führen, ehe der Antikörpergehalt sprunghaft ansteigt. Das Immunsystem reagiert mit einem wiederholten Antigenreiz mit einer sofortigen und verstärkten Sezernierung von Immunglobulinen IgG durch Gedächtniszellen (Wecker, 1990). Am neunten Tag nach der Boosterung erreichten die Werte ihr Maximum von 13,95 IE/ml (Schwankungsbreite angeben). Innerhalb der nächsten 20 Tage fielen die Antitoxingehalte auf durchschnittliche Werte von 7,93 IE/ml (Schwankungsbreite angeben). Die wiederholte Immunisierung von Tetanustoxoid (Boosterung) führte zu einem höheren Immunglobulinniveau im Blut (Tizard, 2000). 


\subsubsection{Antitoxintiterentwicklung bei Jährlingen}

Der Kurvenverlauf der Serum-Antitoxintiter bei Jährlingen nach Tetanusvakzinierung entspricht im Wesentlichen TIZARD (2004). Die Primärvakzinierung ist durch eine lange lagPhase von sieben Tagen charakterisiert, in deren Verlauf der tetanusspezifische Antikörpergehalt nicht über den Cut off steigt. Nach ca. 22 d erreichten die Titer ein Plateau mit Maximalwerten von 0,64-0,68 IE/ml, die mindestens bis zum 29. Tag anhielten. Die zweite Grundimmunisierung erfolgte 30 d nach der ersten Vakzinierung. Diese führte zu einer Immunreaktion mit einer kürzeren lag-Phase. Einen Tag nach der zweiten Impfung hatten die Pferde Titer von durchschnittlich 0,69 IE/ml. Aus logistischen Gründen wurden erst am 36. Tag wiederholt Proben gewonnen. An diesem Untersuchungstag hatten die Tiere bereits Titer von durchschnittlich 10,65 IE/ml.

Die Kinetik der Antikörperbildung nach Tetanusgrundimmunisierung weist deutliche Unterschiede bei Saugfohlen und Jährlingen auf.

\begin{tabular}{|c|c|c|}
\hline Parameter & Saugfohlen & Jährlinge \\
\hline maternale Antikörper & messbar, aber <Cut off & nicht nachweisbar \\
\hline lag-Phase nach 1. Impfung & $2 \mathrm{~d}$ & $7 \mathrm{~d}$ \\
\hline Maximalwerte nach & $22 \mathrm{~d}$ & $22 \mathrm{~d}-$-mindestens 29 d \\
\hline lag-Phase nach 2. Impfung & $1-2 \mathrm{~d}$ & $2-3 \mathrm{~d}$ \\
\hline
\end{tabular}

Tab. 9: Kinetik der tetanusspezifischen Antikörperbildung bei Saugfohlen und Jährlingsstuten

Unter Berücksichtigung der Diversität der applizierten Vakzine (Valenz, Produktdefinition) lassen sich auf Grund der vorliegenden Daten folgende Schlüsse zum konkreten Impfmanagement ziehen:

- zumindest maternale Antikörper $<$ Cut off verhindern nicht die Bildung tetanusspezifischer Antikörpertiter bei Saugfohlen

- die lag-Phase nach der ersten und zweiten Immunisierung ist bei Saugfohlen kleiner als bei Jährlingen; tetanusspezifische Titer $>0,11 \mathrm{IE} / \mathrm{ml}$ wurden bei Saugfohlen bereits nach zwei Tagen gemessen

- die zweite Immunisierung sollte bei Saugfohlen pünktlich nach drei Wochen gesetzt werden 
- für die Gabe der zweiten Impfung bei älteren Tieren steht ein größeres Zeitfenster offen; die Serumwerte stagnieren ab dem 22. Tag bis mindestens zum 29. Tag; die zweite Immunisierung kann nach drei bis vier Wochen erfolgen, gegebenenfalls einige Tage später.

\subsubsection{Antitoxintiter in Stutenkolostrum und Milch}

Das Kolostrum ist ein von Säugetieren zum Zweck der Aufzucht ihrer Jungen zu Beginn der Laktation abgegebenes energiereiches Sekret. Mit zunehmender Laktationsdauer sinkt die Konzentration von Proteinen, Vitaminen und Mineralstoffen. Da die Plazenta der Stute für Immunglobuline weitestgehend undurchlässig ist, spielt die Aufnahme von Kolostrum durch das Fohlen in den ersten Lebensstunden eine herausragende Rolle (Thein, 1983). In den letzten Trächtigkeitswochen findet eine selektive Anreicherung der Immunglobuline in der Milchdrüse statt (Smith et al., 1971). Der Milchfluss wird hormonell durch die Geburt und das Saugverhalten des Fohlens gesteuert. Bereits neun Stunden p. p. wird in zunehmendem Maße IgA in das Kolostrum abgegeben. Es kommt zu einer Verschiebung des IgA/IgGQuotienten zu Gunsten des IgA (McGuire und Crawford, 1972, Thein, 2003, Smith et al., 1971). In den ersten Tagen p. p. war das Kolostrum stark IgG-haltig. In den ersten sieben Laktationstagen sank der IgG-Titer im Kolostrum von Werten von durchschnittlich 52 IE/ml am Tag 0 auf 0,161 IE/ml am siebten Tag post partum. Zwischen dem siebten und 14. Laktationstag unterschritt der Antitoxingehalt den Cut off. Diese Ergebnisse stimmen mit TIZARD (2004) überein, wonach der Immunglobulingehalt des Kolostrums nach einem Maximum am ersten Tag p. p. stetig fällt. MAYR (1993) fand in Übereinstimmung mit den eigenen Versuchsergebnissen den Verlust des maternalen tetanusspezifischen IgG nach sieben bis zehn Tagen p. p.

Immunglobulin A besitzt keine neutralisierenden antitoxischen Eigenschaften. Im praktischen Fall bedeutet es, dass unbedingt sicherzustellen ist, dass das Fohlen in den ersten Lebensstunden Anfangskolostrum erhält. Die geringe Tetanus-Erkrankungsrate von nichtimmunisierten Saugfohlen ist wahrscheinlich auf den hohen IgA-Gehalt der Milch zurückzuführen. Aus diesem Grund sollten nicht grundimmunisierte Fohlen längstmöglich gesäugt werden.

Auf Grund der geschilderten Veränderungen des Plazentaepithels im letzten Trimenion (Thein, 1983) ist es denkbar, den IgG-Gehalt des Kolostrums bei immunkompetenten 
vollimmunisierten Stuten durch die geburtsnahe Gabe einer Tetanustoxoidboosterung positiv zu regulieren. Diese These stimmt mit den Beobachtungen von SEIFERT und BÖHNEL (1995) überein. Sie schlugen vor, dass tragende immunisierte Tiere geburtsnah, ca. vier Wochen a. p., geboostert werden sollten, um möglichst hohe Anfangskolostrumwerte zu erhalten. MAYR (1993) befürwortet ebenfalls die Boosterung von trächtigen Stuten während des letzten Trimenions. Tetanustoxoidboosterung von tragenden Stuten einen bzw. zwei Monate a. p. führte zu Antikörpergehalten >0,1 IE/ml über mehrere Monate im Fohlenserum (Rossdale und Scarnell, 1961).

\subsubsection{Fallbeispiel}

TIZARD (2004) beschreibt die Kinetik des IgG-Gehaltes bei Pferden nach Gabe von homologen Antitoxin. Hiernach steigt der Serum-IgG-Gehalt unmittelbar nach intravenöser, mit einiger zeitlicher Verzögerung nach intramuskulärer, Applikation von Hyperimmunglobulin an, um über einen Zeitraum von mehreren Wochen kontinuierlich abzufallen. Die wiederholte Gabe von tetanusspezifischem IgG (Serumtherapie) sollte das Phänomen verstärken.

Möglicherweise wird tetanusspezifisches IgG im gesunden Tier in anderer Weise metabolisiert als beim Akutkranken. In der Primärläsion gebildetes und freigesetztes Tetanustoxin wird von den peripheren Nervenendigungen resorbiert. Die Wanderung des Toxins in den Nerven erfolgt zu den motorischen Spinalganglien, in deren Folge die innervierten Muskeln reflexartig kontrahieren. Bei einer hohen Toxinproduktionsrate sind die Nerven unter Umständen nicht mehr in der Lage, Toxin aufzunehmen. Es wird über die Lymphe ins Blut und dann ins ZNS transportiert (Seifert und Böhnel, 1995). Wird einem an Tetanus erkrankten Pferd IgG (intramuskulär/intravenös) verabreicht, kann dieses IgG ausschließlich im Blut zirkulierendes Toxin neutralisieren. Im ELISA werden jedoch nur freie Antikörper bestimmt. Zu Beginn der Therapie zirkuliert eine große Menge Toxin, das von einem Großteil des verabreichten Antitoxins neutralisiert wird. Hieraus könnten sich die relativ niedrigen Antitoxingehalte unmittelbar nach Therapiebeginn erklären. Im Gegensatz zum kranken Tier wird beim nicht an Tetanus erkrankten Pferd das gesamte verabreichte tetanusspezifische IgG titriert.

Eine andere Erklärung ist der sogenannte „high dose hook effect/Prozonenphänomen“ Meyer und Bellwinkel, 1990). Die Antikörper liegen nach Serumtherapie in einer sehr hohen 
Konzentration im Blut vor. Durch diesen Überschuss kann es im ELISA zur Auflösung der Präzipitatkomplexe und damit zur Bestimmung falsch niedriger Proben kommen. Die Überprüfung dieser These könnte durch zusätzliche Probenverdünnungen erfolgen. 


\section{Zusammenführende Diskussion und Schlussfolgerungen}

\section{1 Zusammenführende Diskussion}

Im ersten Teil der hier vorgelegten Dissertationsschrift sollte ein Alternativverfahren auf Basis eines ELISA zur quantitativen Bestimmung von equinem tetanusspezifischem IgG entwickelt werden. Der zweite Teil der Arbeit beinhaltete die praktische Anwendung des Verfahrens zum Monitoring des Impfstatuss’ vor und nach Tetanustoxoidvakzinierung in einem großen Pferdebestand.

Der entwickelte und validierte ELISA ist ein indirekter ELISA. Als Fangantigen wurde Tetanustoxid verwendet. Sowohl Tetanustoxoid als auch Tetanustoxin zeigten eine gute Korrelation der Standardverdünnungen zu ihren optischen Dichten. Als Probenmatrizes können sowohl Serum-, als auch EDTA, Zitrat- oder Heparinplasma eingesetzt werden. Verdünnungsversuche haben gezeigt, dass Serumproben hundertfach verdünnt werden müssen. Der Sekundärantikörper ist ein meerrettichperoxidase konjugierter Kaninchen-antiPferd-IgG-Antikörper.

An einer Gruppe nichtimmunisierter Jungstuten im Alter von 10-12 Monaten wurde der Cut off bestimmt. Dieser liegt methodenspezifisch in diesem Test bei 0,11 IE/ml Serum. An einem praktischen Fall aus der Pferdeklinik des fzmb konnte gezeigt werden, dass bei einem an generalisiertem Tetanus erkrankten Fohlen nach Überschreiten des Cut off durch Hyperimmunglobulinabe eine Verbesserung des Gesundheitszustandes erreicht wurde. Von der WHO (1993) wurde eine gute Korrelation zwischen in vivo-Assay und ELISA bestätigt, wobei 0,01 IE/ml im Neutralisationstest als Grenzwert für protektive Titer beim Menschen 0,1 IE/ml im ELISA entsprechen sollen. Die Validität des ELISA wurde für Serumproben anhand verschiedener Parameter verifiziert. So wurde die Intraassayvarianz $<5 \%$ und die Interaassayvarianz mit $11 \%$ bestimmt. Die Werte lagen damit unter der von der OIE (2004) für veterinärmedizinische in vitro-Diagnostika vorgeschlagenen Richtwerte. Der Vergleich mit kommerziellen Tests aus der Humanmedizin ergab für den Pferde-ELISA gute Ergebnisse. Die Sensitivität des Verfahrens wurde mit 89,7 \% angegeben. Die Überprüfung des Ergebnisses mit der Referenzmethode steht noch aus. Die Spezifität der Methode wurde für die C. botulinum-Toxine A, B, C und D nachgewiesen.

Eine Modifikation des Serum-ELISA stellte der Milch- bzw. Kolostrum-ELISA dar. Der methodische Aufbau und Ablauf wurde direkt vom Serum-ELISA übernommen. Die Modifikation bestand in der veränderten Probenaufarbeitung. Die Probenaufarbeitung der 
Milch/Kolostrumproben wurde von WINTERHOFF (2000) adaptiert. Grundlage ist die Dicklegung der Milch durch Labzusatz und anschließende Inkubation der Probe bei $37^{\circ} \mathrm{C}$ im Wasserbad. Im Gegensatz zu Serum stellt Kolostrum bzw. Milch nur ein saisonal verfügbares Medium dar. Beide sind vitamin-, energie- mineralstoff- und proteinreiche Sekrete. In Kolostrum liegt ein deutlicher Überschuss von IgG zu IgA vor. Dieses Verhältnis verschiebt sich ab 20 Stunden p. p. zu Gunsten des IgA. Da das Fohlen ohne maternale Antikörper geboren wird, stellt die Aufnahme von Kolostrum das Hauptkriterium für die Entwicklung protektiver Antitoxintiter beim neugeborenen Fohlen dar. Mittels des modifizierten ELISA konnten die maternalen IgG-Titer zeitabhängig in Milch und Kolostrum bestimmt werden. Mit dem entwickelten Verfahren wurden Kontroll-und Titerverlaufstudien an unterschiedlichen Untersuchungsgruppen gemacht.

Bei neugeborenen Fohlen sank der protektive Tetanustiter innerhalb der ersten 66 Lebenstage unter den Grenzwert ab. Dieser relativ kurzzeitige Schutzeffekt ist zum Einen in der begrenzten Abgabe von protektiv wirkendem, maternalen IgG über das Kolostrum bedingt. Auf der anderen Seite kann das Fohlen IgG nur innerhalb der ersten 20 Lebensstunden über die Darmschleimhaut aufnehmen. Aufgenommenes IgG hat eine intrinsische Halbwertzeit von 22 Tagen. Das heißt, dass in Abhängigkeit von der Menge der aufgenommenen IgG der maternale Schutz innerhalb der ersten sechs bis acht Lebenswochen erlischt. Zwischen dem siebten und 14. Tag p. p. sanken die IgG-Titer in der Milch unter den Cut off. Mit der kontinuierlichen Aufnahme von reifer, IgA-reicher Milch könnte das zeitlich distinkte Risikofenster vom Erlöschen des maternalen Schutzes bis zur Tetanusgrundimmunisierung überbrückt werden. Möglicherweise ist die Auskleidung der Darmschleimhaut mit IgA beim Saugfohlen für die niedrige Erkrankungsrate während des Saugalters verantwortlich. Mit der Immunisierung von drei bis vier Monate alten Saugfohlen konnte bewiesen werden, dass das Immunsystem der Tiere in diesem Alter in der Lage ist, auf die Verabreichung von zwei Dosen monovalentem Tetanusimpfstoff mit der Produktion spezifischer Antitoxintiter zu reagieren. Der Titerverlauf nach initialer und zweiter Grundimmunisierung mit TetanusInfluenza-Vakzine wurde bei einjährigen Jungstuten verfolgt. Wie die Saugfohlen im vorher geschilderten Immunisierungsversuch reagierten die Jährlinge mit einem langsamen Anstieg der Antioxingehalte im Serum. Die Applikation der zweiten Grundimmunisierungsdosis führte zu einer sofortigen gesteigerten Immunreaktion mit einer belastbaren dauerhaften Immunität. 


\subsection{Schlussfolgerungen}

Der in dieser Arbeit entwickelte und validierte ELISA ist ein geeignetes Verfahren zur Tetanus-Impfkontrolle bei Pferden. Inwieweit die gemessenen tetanuspezifischen Titer tatsächlich protektiven Charakter besitzen, wurde nicht geklärt. Dieser Sachverhalt könnte der Ausgangspunkt folgender Untersuchungen sein. Wahrscheinlich kann der ELISA den MausAssay nicht vollständig ersetzen. Möglicherweise ergeben sich insbesondere im niedrigtitrigen Bereich Differenzen gegenüber der Referenzmethode. Dieses Phänomen wurde von verschiedenen Stellen für ELISAs beschrieben, ohne dass dieser Effekt innerhalb dieser Arbeit näher charakterisiert wurde. In zukünftigen Arbeiten sollten grenzwertige Serumtiter mittels der Referenzmethode abgeglichen werden. Der für dieses Verfahren methodenspezifische Cut off war in einem praktischen Fall tatsächlich mit der Entwicklung klinischer Erscheinungen korreliert. Aus den Ergebnissen der Felduntersuchungen lassen sich folgende Schlüsse hinsichtlich des Impfmanagements ziehen:

- Da der maternale tetanusspezifische Antikörperschutz nach ca. zwei Monaten p. p. erlischt, können bereits Saugfohlen tetanusgrundimmunisiert werden

- Die Impfungen bei Saugfohlen sollten im Abstand von drei Wochen gegeben werden

- Da Kolostrum die einzige natürliche Quelle passiver Antikörper für das Fohlen ist, muss sichergestellt sein, dass das Fohlen Anfangskolostrum (0-24 h p. p.) erhält

- Bekommt das Fohlen aus unterschiedlichen Gründen kein Anfangskolostrum, sollte das Fohlen mit Tetanushyperimmunglobulin passiv immunisiert werden

- Tragende, gut immunisierte Stuten sollten vier bis acht Wochen a. p. geboostert werden, um den IgG-Gehalt im Kolostrum positiv zu regulieren

- Die Grundimmunisierung von älteren Tieren (>ein Jahr) kann im Abstand von vier bis fünf Wochen durchgeführt werden.

Für spätere Felduntersuchungen ergeben sich folgende Ziele:

- Überprüfung der tatsächlichen anti-Tetanus-protektiven Wirkung der gemessenen Antikörper

-Abgleichen des ELISA mit der amtlichen Referenzmethode; Bestimmung von Nachweisgrenzen 
- Eingrenzung des Zeitraumes vom Erlöschen des maternalen Immunschutzes bis zur Möglichkeit der Grundimmunisierung von Saugfohlen

- produktspezifische Untersuchungen von Impfstoffen zur Entwicklung tetanusspezifischer Titer bei Saugfohlen und erwachsenen Tieren; insbesondere Klärung der Stärke und Dauer der Immunantwort bei mono-, di- und polyvalenten Impfstoffen sowie gegebenenfalls Wechselwirkungen im Organismus

- produktspezifische Untersuchungen von Impfstoffen zur Entwicklung tetanusspezifischer Antitoxintiter in Kolostrum 


\section{$7 \quad$ Zusammenfassung}

Entwicklung und Validierung eines ELISA zur Beurteilung der Tetanusvakzinierung am Beispiel eines Pferdebestandes in Thüringen.

Tetanus ist eine seit dem Altertum bekannte Erkrankung bei Menschen und verschiedenen Tierarten. Insbesondere Pferde sind hoch empfindlich gegenüber dem die Erkrankung auslösenden Tetanustoxin (Tetanospasmin). Der einzig wirksame Schutz gegen Tetanus stellt die Immunisierung mit Toxoidimpfstoffen dar. Die Referenzmethode zur Überprüfung der Wirksamkeit von Tetanusimpfstoffen ist der in vivo-Maus-/Meerschweinchen-Assay. Auf Grund der für Tierversuche im allgemeinen geltenden strengen Restriktionen kann mit diesem Verfahren keine routinemäßige Kontrolle des Impfstatuss’ erfolgen. Die vorliegende Dissertation hatte das Ziel, ein geeignetes immunologisches Verfahren zu entwickeln, um eine regelmäßige Überprüfung des Impferfolges bei Pferden zu ermöglichen. Ein zweiter Schwerpunkt war das Monitoring des maternalen tetanusspezifischen IgG-Gehaltes in Kolostrum und Fohlenserum.

Es wurden folgende Ergebnisse erzielt:

- Der entwickelte ELISA stellt ein geeignetes Verfahren zur Bestimmung und Titerverlaufkontrolle des tetanusspezifischen IgG-Gehaltes dar.

- Der methodenspezifische Cut off wurde für dieses Verfahren mit 0,11 IE/ml bestimmt.

- Der maternale IgG-vermittelte Schutz von Saugfohlen sinkt nach durchschnittlich 66 Tagen unter den Cut off. Die Fohlen wurden ab diesem Zeitpunkt als seronegativ eingestuft.

- Zwischen dem 7. und 14. Tag p. p. sanken die IgG-Gehalte in der Stutenmilch unter den Cut off.

- Die Grundimmunisierung gegen Tetanus kann bereits bei Saugfohlen durchgeführt werden.

Die Vakzinierung mit monovalentem Tetanusimpfstoff führte bei drei bis vier Monate alten Fohlen zu einer guten Immunantwort mit hohen tetanusspezifischen Antitoxingehalten. Die zweite Impfdosis sollte pünktlich nach drei Wochen appliziert werden.

- Die zweite Grundimmunisierung bei älteren Pferden (>ein Jahr) kann vier, gegebenenfalls fünf Wochen nach der ersten Impfung verabreicht werden

- Zur Förderung maximaler maternaler Tetanusantitoxintiter im Kolostrum sollte die TetanusBoosterung tragender immunisierter Stuten in den letzten vier bis acht Wochen a. p. vorgenommen werden. 


\section{Summary}

Development and validation of an ELISA for the judgement of tetanus vaccination in a stock of horses in Thuringia.

Tetanus is a well-known disease of humans and different species of animals since the antiquity. Especially horses are sensitive towards tetanospasmin, which is the final agent causing tetanus. Vaccination with toxoid vaccines is the only effective protection against tetanus. The reference method for checking the effectivity of tetanus vaccines is the mouse/guinea pig -in vivo neutralization test. Since animal tests are strongly restricted, there is no possibility for a routine control of the status of vaccination of horses.

For this reason, the aim of this thesis was to develop an immunological test for routine control of the status of vaccination of horses. A second aim was the monitoring of the maternal tetanusspecific IgG-content in colostrum of mares and in the serum of their foals.

Following results were reached:

- This ELISA is a suitable method for the detection and the trend control of the tetanusspecific IgG-content in horse blood

- The cut off for this method is $0,11 \mathrm{IE} / \mathrm{ml}$

- The maternal associated protection against tetanus decrease after 66 days under the cut off. From this time the foals were classified as seronegativ

- Between the $7^{\text {th }}$ and $14^{\text {th }}$ day p. p. the IgG-contents in foal serum decreased below the cut off

- The basic immunization of foals against tetanus can be carried out before they were separated from their mothers

- The vaccination with monovalent tetanus vaccine of three to four month old foals caused a satisfying immune answer with high tetanusspecific content of antitoxin. The second dose of vaccine should be administerd exactly after three weeks

- The second immunization of horses older than one year can be given four or five weeks after the first vaccination

- To support maximum maternal tetanus antitoxin titer in the colostrum the tetanus booster of immunized pregnant mares should be made in the last four to eight weeks a. p. 


\section{$9 \quad$ Literatur}

AKULINICHEWA, K. V. (1989): C. tetani vitality under aerobic conditions: hypothesis and facts. In: NISTICO, G., B. BIZZINI, B. BYTCHENKO, R. TRIAU (eds.) Eighth int conf tetanus.

Pythagora Press, Rom: 20-25

ANDERSON, R., X.-M. GAO, A. PAPAKONSTANTINOPOULOU, M. ROBERTS, G. DOUGAN (1996) : Immune response in mice following immunization with DNA encoding fragment $\mathrm{C}$ of tetanus.

Infect Immun 64: 3168-3173

ANGSTRÖM, J., S. TENEBERG, K.-A. KARLSSON (1994): Delineation and comparison of ganglioside-binding epitopes for the toxins of Vibrio cholerae, Escherichia coli, and Clostridium tetani: Evidence for overlapping epitopes.

Proc Natl Acad Sci 91: 11895-11863

ANONYM $_{\mathrm{a}}$ (2002): Europäisches Arzneibuch. Grundwerk. Band 1: Allgemeiner Teil.

Monographiegruppen.

Deutscher Apotheker Verlag, Stuttgart

ANONYM $_{\mathrm{b}}$ (2003): Tetanus Toxin/Tetanus Toxoid, Tetanus Toxin C-Fragment, C-Fragment Fluoresceinisothiocyanate Conjugat.

http://www.listlabs.com/Literature/190.htm; (letzter Zugriff am 09. 12. 2005)

ANONYM $_{c}$ (2003): Arbeitsanleitung Tetanus IgG ELISA.

http://www.ibl-hamburg.com, Version 1 (letzter Zugriff am 09. 12. 2005)

ANONYM $_{d}$ (2003): Gebrauchsanleitung “Immuzym Tetanus”.

http://www.progen.de (letzter Zugriff am 09. 12. 2005)

ANONYM $_{\mathrm{e}}$ (2000): DIN 58967-10. In: DIN-Taschenbuch 222: Medizinische Mikrobiologie und Immunologie. Diagnostische Verfahren.

3. Aufl., Beuth, Berlin: 71-77

ANONYM $_{\mathrm{f}}$ (2000): DIN 58967-30. In: DIN-Taschenbuch 222: Medizinische Mikrobiologie und Immunologie. Diagnostische Verfahren.

3. Aufl., Beuth, Berlin: 83-92

ANTONIN, W., C. HOLROYD, R. TIKKANEN, S. HÖNING, R. JAHN (2000): The RSNARE Endobrevin/VAMP-8 mediates homotypic fusion of early endosomes and late endosomes.

Mol Biol Cell 11: 3289-3298

AVRAMEAS, S., T. TERNYNCK (1998): Enzyme-linked immunosorbent assay (ELISA). In: DELVES P. J., ROITT I. M. (eds.) Encyclopedia of immunology. $2^{\text {nd }}$ ed., Academic Press, London: 816-819

BARTELS, F., H. BIGALKE (1992): Restoration of exocytosis occurs after inactivation of intracellular tetanus toxin.

Infect Immun 60: 302-307 
BERGEY, D. H. (1986): Manual of systematic bacteriology. $2^{\text {nd }}$ ed., Williams \& Wilkins, Baltimore

BEVERIDGE, T. J. (1990): Mechanism of gram variability in select bacteria.

J Bact 172: 1609-1620

BHATTACHARYYA, S. D., H. SUGIYAMA (1989): Inactivation of botulism and tetanus toxins by chelators.

Infect Immun 57: 3053-3057

BIZZINI, B. (1979): Tetanus toxin.

Microbiol Rev 43: 224-240

BIZZINI, B., A. A. FEDINEC (1989): Structural and functional characterization of tetanus toxin. Nomenclature. In: NISTICO, G., B. BIZZINI, B. BYTCHENKO, R. TRIAU (eds.) Eighth in conf tetanus.

Pythagora Press, Rom: 37-42

BIZZINI, B., A. TURPIN, E. HENOCQ, B. MARO: Tetanus immunization with a fluid pure monomeric toxoid administered by intradermal route. In: SEIFERT, H. S. H. und H. BÖHNEL (1995): Handbuch der bakteriellen Infektionen bei Tieren.

Fischer, Jena

BOLLWEIN, J. (2004): Serologische Untersuchungen von Sauenmilch und Ferkelblut als mögliche Alternative zur Blutuntersuchung von Muttersauen im Rahmen der Bestandsdiagnostik.

Diss med vet, Ludwig-Maximilian-Universität, München

BOUCHER, P., H. SATO, Y. SATO, C. LOCHT (1994): Neutralizing antibodies and immunprotection against pertussis and tetanus obtained by use of a recombinant pertussis toxin-tetanus toxin fusion protein.

Infect Immun 62: 449-456

BOUVET, J.-P-, L. BELEC, R. PIRES, J. PILLOT (1994): Immunoglobulin G antibodies in human vaginal secretions after parenteral vaccination.

Infect Immun 62: 3957-3961

BRANDIS, H., W. KÖHLER, H. J. EGGERS, G. PULVERER (1994): Lehrbuch der Medizinischen Mikrobiologie.

7. Aufl., Fischer, Stuttgart

BRÜGGEMANN, H. (2003): Die vollständige Entschlüsselung der Genomsequenz des Tetanuserregers Clostridium tetani und die Analyse seines genetischen Potentials.

Diss rer nat, Georg-August-Universtät, Göttingen

BRÜGGEMANN, H., S. BÄUMER, W. F. FRICKE, A. WIEZER, H. LIESEGANG et al. (2003): The genome sequence of Clostridium tetani, the causative agent of tetanus disease. Proc Natl Acad Sci 100: 1316-1321 
BRÜGGEMANN, H. und G. GOTTSCHALK (2003): Insights in metabolism and toxin production from the complete genome sequence of Clostridium tetani.

Anaerobe 10: 53-68

BURTON, S. C., H. F. HINTZ, M. J. KEMEN, D. F. HOLMES (1981): Lyophilized hyperimmune equine serum as a source of antibodies for neonatal foals.

Am J Vet Res 42, 308-310

CHARLES, I. G., B. C. RODGERS, A. J. MAKOFF, S. N. CHATFIELD, D. E. SLATER, et al. (1991): Synthesis of tetanus toxine fragment $C$ in insect cells by use of a Baculovirus expression system.

Infect Immun 59: 1627-1632

COOK, T. M., R. T. PROTHEROE, J. M. HANDEL (2001): Tetanus: a review of the literature.

Brit J Anaest 87: 477-487

COOPER, P. J., I. ESPINEL, M. WIESEMAN, W. PAREDES, M. ESPINEL, et al. (1999): Human onchocerciasis and tetanus vaccination. Impact on the postvaccination antitetanus antibody response.

Infect Immun 67: 5951-5957

COPLU, N., B. ESEN, A. GOZALAN, K. MIYAMURA, I. YOSHIDA, et al. (2004): Tetanus antibody assay combining in-house-ELISA and particle agglutination test and its serosurvey application in a province in Turkey.

Jpn J Infect Dis 57: 97-102

CORNILLE, F., L. MARTIN, C. LENOIR, D. CUSSAC, B. P. ROQUES, et al. (1997): Cooperative exosite-dependent cleavage of synaptobrevin by tetanus toxin light chain. Am Soc Biochem Mol Biol 272: 3459-3464

COX, C. B., C. HARDEGREE, R. FORNWALD (1974): Effects of tetanolysin on platelets and lysosomes.

Infect Immun 9: 696-701

CURTIS III, R. (2002) : Bacterial infectious disease control by vaccine developement. J Clin Invest 110: 1061-1066

DEMING, M. S., J.-B. ROUNGOU, M. KRISTIANSEN, J. HERON, A. YANGO, et al. (2002): Tetanus toxoid coverage as an inductor of serological protection against neonatal tetanus.

Bull World Health Org 80: 696-703

DUC, L. H., H. A. HONG, N. FAIRWEATHER, E. RICCA, S. M. CUTTING (2003):

Bacterial spores as vaccine vehicles.

Infect Immun 71: 2810-2818

EDSALL, G., B. HEYWORTH, I. McGREGOR, M. PEEL (1975): Malnutrition and the immune response to tetanus toxoid. In: Foundation Merieux (eds): Proc fourth int conf tetanus.

Lyon: 683-685 
EISEL, U., W. JARAUSCH, K. GORETZKI, A. HENSCHEN, J. ENGELS, et al. (1986): Tetanus toxin: primary structure, expression in E. coli, and homology with botulinum toxins. Eur Mol Biol Org J 5: 2495-2502

\section{EUROPEAN CENTRE FOR THE VALIDATION OF ALTERNATIVE METHODS} (ECVAM) (2000) $)_{\mathrm{a}}$ : Statement on the applications of the ELISA procedure for batch potency of tetanus vaccines for human use.

European Commission Joint Research Centre; Institut for Health \& Consumer Protection, ECVAM Unit

EUROPEAN CENTRE FOR THE VALIDATION OF ALTERNATIVE METHODS (ECVAM) (2000) : Statement on the applications of the ToBi test procedure for batch potency of tetanus vaccines for human use.

European Commission Joint Research Centre; Institut for Health \& Consumer Protection, ECVAM Unit

FAIRWEATHER, N. F., V. A. LYNESS (1986): The complete nucleotide sequence of tetanus toxin.

Nucl Acid Res 14: 7809-7812

FAIRWEATHER, N. F., V. A.LYNESS, D. J. PICKARD, G. ALLEN, R. O. THOMSON (1986): Cloning, nucleotide sequencing, and expression of tetanus toxin fragment $C$ in Escherichia coli.

J Bact 165: 21-27

FIGUEIREDO, D., C. TURCOTTE, G. FRANKEL, Y. LI, O. DOLLY, et al. (1995):

Characterization of recombinant tetanustoxin derivatives suitible for vaccine development. Infect Immun 63: 3218-3221

FORRAT, R., R. DUMAS, M. SEIBERLING, M. MERZ, C. LUTSCH, et al. (1998): Evaluation of the safety and pharmacokinetic profile of a new, pasteurized, human tetanus immunoglobulin administered as sham, postexposure prophylaxis of tetanus.

Antimicrob Agents Chemotherap 42: 298-305

FREDRICK, M. und D. O. ABRAHAMIAN (2001): Management of tetanus: a review. Curr Treat Opt Infec Dis 3: 209-216

GALAZKA, A. M. (1975): Serological methods. Practical evaluation of immunity and susceptibility. In: Foundation Merieux (eds): Proc fourth int conf tetanus.

Lyon: 687-706

GALLI, T., A. ZAHRAOUI, V. V. VAIDYANATHAN, G. RAPOSO, J. M. TIAN, et al. (1998): A novel tetanus neurotoxin-insensitive vesicle-associated membrane protein in SNARE complexes of the apical plasma membrane of epithelial cells.

Mol Biol Cell 9: 1437-1448

GIL, C., I. CHAIB-OUKADOUR, J. BLASI, J. AGUILERA (2001) : H terminal portion of the heavy chain) of tetanus toxin activates protein kinase $C$ isoforms and phosphoproteins involved in signal transduction.

Biochem J 356: 97-103 
GONZALEZ-FORERO, D., R. R. de la CRUZ, J. M. DELGADO-GARCIA, F. J. ALVAREZ, A. M. PASTOR (2003): Functional alterations of cat abducens neuron after peripheral tetanus neurotoxin injection.

J Neurophysiol 89: 1878-1890

GORDON, V. M., S. H. LEPPLA (1994): Minireview: Proteolytic activation of bacterial toxins: role of bacterial and host cell proteases.

Infect Immun 62: 333-340

GRANGETTE, C., H. MÜLLER-ALOUF, D. GOUDERCOURT, M. C. GEOFFROY, M. TURNEER, et al. (2001): Mucosal immune responses and protection against tetanus toxin after intranasal immunization with recombinant Lactobacillus plantarum.

Infect Immun 69: 1547-1553

GRECO, J. B., E. SACRAMENTO, J. TAVARES-NETO (2001): Chronic ulcers and myasis as ports of entry for Clostridium tetani.

Braz J Infect Dis 5: 319-323

GROSSE-HERRENTHEY, A. (2004): Untersuchungen zu den Einflussfaktoren einer effizienten Bekämpfungsstrategie für Rinderbotulismus in Brasilien.

Diss med vet, Universität Leipzig

GUARDIOLA, A. A. M. TEIXEIRA, C. A. de SILVA, J. R. G. GRISOLIA, L. Z. PRATES, et al. (2000): Neonatal tetanus.

J Pediatr (RioJ) 76: 391-394

GUPTA, R. K., G. R. SIBER (1996): Use of in vitro vero cell assay and ELISA in the United States potency test of vaccines containing adsorbed diphtheria and tetanus toxoids.

Dev Biol Stand 86: 207-215

HÄSE, C., R. A. FINKELSTEIN (1993): Bacterial extracellular zinc-containing metalloproteases.

Microbiol Rev 57: 823-837

HALPERN, J. L., A. LOFTUS (1993): Characterization of the receptor-binding domain of tetanus toxin.

J Biol Chem 268: 11188-11192

HATHEWAY, C. L. (1990): Toxigenic clostridia.

Clin Microbiol Rev 3: 66-98

HELDENS, J. G., A. J. KERSTEN, M. W. WESTSTRATE, R. van den HOVEN (2001):

Duration of immunity induced by an adjuvanted and inactivated equine influenza, tetanus and equine herpesvirus 1 and 4 combination vaccine.

Vet Q 23: 210-217

HELTING, T. B., O. ZWISLER, H. WIEGANDT (1977): Structure of tetanus toxin. II. Toxin binding to ganglioside.

J Biol Chem 252: 194-198 
HENDRIKSEN, C. F. M., J. W. van der GUN, J. G. KREEFTENBERG (1989): Combined estimation of tetanus and diphteria antitoxin in human sera by the in vitro toxin-binding inhibition (ToBi) test.

J Biol Stand 17: 191-200

HENDRIKSEN, C. F. M., J. W. van der GUN, J. NAGEL, J. G. KREEFTENBERG (1991): The us eof the in vitro toxin binding inhibition (ToBi) test for the estimation of the potency of tetanus toxoid.

Biologicals, 19: 23-29

HENDRIKSEN, C. F. M., J. W. van der GUN, J. NAGEL, J. G. KREEFTENBERG (1988): The toxin binding inhibition test as a reliable in vitro alternative to the toxine neutralization test in mice or the estimation of tetanus antitoxin in human sera.

J Biol Stand 16: 287-297

HERREROS, J., G. LALLI, C. MONTECUCCO, G. SCHIAVO (2000): Tetanus toxin fragment $C$ binds to a protein present in neuronal cell lines and motoneurones.

J Neurochem 74: 1941-1950

HERREROS, J., T. NG, G. SCHIAVO (2001): Lipid rafts act as specialized domains for tetanus toxin binding and internalization into neurons.

Mol Biol Cell 12: 2947-2960

HOCHBERG (2005): Persönliche Mitteilung.

HOLLAND, R. E. (1990): Some infection causes of diarrhea in young farm animals.

Clin Microbiol Rev 3: 345-375

HOLMES, M. J., W. L. RYAN (1971): Amino acid analysis and molecular weight determination of tetanus toxin.

Infect Immun 3: 133-140

HUET, M. (1989): Rapid diagnostic methods. In: NISTICO, G., B. BIZZINI, B. BYTCHENKO, R. TRIAU (eds.) Eighth in conf tetanus.

Pythagora Press, Rom: 457-464

JAMES, K. (1990): Immunoserology of infectious diseases.

Clin Microbiol Rev 3: 132-152

JANSEN, B. C., P. C. KNOETZE (1979): The immune response of horses to tetanus toxoid. Onderstepoort J Vet Res 46: 211-216

JEFFCOTT, L. B. (1975): The transfer of passive immunity to the foals and its relation to immune status after birth.

J Reprod Fert 23: 727-733

JEFFCOTT, L. B. (1976): Übertragung der passiven Immunität beim Fohlen.

Prakt Tierarzt 57: 158-164 
KAUFMANN, L., J. C. HUMPHRIES (1958): Studies of the nutritional requirements of Clostridium tetani. I. A chemically defined medium.

Appl Microbiol 6: 311-315

KIM, J. W., F. W. SCHMIDT (1983): Zur Frage der Absorbtion von kolostralen Immunglobulinen durch das Kalb.

Dtsch Tierärztl 90: 283

KRAFT, W., U. M. DÜRR: Klinische Labordiagnostik in der Tiermedizin.

5. Aufl., Schattauer, Stuttgart

KROON, F. P., M. J. D. van TOL, C. M. JOL-van der ZIJDE, R. van FURTH, J. T. van DISSEL (1999): Immunglobulin G (IgG) subclass distribution and IgG1 avidity of antibodies in Human Immundeficiency Virus-infected individuals after revaccination with tetanus toxoid.

Clin Diagn Lab Immunol 6: 352-355

KRYZHANOVSKY, G. N. (1975): Tetanus: a polysystemic disease. In: Fondation Merieux (eds.): Proc fourth int conf tetanus.

Lyon: 189-199

LIN, C. S., W. A. HABIG, M. C. HARDEGREE (1985): Antibodies against the light chain of tetanus toxin in human sera.

Infect Immun 49: 111-115

LINDNER, K. E. (1971): Veterinärmikrobiologischer Kurs.

Fischer, Jena

LIU, I. K., S. L. BROWN, J. KUO, D. P. NEELEY, J. C. FEELEY (1982): Duration of maternally derived immunity to tetanus and response in newborn foals given tetanus antitoxin. Am J Vet Res 43: 2019-2022

LOCH, P. V. (2000): Kulturell biochemische und molekularbiochemische Untersuchungen sowie Pathogenitätsprüfung von Clostridium botulinum-Stämmen - Ein Betrag zur

Taxonomie

Diss med vet, Tierärztliche Hochschule, Hannover

LORENZ, R. J. (1996): Grundbegriffe der Biometrie.

4. Aufl., Fischer, Stuttgart

MADICO, G., G. SALAZAR, J. McDONALD, W. CHECKLEY, M. CALDERON, et al. (1996): Rates from tetanus protection and transplacental tetanus antibody transfer in pregnant women from different socioeconomic groups in Peru.

Clin Diagn Lab Immun, 3: 753-755

MAKOFF, A. J., S. P. BALLANTINE, A. E. SMALLWOOD, N. F. FAIRWEATHER (1989): Expression of tetanus toxin fragment $C$ in E. coli: its purification and potential use as a vaccine.

Biotechnology 7: 1043-1046 
MARCOTTE, H. und M. C. LAVOIE (1998): Oral microbial ecology and the role of salivary immuniglobulin A.

Microbiol Mol Biol Rev 62: 71-109

MAREK, J. und J. MOCSY (1951): Lehrbuch der klinischen Diagnostik der inneren Krankheiten der Haustiere.

4. Aufl., Fischer, Jena

MARTINEZ, R. J., S. C. RITTENBERG (1958) : Glucose dissimilation by Clostridium tetani.

J Bacteriol 2: 156-163

MARVAUD, J. C., U. EISEL, T. BINZ, H. NIEMANN, M. R. POPOFF (1998): TetR is a positive regulator of the tetanus toxin gene in Clostridium tetani and is homologous to BotR. Infect Immun 66: 5698-5702

MATOS, D. C. S., R. MARCONISTZ, P. H. CABELLO, R. A. GEORGINI, D. SAKAUCHI, et. al. (2002): Immunogenicity test of tetanus component in adsorbed vaccines by toxin binding inhibition test.

Mem Inst Oswaldo 97: 909-915

MATSUDA, M., D.-L. LEI, N. SUGIMOTO, K. OZUTSUMI, T. OKABE (1989): Isolation, purification, and characterization of fragment $\mathrm{B}$, the $\mathrm{NH}_{2}$-terminal half of the heavy chain of tetanus toxin.

Infect Immun 57: 3588-3593

MATZKIN, H., S. REGEV (1985) : Naturally aquired immunity to tetanus toxin in an isolated community.

Infect Immun 48: 267-268

MAYR, A., G. EISSNER, B. MAYR-BIBRACK (1993): Medizinische Mikrobiologie, Infektions- und Seuchenlehre.

Enke, Stuttgart

McDOUGAL, D. F. (1975): Immunglobulin metabolism in the neonatal foal.

J Reprod Fert, 23: 739-742

McGUIRE, T. C. and T. B. CRAWFORD (1972): Identification and quantitation of equine serum and secretory immunoglobulin A.

Infect Immun 6: 610-615

McGUIRE, T. C., T., B. CRAWFORD (1973): Passive immunity in the foal: measurement of immunglobulin classes and specific antibody.

Am J Vet Res, 34: 1299-1303

McGUIRE, T C., T. B. CRAWFORD, A. L. HALLOWELL, L. E. MACOMBER (1977):

Failure of colostral immunglobulin transfer as an explanation for most infections and death of neonatal foals.

J Am Vet Med Assoc, 170: 1302-1304 
McMAHON, H. T., P. FORAN, J. O. DOLLY, M. VERHAGE, V. M. WIEGANT, et al. (1992): Tetanus toxin and botulinum toxin type A and B inhibit glutamate, $\gamma$-aminobutyric acid, aspartate, and met-enkephalin release from synaptosomes. Clues to the locus of action. J Biol Chem 267: 21338-21343

MESNAGE, S., M. WEBER-LEVY, M. HAUSTANT, M. MOCK, A. FOUET (1999): Cell surface-exposed tetanus toxin fragment $C$ produced by recombinant Bacillus anthracis protects against tetanus toxin. Infect Immun 67: 4847-4850

METZ, B., C. HENDRIKSEN, W. JISKOOT, G. KERSTEN (2002): Review: Reduction of animal use in human vaccine quality control: opportunities and problems.

Vaccine 20: 2411-2430

MEYER, J. G, S. BELLWINKEL (1990): Labormedizin. Klinische Chemie, Immunologie, Hämatologie, Mikrobiologie.

4. Aufl., Deutscher Ärzte-Verlag, Köln

MILATOVIC, D., I. BRAVENY (1997): Infektionen. Praktische Hinweise zur antimikrobiellen Therapie und Diagnostik.

6. Aufl., Vieweg, München

MITSCHERLICH, E. und E. H. MARTH (1984): Microbial survival in the environment. Bacteria and rickettsiae important in human and animal Health.

Springer, Berlin: 134-138

MOLRINE, D. C., D. B. POLK, A. CIAMARRA, N. PHILLIPS, D. M. AMBROSINO (1995): Impaired human responses to tetanus toxoid in vitamin A-deficient SCID mice reconstituted with human peripheral blood lymphocytes.

Infect Immun 63: 2867-2872

MONTECUCCO, C. (1986): How do tetanus and botulinum toxin bind to neuronal membranes?

Trends Biochem Sci 11: 314-317

MULLINAX, R. L., E. A. GROSS, J. R. AMBERG, B. N. HAY, H. H. HOGREFE, et al. (1990): Identification of human antibody fragment clones specific for tetanus toxoid in a bacteriophage $\lambda$ immunoexpresion library.

Proc Natl Acad Sci 87: 8095-8099

MUMFORD, J. A., D. M. JESSETT, E. A. ROLLINSON, D. HANNANT, M. E. DRAPER (1994): Duration of protective efficacy of equine influenza immunostimulating complex/tetanus vaccines.

Vet Rec 134: 158-162

MURPHY, S. G., K. D. MILLER (1967): Tetanus toxin and antigenic derivativs. I. Purification of the biologically active monomer.

J Bact 94: 580-585 
MUTTER, M., J. GUBLER, A. SCHNIDER, L. WEIBEL, A. ZOLLIGER (2004): Eine seltene Ursache von Atemnot und Dysphagie.

Schweiz Med For 4: 423-425

NIBSC (2004): Tetanus toxoid adsorbed third international standard 2000.

NIBSC code: 98/552; Version 02 (letzter Zugriff am 19. 04. 2004)

NICOLAIER, A. (1884): Über infektiösen Tetanus.

Dtsch Med Wschr 10: 842-844

NIEMANN, H. (1991): Molecular biology of clostridial neurotoxins. In: J. Alouf and J. Freer (eds.): Sourcebook of bacterial protein toxins.

Academic press, London

O’BRIEN, M. A., M. A. HOLMES, W. P. DUFFUS (1992): In vitro production of specific antibody by equine peripheral blood mononuclear cells using tetanus toxoid as a recall antigen.

Res Vet Sci 53: 184-190

ODUSOTE, K. A., D. FEMI-PARESE (1975): Creatine phosphokinase (C. P. K.) and oxygen consumption (VO2) in the classification and assessment of tetanus. In: Fondation Merieux : Proc fourth int conf tetanus.

Lyon: 265-267

OIE (2000): Principles of validation of diagnostic assays for infection diseases. In: Manual standards for diagnostic test and vaccines. Chapter I.1.3.; $4^{\text {th }}$ edition 2000

http://www.oie.int/eng/normes/mmanual/A_00013.htm (letzter Zugriff am 14. 04. 2005)

OIE (2004): Quality management in veterinary testing laboratories. In: Manual of diagnostic tests and vaccines for terrestrial animals. $5^{\text {th }}$ edition 2004

http://oie.int/eng/normes/mmanual/A_00012.htm (letzter Zugriff am 27. 06. 2005)

OZUTSUMI, K., N. SUGIMOTO, M. MATSUDA (1985): Rapid, simplified method for production and purification of tetanus toxin.

Appl Env Microbiol 49: 939-943

PATTERSON-CURTIS, S. I., E. A. JOHNSON (1989): Regulation of neurotoxin and protease formation in Clostridium botulinum Okra B and Hall A by arginine.

Appl Env Microbiol 55: 1544-1548

PEREGO, M., J. A. HOCH, J. F. BARRETT (2004): Meeting Review: Functional genomics of gram positive microorganism.

J Bact 186: 903-909

PERRYMAN, L. E. (1981): Immunological management of young foals.

Comp Cont Educ 3: 223-228

PICKERING, J. W., T. B. MARTINS, M. C. SCHRODER, H. R. HILL (2002): Comparison of a multiplex flow cytometric assay with the enzyme-linked immunosorbent assay for the quantitation of antibodies to tetanus, diphteria, and Haemophilus influenzae type B.

Clin Diagn Lab Immun 9: 872-876 
PITZURRA, A. (1989): The history of tetanus. In: NISTICO, G., B. BIZZINI, B. BYTCHENKO, R. TRIAU (eds.): Eighth int conf tetanus.

Pythagora Press, Rom: 1-5

PITZURRA, L., E. BLASI, M. PULITI, F. BISTONI (1993): Toxic effects of tetanus toxin on GG2EE macrophages: prevention of gamma interferon-mediated upregulation of lysozymespecific mRNA levels.

Infect Immun 61: 3605-3610

PITZURRA, L., F. BISTONI, M. PITZURRA, L. BASTIANINI, S. PERITO, et al. (1983): Comparison of passive hemagglutination with turkey erythrocyte assay, enzyme-linked immunosorbent assay, and counterimmunelectrophoresis assay for serological evaluation of tetanus immunity.

J Clin Microbial 17: 432-435

POST, J. B. (1978): Report of operational test II (OT II). Hypodermic injector apparatus, Veterinary medicine. In: SEIFERT, H. S. H. und H. BÖHNEL (1995): Handbuch der bakteriellen Infektionen bei Tieren.

Fischer, Jena

QUETGLAS, S., C. IBORRA, N. SASAKAWA, L. de HARO, K. KUMAKURA, et al. (2002): Calmodulin and lipid binding to synaptobrevin regulates calcium-dependent exocytosis.

Eur Mol Biol Org J 21: 3970-3979

ROBERT-KOCH-INSTITUT (2002): Tetanus - Ratgeber für Ärzte.

Epidem Bull, 27, Berlin

ROITT, I. M., J. BROSTOFF, D. K. MALE (2001): Immunology.

$6^{\text {th }}$ ed., Mosby, Edinburgh

ROMANOS, M. A., A. J. MAKOFF, N. F. FAIRWEATHER, K. M. BEESLEY, D. E.

SLATER, et al. (1991): Expression of tetanus fragment $C$ in yeast: gene synthesis is required to elimate fortuitous polyadenylation sites in AT-rich DNA.

Nucl Acids Res 19: 1461-1467

ROSSDALE, P. D., J. SCARNELL (1961): Immunization of the new-borne foal against tetanus.

Vet Rec 73: 184-185

ROSSKOPF, U. (2004): Ersatz des in vivo Neutralisationstests bei der Wirksamkeitsprüfung von Tetanusimpfstoffen ad us vet. im Rahmen der Zulassung.

http://www.zet.or.at/kongress/Linz2004/abstracts/rosskopf.html (letzter Zugriff am 09. 12. 2005)

ROSSKOPF-STREICHER, U., P. VOLKERS, K. NOESKE, E. WERNER (2004): Quality assurance of $C$. perfringens epsilon toxoid vaccines-ELISA versus mouse neutralization test. ALTEX 21: 65-69 
ROSSKOPF-STREICHER, U., P. VOLKERS, E. WERNER (2003): Control of Clostridium perfringens vaccines using an indirect competitive ELISA for the epsilon toxin component. Pharmeuropa Bio 2: 91-96

ROWE, J., C. MACAUBAS, T. M. MONGER, B. J. HOLT, J. HARWEY, et al. (2000): Antigen-specific responses to diphteria-tetanus-acellular pertussis vaccine in human infants are initially Th2 polarized.

Infect Immun 68: 3873-3877

SANADA, I., S. NISHIDA (1965): Isolation of Clostridium tetani from soil. J Bact 89: 626-629

SCHATZ, D. T. ELLIS, E. OTTENDORFER, E. JODOIN, D. BARRETT, et al. (1998):

Aging and the immune response to tetanus toxoid: diminished frequency and level of cellular immune reactivity to antigenic stimulation.

Clin Diagn Lab Immunol 5: 894-896

SCHAUER, U., F. STEMBERG, C. H. L. RIEGER, W. BÜTTNER, M. BORTE, et al. (2003): Levels of antibodies specific to tetanus toxoid, Haemophilus influenzae type B, and pneumococcal capsular polysaccharide in healthy children and adults.

Clin Diagn Lab Immunol 10: 202-207

SCHIAVO, G., F. BENFENATI, B. POULAIN, O. ROSETTO, D. L. P. POLVERINO, et al. (1992): Tetanus and botulinum-B neurotoxins block neurotransmitter release by proteolytic cleavage of synaptobrevin.

Nature (London) 359: 832-835

SCHIAVO, G., G. FERRARI, O. ROSETTO, C. MONTECUCCO (1991): Tetanus toxin receptor. Specific cross linking of tetanus toxin to a protein of NGF-differntiated PC 12 cells. Fed Eur Biochem Soc Lett 290: 227-230

SCHIAVO, G., M. MATTEOLI, C. MONTECUCCO (2000): Neurotoxins affecting neuroexocytosis.

Physiol Rev 80: 717-766

SCHIAVO, G., E. PAPINI, G. GENNA, C. MONTECUCCO (1990): An intact interchain disulfide bond is required for the neurotoxicity of tetanus toxin.

Infect Immun 58: 4136-4141

SCHIAVO, G., B. POULAIN, O. ROSETTO, F. BENFENATI, L. TAUC, et al. (1992): Tetanus toxin is a zinc protein and its inhibition of neurotransmitter release and protease activity depend on zinc.

Eur Mol Biol Org J 11: 3577-3538

SCHLEGEL, H. G. (1981): Allgemeine Mikrobiologie.

5. Aufl; Thieme, Stuttgart

SCHWENDEMAN, S. P., H. R. COSTATINO, R. K. GUPTA, G. R. SIBER, A. M.

KLIBANOV, et al. (1995): Stabilization of tetanus and diphtheria toxoids against moistureinduced aggregation.

Proc Natl Acad Sci 92: 11234-11238 
SEDGWICK, A. K., M. BALLOW, K. SPARKS, R. TILTON (1983): Rapid quantitative microenzyme-linked immunosorbent assay for tetanus antibodies.

J Clin Microbiol 18: 104-109

SEIFERT, H. S. H. und H. BÖHNEL: Handbuch der bakteriellen Infektionen bei Tieren.

2. Aufl.; Fischer, Jena

SHEPPARD, A. J., D. CUSSELL, M. HUGHES (1984): Production and characterization of monoclonal antibodies to tetanus toxin.

Infect Immun 43: 710-714

SHI, Z., M. ZENG, G. YANG, F. SIEGEL, L. J. CHAIN, et al. (2001): Protection against tetanus by needle-free inoculation of Adenovirus vectored nasal and epicutanous vaccines. J Virol 75: 11474-11482

SHIMIZU, T., K. OHTANI, H. HIRAKAWA, K. OHSHIMA, A. YAMASHITA, et al. (2002): Complete genome sequence of Clostridium perfringens, an anaerobic flesh-eater. Proc Natl Acad Sci 99: 996-1001

SINGH, M., X.-M. LI, H. WANG, J. P. McGEE, T. ZAMB, et al. (1997): Immunogenicity and protection in small-animal modells with controled-release tetanus toxoid microparticles as a single-dose vaccine.

Infect Immun 65: 1716-1721

SMITH, K. L., L. A. MUIR, L. C. FERGUSON, H. R. CONRAD (1971): Selective transport of IgG into the mammary gland: role of oestrogen and progesteron.

J Dia Sci 54, 1886-1894

SOTTIURAI, V. und A. A. FEDINEC (1975): Ultrastructure of nephron in tetanus intoxication. In: Foundation Merieux (eds): Proc fourth int conf tetanus.

Lyon: 211-218

SZABO, E. A., J. M. PEMBERTON, P. M. DESMARCHELIER (1993): Detection of the genus encoding botulinum neurotoxin types $\mathrm{A}$ to $\mathrm{E}$ by polymerase chain reaction.

Appl Envirom Microbiol 59: 3011-3020

TANGNEY, M., W. J. MITCHELL (2004): Clostridium tetani encodes a phosphocarrier protein, HPr.

Microbiology 50: 525-526

THEIN, P. (1983): Zur Mutterschutzimpfung beim Pferd.

Tierärztl Umsch 38, 239-250

THEIN, P. (2003): Wie impft man Fohlen richtig?

Tierärztl Umsch 38, 783-790

TIZARD, I. R. (2004): Veterinary Immunology.

$7^{\text {th }}$ ed., Saunders, Philadelphia 
TOGO, T., J. M. ALDERTON, R. A. STEINHARDT (2003): Long-term potentation of exocytosis and cell membrane repair in fibroblasts.

Mol Biol Cell 14: 93-106

TREGONING, J. S., P. NIXON, H. KURODA, Z. SVAB, S. CLARE, et al. (2003):

Expression of tetanus toxin fragment $\mathrm{C}$ in tobacco chloroplasts.

Nucl Acid Res 31: 1174-1179

TRISKATIS, A.-L. (2004): Semiquantitative Bestimmung von Antikörpern gegen Rhodococcus equi in Serum und Kolostrum bei Stuten und Fohlen mittels ELISA und Vergleich mit Befunden der Lungenuntersuchung.

Diss med vet, Tierärztliche Hochschule, Hannover

TSUZUKI, K., N. YOKOSAWA, B. SYOTO, I. OHISHI, N. FUJII, et al. (1988):

Establishment of a monoclonal antibody recognizing an antigenic site common to Clostridium botulinum type $\mathrm{B}, \mathrm{C}_{1}, \mathrm{D}$, and E-toxins and tetanus toxin.

Infect Immun 56: 898-902

ULLRICH, K., W. JAKSCH, E. GLAWISCHNIG (1985): Grundriss der speziellen Pathologie und Therapie der Haustiere.

Enke, Stuttgart

UMESAKI, Y., H. SETOYAMA, S. MATSUMOTO, A. IMAOKA, K. ITOH (1999):

Differential roles of segmented filmentous bacteria and clostridia in developement of the intestinal immune system.

Infect Immun 67: 3504-3511

UNITED STATES DEPARTEMENT OF AGRICULTURE (1992): SAM 216: Supplemental assay for testing the potency of commercial equine tetanus antitoxin.

Ames

UNITED STATES DEPARTEMENT OF AGRICULTURE (1992): SAM 217: Supplemental assay method for potency testing of tetanus toxoid by ELISA.

Ames

VAKIL, B. J., , R. M.BHATT, K. B. BHISE, N. J. DALAL, B. I. SANGVAVI (1975): Serum creatine phosphokinase in tetanus. In: Fondation Merieux (eds.): Proc fourth int conf tetanus. Lyon: 255-264

VERDERIO, C., S. COCO, A. BACCI, O. ROSETTO, P. de CAMILLI, et al. (1999): Tetanus toxin blocks the exocytosis of synaptic vesicles clustered at synapses but not of synaptic vesicles in isolated axons.

J Neurosci 19: 6723-6732

VERONESI, R., A. CORREIA, H. FERREIRA, C. COSTA, R. FOCACCIA, et al. (1975):

Naturally aquired tetanus immunity: further evidences in human and animals. In: Fondation

Merieux (eds.): Proc fourth int conf tetanus.

Lyon: 613-626 
VOLK, W. A., B. BIZZINI, R. M. SNYDER, E. BERNHARD, R. R. WAGNER (1984):

Neutralization of tetanus toxin by distinct monoclonal antibodies binding to multiple epitopes on the toxin molecule.

Infect Immun 45: 604-609

WATERS, M., A. SAVOIE, H. S. GARMORY, D. BUESCHEL, M. R. POPOFF, et al. (2003): Genotyping and phenotyping of beta 2-toxigenic Clostridium perfringens fecal isolates associated with gastrointestinal diseases in piglets.

J Clin Microbiol 41: 3584-3591

WECKER, E. (1990): Immunologie kurzgefasst.

BI-Wissenschaftsverlag, Mannheim

WEGE, A. K. (2004): Expression und Charakterisierung dreier IgG-Isotypen des Pferdes und Entwicklung einens monoklonalen Nachweisantikörpers für das equine IgG2.

Diss med vet, Tierärztliche Hochschule, Hannover

WELLHÖNER; H. H., G. ERDMANN, H. WIEGAND (1975): Intraaxonal and extraaxonal ascent of tetanus toxin. In: Foundation Merieux (eds): Proc fourth int conf tetanus.

Lyon: 159-161

WEN, Q., K. MIYAMOTO, B. A. McCLANE (2003): Developement of a duplex PCR genotyping assay for distinguishing Clostridium perfringens type A isolates carrying chromosomal enterotoxin (сре) genes from those carrying plasmid-borne enterotoxin (сре) genes.

J Clin Microbiol 41: 1494-1498

WHITFORD, H. W.: The evaluation of jet injection for use in veterinary medicine. In: SEIFERT, H. S. H. und H. BÖHNEL (1995): Handbuch der bakteriellen Infektionen bei Tieren.

Fischer, Jena

WHO (1993): Global programme for vaccines and immunization. Expanded programme on Immunization. The immunological basis for immunization series. Modul 3: Tetanus.

World Health Organization, Geneva; WHO/EPV/GEN/93.13

WILLIAMSON, L. C., K. E. BATEMAN, J. C. M. CLIFFORD, E. A. NEALE (1999):

Neuronal sensitivity to tetanus toxin requires gangliosides.

J Biol Chem 274: 25173-25180

WILKINS, C. A., M. B. RICHTER, W. B. HOBBS, M. WHITCOMB, N. BERGH et al. (1988): Occurrence of Clostridium tetani in soil and horses.

S Afr Med J 73: 718-720

WILSON, K., K. H. GOULDING (1991): Enzymgebundener Immunoassay ELISA. In: Methoden der Biochemie.

3. Aufl., Thieme, Stuttgart 
WILSON, W. D., J. E. MIHALYI, S. HUSSEY, D. P. LUNN (2001): Passive transfer of maternal immunglobulin isotype antibodies against tetanus and influenza and their effect on the response of foals to vaccination.

Equine Vet J 33: 644-650

WINSNES, R., M. ORSTVEDT, I. HERON, B. MOGSTER (1989): The potency determination of human tetanus immunoglobulin by various modifications of enzyme-linked immunosorbent assay, by toxin neutralization test in mice and by counterimmunoelectrophoresis. In: NISTICO, G., B. BIZZINI, B. BYTCHENKO, R. TRIAU (eds.) Eighth int conf tetanus.

Pythagora Press, Rom: 312-319

WINTERHOFF, C. (2000): Paratuberculose-Diagnostik in Milch: Erreger- und Antikörpernachweis mittels PCR und ELISA.

Diss med vet, Tierärztliche Hochschule, Hannover

WOO, P. C. Y., H.-W. TSOI, L.-P. WONG, H. C. H. LEUNG, K.-Y. YUEN (1999):

Antibodies modulate vaccine-induced humoral immune response.

Clin Diagn Lab Immunol 6: 832-837

WU, H.-C., C.-T. YEH, Y.-L. HUANG, L.-J. TARN, C.-C. LUNG (2001): Characterization of neutralizing antibodies and identification of neutralizing epitope mimics on the Clostridium botulinum neurotoxin type A.

Appl Env Microbiol 67: 3201-3207

YAMAMOTO, M., N. WADA, Y. KITABATAKE, D. WATANABE, M. ANZAI, et al. (2003): Reversible Suppression of glutamergic neurotransmission of cerebellar granule cells in vivo by genetically manipulated expression of tetanus neurotoxin.

J Neurosci 23: 6759-6767 


\section{Geräte, Chemikalien und Puffer}

Abdeckklebefolie (Nunc)

Duvaxyn IE-T Plus ${ }^{\circledR}$ (Fort Dodge)

Einwegspritzen (Braun)

Eisessig (Merck)

Equilis Tetanusvaccine ${ }^{\circledR}$ (Intervet)

$\mathrm{H}_{2} \mathrm{O}_{2}$ (Merck)

$\mathrm{H}_{2} \mathrm{SO}_{4}, 98$ \% (Merck)

HRP-mark. Kaninchen anti-equine-IgG (Dianova)

Hyperimmunserum-Standard 1000 IE (WDT)

Inkubationschrank $37^{\circ} \mathrm{C}$ (Memmert)

Kanülen (Braun)

$\mathrm{KCl}$ (Merck)

$\mathrm{KH}_{2} \mathrm{PO}_{4}$ (Merck)

Kryoröhrchen (Greiner)

Mehrkanalpipette (Biohit)

Mikrotiterplatten „Microlon 600“ (Greiner)

Mikrotiterplattenreader; kompatible Gerätesoftware (Tecam Instruments)

$\mathrm{NaCl}$ (Merck)

$\mathrm{Na}_{2} \mathrm{CO}_{3}$ (Merck)

$\mathrm{NaHCO}_{3}$ (Merck)

$\mathrm{Na}_{2} \mathrm{HPO}_{4}$ × $2 \mathrm{H}_{2} \mathrm{O}$ (Merck)

OPD (Sigma)

Paramectin ${ }^{\circledR}$ (IDT)

Reagenzreservoire (Eppendorf)

Reaktionsgefäße 1,5 ml (Eppendorf)

Renin (Roth)

Serum-, EDTA-, Heparin-, Citratröhrchen (Kabe)

Spritzenfilter 0,2 $\mu \mathrm{m}$ (Sartorius)

Sterilfiltrationseinheiten 1,5 I (Nalgene)

Tetanustoxin (Sigma)

Tetanustoxoidstandard 150 LF/ml (RIVM)

Tween ${ }^{\circledR} 20$ (Merck) 
Wasserbad (B. Braun)

Zentrifuge „Biofuge“ (Hereus)

Zitronensäure-Monohydrat (Merck)

Citrat-Phosphatpuffer Stammlösung

10,63 g Zitronensäure-Monohydrat

18,16 g $\quad \mathrm{Na}_{2} \mathrm{HPO}_{4} \times 2 \mathrm{H}_{2} \mathrm{O}$

ad $\quad 1000 \mathrm{ml}$ Aquadest; $\mathrm{pH}$ 5,0 äquillibrieren; sterilfiltrieren $(0,2 \mu \mathrm{m})$

Citrat-Phosphatpuffer Gebrauchslösung

$12 \mathrm{ml} \quad$ Citrat-Phosphatpuffer Stammlösung

$12 \mu \mathrm{l} \quad \mathrm{H}_{2} \mathrm{O}_{2}$

1 Tablette OPD

Karbonat-Bicarbonatpuffer $\mathrm{pH}$ 9,5

$39,3 \mathrm{ml} \mathrm{0,1} \mathrm{M} \mathrm{Na}_{2} \mathrm{CO}_{3}$

$60,0 \mathrm{ml} \mathrm{0,1} \mathrm{M} \mathrm{NaHCO}_{3}$

pH 9,6 mit 0,1 M Essigsäure

PBS; Stammlösung

$\begin{array}{rl}16 \mathrm{~g} & \mathrm{NaCl} \\ 4 \mathrm{~g} & \mathrm{KCl} \\ 28,8 \mathrm{~g} & \mathrm{Na}_{2} \mathrm{HPO}_{4} \\ 4,8 \mathrm{~g} & \mathrm{KH}_{2} \mathrm{PO}_{4}\end{array}$

ad 1000 ml Aquadest; pH 7,2 mit $2 \mathrm{~N} \mathrm{HCl}$

PBS; Gebrauchslösung 1:40 mit Aquadest verdünnen; sterilfiltrieren (0,2 $\mu \mathrm{m})$

$0,5 \times$ PBS $+0,1 \%$ Tween $20^{\circledR}$ in Aquadest

$2 \mathrm{M} \mathrm{H}_{2} \mathrm{SO}_{4}$ in Aquadest 


\section{Abbildungsverzeichnis}

Abb.1: $\quad$ Biochemisches Profil von C. tetani

Abb. 2: $\quad$ Standardkurve bei Verwendung von 1 Lf/ml Tetanustoxoid zum Coaten

Abb. 3: $\quad$ Ermittlung der optimalen Serumverdünnung

Abb. 4: $\quad$ Boxplot der Serumtiter bei nicht immunisierten Jährlingen

Abb. 5: Histogramm der negativen, grenzwertigen und seropositiven Titer bei immunisierten Stuten

Abb. 6: $\quad$ Verlauf des maternalen anti-Tetanus-IgG-Gehaltes in Seren neugeborener Fohlen

Abb. 7: Boxplot des maternalen anti-Tetanus-IgG-Gehalte in Seren neugeborener Fohlen

Abb. 8: $\quad$ Tetanus-Antitoxin-Titerverlauf bei Jungstuten nach Tetanusgrundimmunisierung

Abb. 9: $\quad$ Boxplot des tetanusspezifischen IgG-Gehaltes von Jungstuten nach Tetanusgrundimmunisierung

Abb. 10: Titerverlauf von tetanusspezifischem IgG in Seren von Saugfohlen nach erster und zweiter Grundimmunisierung

Abb. 11: Boxplot des Tetanus-IgG-Gehaltes in Seren grundimmunisierter Saugfohlen

Abb. 12: Tetanus-Antitoxinspiegel in Seren grundimmunisierter und nicht grundimmunisierter Saugfohlen

Abb. 13: $\quad$ Titerverlauf bei gut immunisierten Altstuten nach Boosterung

Abb. 14: Boxplot der tetanusspezifischen Antitoxintiter in Seren von gut immunisierten Altstuten nach Boosterung

Abb. 15: Anti-Tetanus-IgG-Gehalt in Kolostrum und Milch

Abb. 16: Boxplot der anti-Tetanus-IgG-Gehalte in Kolostrum und Milch

Abb. 17: Vergleich der tetanusspezifischen IgG-Gehalte in Kolostrum/Milch mit Fohlenseren

Abb. 18: Anti-Tetanus-IgG-Gehalte in Kolostrum/Milch, Stuten- und Fohlenseren Abb. 19: Tetanusspezifischer Antitoxintiter bei einem an Tetanus erkrankten Fohlen 


\section{Tabellenverzeichnis}

Tab. 1: $\quad$ Ökologische Parameter der vegetativen Zellen und Sporen von C. tetani

Tab. 2: $\quad$ Nomenklaturen der Immunglobuliklassen des Pferdes

Tab. 3: $\quad$ Impfschemata für Menschen und Pferde

Tab. 4: Vakzinierungsschema

Tab. 5: $\quad$ Ermittlung der optimalen Serumverdünnung

Tab. 6: Darstellung des Intraassayvarianzkoeffizienten

Tab. 7: $\quad$ Berechnung des Schwellenwertes und des Cut off

Tab. 8: $\quad$ Vergleich von Validierungsparametern des eigenen Tests mit kommer-ziellen Anbietern

Tab. 9: $\quad$ Kinetik der tetanusspezifischen Antikörperbildung bei Saugfohlen und Jährlingen 


\section{Danksagung}

- Herrn Prof. Dr. Dr. Helge Böhnel sowie Herrn Dr. Frank Gessler aus dem Institut für Tropentierhygiene der Universität Göttingen für die Bereitstellung des Themas, die fachliche Unterstützung und Begutachtung der Arbeit

- Prof. Dr. Dr. C. Czerny für die fachlichen Hinweise und die Begutachtung der Dissertation

- Herrn Prof. Dr. Hans-Peter Schmauder im Namen der Geschäftsleitung des fzmb Bad Langensalza für die Bereitstellung der Arbeitsmaterialien, Geräte und Räumlichkeiten - meinem Kollegen, dem Oberarzt der Großtierklinik des fzmb, Dr. Dirk Barnewitz für die fachliche Beratung, die Bereitstellung der Impfstoffe, sowie die Planung, Koordinierung und Durchführung der Probenahmen

- Anke Sendig-Jahn und allen ihren Mitarbeitern des Haflingergestüts Meura für die Bereitstellung der Pferde, ihre Kooperativität und der immer herzlichen Gastfreundschaft bei unseren Besuchen

- Kerstin Ehrlich und Kathrin Unger vom Gestüt Meura für ihre Unterstützung bei den Blutungen und der Entnahme der Milchproben

- Gestütstierarzt Dr. Dietmar Leib für die Durchführung der Vakzinierungen

- Dr. P. Miethe, Fa. Senova, Jena für die Bereitstellung des Toxoidstandards

- meinen Kollegen der Abt. Biotechnologie, insbesondere Frau Dipl.-Chem. Kerstin Schlufter für ihre Unterstützung in der letzten Phase der Dissertation

- besonderer Dank an meine Freunde und Kollegen, vor allem der Großtierklinik des fzmb, für das gute Arbeitsklima, die großzügige Zusammenarbeit, Kaffee, Kuchen und Zuspruch: Marlen Fallak, Michaela Nonn, Mario Beck, TÄ Kristin Zänker, TÄ Dr. Carmen Klein, TA Dr. Christoph Werner, TÄ Sabine Kussmann, Anja Krey, Carolin Burkhardt, TÄ Nancy Schmieder,

- Dipl. Ing. Holger Plettenberg und Dipl. Ing. Stefan Luck aus der Abt. Geräteentwicklung des fzmb, für ihre Hilfe bei Computerproblemen und der statistischen Auswertung

- Aileen Dachrodt für die Korrektur von Rechtschreibung und Grammatik

und natürlich

- meiner Familie für ihre Unterstützung 
Anke Jutta Mülverstedt

geb. am 17. 01. 1971 in Mühlhausen/Thüringen

verheiratet, zwei Kinder (1998, 2003)

Schulbildung: $\quad 1977$ - 1987 Oberschule in Hüpstedt/Thüringen

1987 - 1990 Erweiterte Oberschule; Abitur in Gotha

Berufsausbildung: $\quad 1990$ - 1992 Veterinärmedizinisch-technische Assistentin in Beichlingen/Thüringen

Studium: $\quad 1992-1998$ Diplomstudium Biologie, Friedrich-Schiller-Universität Jena; Hauptfach Mikrobiologie (NF: Biochemie, Med. Mikrobiologie) Diplom am Institut für Medizinische Mikrobiologie der FSU Jena bei Prof. Dr. med. E. Straube/Prof. Dr. med. W. Pfister

Berufstätigkeit - Ausbildungsjahr 1997/1998 Lehrkraft für Physikalisch-Chemische Arbeitsmethoden und Umweltanalytik an der Höheren Berufsfachschule in Mühlhausen/Thüringen

- Seit November 1999 wissenschaftliche Mitarbeiterin im Forschungszentrum für Medizintechnik und Biotechnologie Bad Langensalza/Thüringen

- seit Juni 2003 Promotion am Institut für Pflanzenbau und Tierhygiene in den Tropen und Subtropen, Georg-August-Universität Göttingen bei Prof. Dr. Dr. H. Böhnel

- seit Januar 2005 Laborleiterin Mikrobiologische Trinkwasseruntersuchung im Betriebsteil Erfurt des fzmb 